\title{
The Role of the Cryosphere in Source-to-Sink Systems
}

$2^{\text {nd }}$ REVISED Manuscript for submission to Earth Science Reviews,

Special issue on Source to Sink Systems

John M. Jaeger $^{1}$ and Michele Koppes ${ }^{2}$

${ }^{1}$ Dept. of Geological Sciences

University of Florida

Gainesville FL, 32611-2120

USA

${ }^{2}$ Dept. of Geography

University of British Columbia

1984 West Mall

Vancouver, BC V6T1Z2

Canada

Corresponding author: jmjaeger@ufl.edu 


\section{Abstract}

2 Glacial erosion and sediment production are of interest to diverse scientific communities

3 concerned with the interaction of climatic, tectonic and surface processes that influence the

4 evolution of orogens and with the climatic signals archived in glacigenic strata. We review the

5 current state of knowledge on the generation, transfer, and accumulation of glacigenic sediment

6 from land to sea. We draw from geomorphology, marine geology, geochronology, numerical

7 modeling of surface processes and landscape evolution, and experimental and field observations

8 of glacier erosion and deposition, and the interaction of ice with its bed and the ocean boundary.

9 Our primary goal is to examine glacial systems using a holistic source-to-sink approach, with a

10 focus on describing a) how glacial motion produces sediment, b) how the sediments (sink) record

11 the dynamic nature of glacial systems under different climatic (thermal) regimes, c) the

12 challenges in using the sedimentary record to interpret these dynamics in space and time, and d)

13 the approaches still needed to further our understanding of how ice and associated sediment

14 fluxes respond to climatic and other perturbations. The dynamic state of ice, i.e., the ice flux and

15 ice extent, is defined differently between the source and sink communities, reflecting the

16 challenges of establishing a stratigraphic signal that volumetrically constrains glacigenic

17 sediment production as a function of the ice response to climate. Advances in marine geophysics

18 have greatly assisted our understanding of mass transfer pathways and of former ice extents as a

19 measure of ice dynamics, and have identified the primary depocenters and key lithofacies of

20 glacial sinks. Sediment fluxes associated with the dynamic state of the ice are best constrained

21 where sediment volumes derived from key lithofacies and seismic reflection isopachs can be

22 temporally partitioned, of which there are few examples, rather than from discrete point

23 measures of sediment flux that are subject to sediment transfer biases. Forward numerical 
24 modeling of sediment fluxes as a function of ice dynamics agree with observational data at the

25 continental-margin scale, but finer time/space scale ice-dynamic models do not yet recreate

26 observed ice extent or flowpaths. Future source-to-sink work in glaciated systems should focus

27 on refining empirical relationships between ice velocity and sediment production, and expand the

28 application of existing methods to develop sediment volumes and fluxes in known depocenters

29 of former and modern ice streams.

30

31 Keywords:

32 Ice dynamics

33 Glacial history

34 Glacigenic sediment

35 Glacimarine sedimentary processes

36 High-latitude continental margins

37 Quaternary stratigraphy

38 


\section{Introduction}

A principal goal of examining a sediment routing system is to understand how it responds

41 to, and preserves a record of, the dynamic processes that drive sediment production and transfer.

42 This is especially important in settings where the principal geomorphic agent that produced the

43 sediment is no longer present or challenging to work with under modern conditions. Global

44 climate during the Quaternary Era is distinguished by the periodic intensification of glacial

45 conditions on land and along continental margins (Larsen et al., 1994; McKay et al., 2009;

46 Lourens et al., 2010; Jakobsson et al., 2014). The onset of widespread glaciation is viewed as

47 responsible for the global increase in sedimentation that coincided with a change to a cooler and

48 more variable climate beginning 2-4 Myr ago, creating clastic wedges on continental margins

49 that are up to $5 \mathrm{~km}$ thick (Eyles et al., 1991; Vorren et al., 1991; Eidvin et al., 1993; Faleide et

50 al., 1996; Elverhoi et al., 1998a; Solheim et al., 1998; Laberg et al., 2010). The majority of mid-

51 and high-latitude landscapes, from the land to the deep sea, reflect extensive Quaternary glacial

52 influence (Bingham et al., 2010; Champagnac et al., 2014; Pedersen et al., 2014b), including

53 large-scale depositional and erosional landforms such as voluminous loess and paraglacial

54 terrestrial deposits (e.g., Derbyshire, 2003), scablands carved by meltwater (e.g., Hanson et al.,

55 2012), ice-gouged seafloors (e.g., Dowdeswell and Bamber, 2007; Dowdeswell et al., 2007;

56 Batchelor et al., 2011; Cofaigh et al., 2012; Dowdeswell et al., 2014), and thick accumulations of

57 glacimarine sediments both on land and in the ocean (e.g., Eyles et al., 1991; Dahlgren et al.,

58 2005; Laberg et al., 2010). Glacial source-to-sink systems consequently are a primary archive of

59 past and present global change.

Glacial erosion and sediment production are of interest to a wide variety of scientific

61 communities concerned with the interaction of climatic, tectonic and surface processes that 
62 influence the evolution of mountain ranges, and with the interpretation of climatic and tectonic

63 signals archived in sediments produced by the ice. Glaciated landscapes were one of the first

64 depositional environments where sedimentary signals such as glacial drift, erratics, and moraines

65 were formally interpreted to describe a series of dynamic ice processes that were either absent

66 from or significantly reduced in scale in the current landscape. Since the mid-1800s, glacial

67 chronologies have been developed for many regions where the ice was once more extensive

68 (e.g., Agassiz, 1840; Lyell, 1840; Chorley, 1973), and past global ice volumes have been

69 estimated from the oxygen isotopic record preserved in marine sediments (Imbrie et al., 1984;

70 Raymo et al., 2007). While the marine isotope stage (MIS) records have provided broad

71 constraints on the timing of recent and Quaternary glaciations (e.g., Lisiecki and Raymo, 2007;

72 Kawamura et al., 2008), less is known about the internal dynamics of former glaciers and ice

73 sheets and their relationship to climate. Over a century later, we are still grappling with how to

74 link dynamic glacial processes with their sedimentary and geomorphic products.

75 Landscape modification by ice is profound. Our ability to evaluate how glaciers and

76 glacial erosion shape landscapes, produce sedimentary signals, and reflect climatic (or tectonic)

77 variability is still limited by a dearth of information about what controls the rate of glacial

78 erosion and sediment production. Climate drives a glacier's mass balance, which in turn

79 determines the ice flux that erodes the landscape (e.g., Benn and Evans, 2010; Cuffey and

80 Paterson, 2010). Terrestrial and marine subglacial and proglacial environments are among the

81 most logistically challenging environments to work in, hampering our ability to develop first-

82 order relationships between ice dynamics and sediment production. Moreover, generating a

83 chronology on the timing and magnitude of glacial erosion and deposition has always been

84 challenging (e.g., Balco and Rovey, 2010; Fastook and Hughes, 2013; Ingolfsson and Landvik, 
85 2013; Cofaigh et al., 2014), often requiring multiple approaches (Livingstone et al., 2012;

86 Fastook and Hughes, 2013), but has recently become more robust with evolving

87 geochronometric techniques (e.g., Rosenheim et al., 2008; Balco and Rovey, 2010; Simon et al., 88 2012).

89 Glacial source-to-sink systems are unique in that ice, the primary erosional agent, can

90 move through almost the entire length of a system, from the high mountains to the continental

91 shelf edge, during one climatic period and then be entirely absent during others (Fig. 1).

92 Moreover, ice responds to climate by adjusting its spatial extent and its internal flow dynamics

93 (e.g., Raymond, 1987), which vary in space and time its capacity to do geomorphic work and

94 produce sediment. In addition, the potential for ice to recycle its sedimentary record as it

95 advances and retreats through the transfer zone results in an incomplete record of dynamics

96 closest to the ice, and an integrated record beyond the last ice maximum extent (Fig. 1; e.g.,

97 Faleide et al., 1996; Hebbeln et al., 1998; Anderson, 1999; Cofaigh et al., 2002; Hemming,

98 2004). The most complete record often exists in the marine realm, but this setting is subject to its

99 own internal dynamics that mute terrestrial ice signals, and often results in a record that is

100 overprinted by oceanographic processes and tectonic preconditioning of the basin (Figs. 1 and 2;

101 Cofaigh et al., 2002; Nygård et al., 2005; Reece et al., 2011; Andrews and Vogt, 2014; Walton et

102 al., 2014; Romans et al., this volume). As such, the sedimentary record associated with both ice

103 flux as well as ice sheet growth and decay can reflect both autogenic and allogenic forcing,

104 complicating our ability to directly relate ice dynamics and sediment production to any particular

105 climatic forcing.

106 Yet, given these limitations, we still are able to develop general conceptual and

107 quantitative models of the role of ice in the production of a sedimentary signal (Figs. 1 and 2). 
108 On orbital time scales, the growth and decay of ice has a global signal (Raymo et al., 2007;

109 Lourens et al., 2010; Patterson et al., 2014). At higher temporal resolutions, the terrestrial and

110 marine stratigraphic records of glacier and ice sheet dynamics contain a combination of local and

111 regional processes and influences, including the climate, thermal regime of the ice, subglacial

112 hydrology, bedrock lithology, drainage basin topography and size, oceanographic setting, sea

113 level, and tectonic conditioning. For instance, both sediment and meltwater production vary by

114 orders of magnitude over time (e.g., seasonally), as a consequence of the thermal regime of the

115 ice (i.e., temperate versus polar glacial systems), and between tectonically active and quiescent

116 margins (Koppes and Montgomery, 2009; Koppes et al., 2015). Still, across all thermal and

117 tectonic regimes there are consistent geomorphic and sedimentary signatures that reflect this

118 glacigenic influence, including tills, glacimarine diamicts, ice-rafted debris, moraines, megascale

119 glacial lineations, and grounding zone wedges (e.g., Carlson et al., 1977; Licht et al., 1999; St

120 John and Krissek, 1999; Stokes and Clark, 2001; Anderson et al., 2002; Cofaigh et al., 2007;

121 Ottesen et al., 2008b; Hambrey and Glasser, 2012; Livingstone et al., 2012; Ingólfsson and

122 Landvik, 2013; Batchelor and Dowdeswell, 2014).

123 The ultimate goal of studying a glacial sediment routing system is to relate changing

124 boundary conditions including climate, tectonics, ice extent and ice surface topography to the ice

125 response, which in turn generates a mass flux signal. Documenting the relative roles of glacial

126 dynamics and the thermal state of the ice on sediment production and strata formation is the first

127 step (Fig. 1). Developing quantitative models for glacial and glacimarine settings follows, and is

128 paramount for advancing our ability to a) predict how changes in sediment production and

129 transfer are routed through a glacial system, in order to b) interpret the resulting stratigraphic

130 record. 
132 Is the modern the key to interpreting the past?

133 How applicable are modern process-based studies for deciphering the Pleistocene

134 landscape? Much of the Quaternary was a significantly colder and more ice-dominant period, yet

135 all of the observations have been made in a distinctively warmer climatic period following the

136 end of the Little Ice Age (LIA; Oerlemans, 2005) and within a relatively warm Pleistocene

137 interglacial period. Decades of field studies have attempted to interpret the modern sedimentary

138 glacigenic record to reconstruct the ice dynamics that create sediment (e.g., Anderson et al.,

139 1980; Powell, 1983; Mackiewicz et al., 1984; Griffith and Anderson, 1989; Powell and Molnia,

140 1989; Cowan and Powell, 1990; Domack and Williams, 1990; Phillips et al., 1991; Domack and

141 Ishman, 1993; Hunter et al., 1996a; Cowan et al., 1998; Ashley and Smith, 2000; Jaeger, 2002;

142 Hambrey and Glasser, 2012). Does this modern perspective result in a bias in our understanding

143 of the relative magnitude of glacial processes in the past? For example, erosion rates that have

144 been inferred from contemporary sediment yields of temperate tidewater glaciers far surpass

145 those of polar and alpine glaciers (Gurnell et al., 1996; Hallet et al., 1996; Koppes et al., 2015).

146 Moreover, modern (annual to centennial) erosion rates far outpace erosion rates averaged over

147 the long term $\left(10^{3}-10^{6}\right.$ years) from these same glaciers (Fig. 3; Berger and Spotila, 2008; Delmas

148 et al., 2009; Koppes and Montgomery, 2009; Fernandez et al., 2011). The two- to three-order of

149 magnitude difference in apparent erosional efficiency of these glaciers over annual to million-

150 year timescales brings into question what aspects of modern settings or analogues of processes

151 may be biased by the current "warm" glaciological conditions.

152 Building on the pioneering $19^{\text {th }}$ century work by Agassiz, Lyell and others, the field of

153 glacial geology has witnessed a wide-ranging effort, from ice sheet summits to deep sea basins, 
154 to document and explain how ice shapes the land-ocean-atmosphere interface. Recent

155 recognition that our currently warming climate is accelerating terrestrial ice loss (Rignot et al.,

156 2014), with notable societal impacts (Marzeion et al., 2014), has only heightened our need to

157 understand how ice has responded in the past to climatic perturbations. Here we review the

158 current state of knowledge on the generation, transfer, and accumulation of glacigenic sediment

159 from terrestrial sources to continental-margin sinks (see Fig. 1 for our conceptual approach). We

160 draw on the state of knowledge from various disciplines, including geomorphology, marine

161 geology, geochronology, numerical modeling of surface processes and landscape evolution,

162 experimental and field observations of glacier erosion and deposition, the interaction of ice with

163 its bed, and of meltwater with the ocean, to highlight the processes and controls on glacigenic

164 sedimentary signals from source to sink. Given the long history of glacial studies, comprehensive

165 reviews already exist on the fundamentals of glacial and glacimarine processes and strata

166 formation under the full range of climatic conditions (Molnia, 1983; Anderson, 1999; Stokes and

167 Clark, 2001; Bennett, 2003; Benn et al., 2007; Winsborrow et al., 2010; Cook and Swift, 2012;

168 Hambrey and Glasser, 2012; Livingstone et al., 2012; Landvik et al., 2014). Rather, our primary

169 goal here is to examine glacial systems from a synoptic source-to-sink viewpoint, with a focus on

170 describing: a) how glacial motion produces sediment; b) how the sedimentary record (sink)

171 records the dynamic nature of glacial systems under different climatic (thermal) regimes; c) the

172 challenges in using the sedimentary record to interpret these dynamics in space and time; and d)

173 the approaches still needed to further our understanding of how ice and sediment fluxes may

174 respond to future climatic and other perturbations. Figure 2 serves as our conceptual model of the

175 key spatial and temporal components of a holistic source-to-sink understanding of glacial

176 systems. 


\section{$178 \quad 2 . \quad$ Signals from the Source: The role of glaciers in sediment production}

A rigorous understanding of the processes that create the glacigenic sedimentary signal is

181 necessary to infer climatic and glaciological changes from complex stratigraphic records.

182 Climate dictates the ice flux and thus the geomorphic work done by the ice generating the

183 sedimentary mass flux signal. Changes in sedimentary mass flux correspond with seasonal-,

184 annual-, centennial- and millennial-scale ice dynamics that reflect different climate forcings (Fig.

185 2, column A). Ice extents define the boundary conditions and the magnitude of the spatial

186 response, but do not necessarily elucidate the ice dynamics, i.e., the flux response of the ice to

187 climate drivers. The primary means by which we can interpret the sink in terms of its ability to

188 resolve these ice dynamics is based on observations in modern settings, where the relationship

189 between current ice dynamic states (mass balance, mass transfer, and thermal regime) and the

190 bedforms, strata and mass fluxes generated can be established. The interpretive approach can

191 either be inverse (i.e., using the sedimentary record to infer ice dynamics) or forward (i.e.,

192 employing coupled ice-sediment-landscape evolution models) (e.g., Braun et al., 1999;

193 Dowdeswell and Siegert, 1999; Tomkin and Braun, 2002; MacGregor et al., 2009; Herman et al.,

194 2011; Egholm et al., 2012; Yanites and Ehlers, 2012). In this section we review the fundamental

195 controls on glacial erosion and sediment production, starting with the controls on ice dynamics

196 and how they reflect climate, and then address how changes in ice dynamics influence the

197 amount and timing of sediment production and transfer to the terrestrial-marine boundary.

199 2.1. Ice Dynamics: Characteristic timescales of response and controls on thermal regime 
202 and energy with the atmosphere, the hydrosphere and the lithosphere (Benn and Evans, 2010).

203 The growth of a glacier or ice sheet is dictated by its mass balance, the net accumulation of snow

204 (and its conversion to ice) minus the mass loss by melting and calving, which in turn depend on

205 climate and local topographic factors. At the most basic level, alpine glaciers and terrestrial ice

206 sheets thicken and advance when the overall mass balance (accumulation minus mass loss) is

207 positive, and thin and retreat when the mass balance is negative. Similarly, glacier temperature is

208 a function of the inputs/outputs of energy at the surface and the bed, and controls the rate of ice

209 motion through deformation and sliding (Cuffey and Paterson, 2010). Fluctuations in glacier

210 mass balance and temperatures are therefore strongly coupled responses to climate change. A

211 glacier's climate sensitivity is the magnitude and timing of changes in mass balance in response

212 to a given perturbation in temperature and/or precipitation. The mass balance dictates both the

213 extent of the ice (its growth and decay), the flux of ice and meltwater through the glacial system

214 (i.e., the transfer of mass from accumulation to ablation zones) and the average ice thickness.

215 The ice flux and the ice thickness in turn control the conditions at the glacier bed, primarily the

216 basal water pressure and rate of basal ice motion, which dictate the capacity of the ice to do

217 geomorphic work on the bed (i.e., to erode) (see Fig. 4; Hallet, 1979, 1996; Iverson, 1991, 2012).

218 For a rapidly moving glacier, much of the ice motion is due to basal sliding, which is needed for

219 the ice to erode; in contrast, for a glacier that is slow-moving (i.e., partially frozen to its bed),

220 much of the motion is due to internal deformation of the ice (Fig. 4a). Hence, climatic

221 differences between regions, as well as within a glaciated basin over time, dictate variations in

222 mass balance, basal temperature, availability of meltwater and ice flow in space and time, which 
223 in turn influences the sediment yield and the sedimentary signal (e.g., Hallet et al., 1996;

224 Dowdeswell et al., 1998; Koppes and Montgomery, 2009; Koppes et al., 2015).

225 To first order, global climate forced by orbital control on insolation has long been

226 recognized as the primary driver for Quaternary glacier and ice sheet mass balance on millennial

227 time scales (Fig. 2 column A); however, interactions with climate are complex and non-linear.

228 For instance, the high albedo of snow and ice acts as a positive feedback on ice sheet mass

229 balance (e.g., Box et al., 2012; Dumont et al., 2014). The presence of a continental-scale ice

230 sheet impacts global and local patterns of air circulation, creating stable high-pressure zones with

231 steep pressure gradients that discourage inflow of moist air and enhance buoyancy-driven

232 katabatic winds (e.g., Steffen and Box, 2001; Parish and Bromwich, 2007). Moreover, ice sheets

233 can modify precipitation patterns due to orographic factors, resulting in enhanced accumulation

234 rates nearest the coasts (Roe, 2005).

235 At the subannual timescale, seasonal melting is the most important driver of ice

236 dynamics, particularly for temperate systems where meltwater can more readily reach the ice-bed

237 interface without refreezing, and help both lubricate the interface to increase ice flux and do

238 geomorphic work on the bed (Alley et al., 1997). Hence, seasonal melt dominates the seasonal-

239 annual sedimentary flux signal (Fig. 2 A, B). Water input is known to vary on a daily basis

240 during the summer season, which has an important effect on sliding velocities (e.g., Iken and

241 Bindschalder, 1986; Bartholomaus et al., 2007). Seasonal meltwater fluctuations have strong

242 control on subglacial channel dimensions (Boulton et al., 2007) and sliding velocities (e.g., Iken

243 and Bindschalder, 1986; Bartholomaus et al., 2007; Joughin et al., 2008; Pimentel et al., 2010;

244 Schoof, 2010). In the winter, subglacial water conduits close because of lower water pressures,

245 and any unfrozen water is trapped in a network of linked cavities. Increased melt rates in summer 
246 drive higher subglacial water discharge and the formation of larger, more efficient channels, and

247 the subglacial drainage system evolves accordingly. Therefore, it is likely that every year, there

248 is a period when drainage networks shift from sluggish to efficient flow to drain subglacial

249 meltwater. During this shift, subglacial water pressure is large and effective pressure is low,

250 which promotes sliding and erosion, and the linked production of a sediment pulse (Fig. 2 B).

251 On decadal to centennial timescales, such as the Little Ice Age (LIA), several studies

252 have demonstrated a primary relationship between glacier mass balance and inter-annual

253 variability in large-scale atmospheric circulation patterns, variation in solar cycles, and changes

254 in oceanic temperatures and circulation. For instance, a decade of positive mass balance can

255 force temperate glacier surges (Eisen et al., 2001). In the Andes, higher sea-surface temperatures

256 associated with El-Niño events have been linked with persistent negative mass balance of the

257 Peruvian ice caps (Thompson et al., 1984). In western North America, the Pacific Decadal

258 Oscillation drives contrasting patterns of winter snowfall, creating negative mass balances for

259 Pacific Northwest glaciers, but positive mass balance for Alaskan glaciers (Bitz and Battisti,

260 1999). Across south-central Greenland, a strengthening and warming of the sub-polar Irminger

261 current have been linked to increases in submarine melting and the acceleration of the ocean-

262 terminating outlet glaciers of the Greenland Ice Sheet (e.g. Rignot et al., 2010; Motyka et al.,

263 2011; Straneo and Heimbach, 2013).

264 Glaciers respond to climatic perturbations that affect their net mass balance by adjusting

265 their width, length, and thickness (Dowdeswell et al., 1995; Eisen et al., 2001; Harrison and Post,

266 2003; Davis et al., 2009; Menounos et al., 2009; Roe and Baker, 2014). There is a lag in the

267 adjustment of the ice that depends on the response time of the glacier, which is dictated by its

268 geometry (Roe and Baker, 2014). Modern observations of alpine glaciers show response times 
269 from several years to decades (Harrison et al., 2001; Oerlemans, 2005; Menounos et al., 2009).

270 Temperate glaciers are known to surge within a few decades following changes in mass balance,

271 releasing large volumes of sediment and meltwater (Fig. 2 A, B) (Eisen et al., 2001; Striberger et

272 al., 2011). Alpine glacial termini advanced within a few centuries associated with LIA cooling,

273 and their subsequent retreat occurred within $~ 50-100$ years (Oerlemans, 2005; Barclay et al.,

274 2009). The end of the LIA in Alaska is reflected in increased proglacial sediment accumulation

275 and glacigenic sediment discharge (Fig. 2 B; Molnia and Post, 1995; Wiles et al., 1999; Barclay

276 et al., 2009; Crossen and Lowell, 2010; Jaeger and Kramer, 2014). Proxy records of ice retreat

277 associated with the abrupt warming transition at the Bølling interstadial at $14.8 \mathrm{ka}$ BP indicate a

278 response time within the precision of the chronometer (several hundred years; Praetorius and

279 Mix, 2014).

280 However, the timing and magnitude of retreat can be unrelated or minimally related to

281 climate forcing, which is particularly true of glaciers in marine-terminating settings. Many

282 modern outlet glaciers terminate in fjords or lakes, and their response to climate is complicated

283 by their sensitivity to non-climatic influences such as terminus geometry, sediment delivery to

284 the terminus, ice-front melt rates, and water depth (Meier and Post, 1987; Powell, 1991; van der

285 Veen, 1996; Warren and Aniya, 1999; Motyka et al., 2003; O'Neel et al., 2005; Pfeffer, 2007;

286 Rignot et al., 2010). Consequently, advance-retreat histories of calving glaciers contain a record 287 both of past climate and of changing ice-front dynamics. 
According to theory and experimental evidence, the two fundamental mechanical

293 processes that govern the erosion and shaping of landscapes by ice are: a) quarrying of rock

294 blocks from rough edges of the subglacial bed; and b) abrasion of rock that smoothens and

295 polishes the bed (Fig. 4; Boulton, 1979; Hallet, 1979, 1996; Iverson, 1991, 2012). In certain

296 climates and lithologies, abrasion and chemical denudation by meltwater also may play a

297 significant role in erosion; however, less is known about these mechanisms (Anderson and

298 Anderson, 2010). These theories all suggest that subglacial water pressure, and corresponding

299 basal sliding velocity, are the dominant mechanisms that control the tempo of subglacial erosion.

300 Warmer annual temperatures and higher precipitation rates (both rain and snow) favor meltwater

301 production, which is likely to increase the basal water pressure, leading to faster sliding and

302 more erosion (Fig. 2; Iken and Bindschadler, 1986; Bartholomew et al., 2010). High basal water

303 pressures also are thought to promote subglacial erosion by quarrying, especially where they

304 fluctuate frequently (Fig. 4; Hallet, 1996; Iverson, 2012). Indeed, for Alaskan temperate glaciers,

305 observational data have correlated increases in sliding velocities (inferred from measured

306 increases in glacier surface speeds) with increases in the production and transport of glacial

307 sediment (Fig. 5; e.g., Humphrey and Raymond, 1994; Anderson et al. 2004; Riihimaki et al., 308 2005).

309 In polar glaciers and ice sheets where cold-based ice (below the pressure melting point)

310 dominates, glacial erosion and sediment transfer rates decrease significantly (Hallet et al., 1996;

311 Elverhoi et al., 1998; Cuffey et al., 1999; Koppes et al., 2012). As mean air temperatures drop

312 well below $0^{\circ} \mathrm{C}$, the production of sediment by glacial erosion decreases progressively as surface

313 melt vanishes, because little or no water reaches the bed from the glacier surface to facilitate

314 glacier sliding and erosion. Sediment production is greatly limited once the basal ice temperature 
315 drops below the melting point, and erosion rates are then dominated by slow mechanical

316 processes associated with ice deformation (Hallet et al., 1996; Cuffey et al., 1999). The role of

317 glacial meltwater in transporting sediment subglacially also diminishes as the air cools because

318 subfreezing conditions shut off the dominant source of water; the amount generated through

319 frictional heating at or near the glacier bed has little impact on sediment transport (e.g. Cuffey

320 and Paterson, 2010). Under these circumstances, sediment transport under the glacier is

321 presumed to take place primarily in a deforming basal till layer and in basal ice, and not by

322 subglacial or englacial streams (Fig. 4; Griffith and Anderson, 1989; Hooke and Elverhoi, 1996;

323 Powell et al., 1996; Bennet, 2003). However, recent sediment yield data from an outlet glacier in

324 Greenland suggest that efficient subglacial drainage of surface meltwater in the wet snow zone

325 close to the edges of the Greenland Ice Sheet may create a zone of rapid erosion along the

326 margins of cold-based (polar) ice sheets (Cowton et al., 2012).

327 Several aspects of the processes and mechanics of glacier erosion remain unconstrained.

328 In contrast to fluvial studies, where the importance of bedrock lithology in fluvial incision rates

329 has been demonstrated (e.g., Stock and Montgomery, 1999), the explicit influence of rock type

330 on glacial erosion is still little understood (Alley et al., 2003). Both chemical weathering rates

331 (Anderson et al., 2005) and fracture intensity may also influence glacial erosion rates (Dühnforth

332 et al., 2010; Becker et al., 2014). The degree to which the presence of subglacial meltwater and

333 sediment at the bed affects both short-term and long-term glacial erosion is also still debated. For

334 example, glacial hydrology is expected to influence sediment transfer by accelerating sliding,

335 and hence erosion, in the ablation zone where abundant meltwater is available (e.g., Herman et

336 al., 2011; Egholm et al., 2012). Theoretical models for subglacial abrasion highlight the

337 influence of sediments carried by the ice as a driving factor for subglacial erosion (Hallet, 1979, 
1996; Iverson, 1991, 2012). Yet, sediments may also act to reduce erosion if allowed to

339 accumulate at the bed and provide a protective cover for the bedrock surface (e.g., Egholm et al.,

340 2012). Moreover, subglacial storage of sediments will also delay the timing between the

341 production of sediment through erosion and its sedimentary signal at the ice front and beyond.

\section{2.2.2. Observations of glacial erosion and sediment production}

344 Quantifying the controls and timing of glacier erosion is central to understanding the role

345 of climate forcing on the development of sedimentary signals in a glacial sediment routing

346 system, yet relationships between these controls are still poorly understood. In part this is due to

347 the difficulty of making direct observations and measurements of glacial erosion beneath or

348 directly in front of active glaciers. There is also a paucity of techniques to measure rates of

349 erosion over both short and long timescales in glacially modified landscapes. Sediment

350 accumulation patterns, rates and volumes near glacier termini in fjords of the northern and

351 southern hemispheres have been examined using sequential bathymetric maps, seismic-reflection

352 surveys, sediment traps and radioisotope analyses (e.g., Molnia, 1983; Cowan and Powell, 1990,

353 1991; Domack and Ishman, 1993; Hallet et al., 1996; DaSilva et al., 1997; Elverhøi et al., 1998;

354 Jaeger and Nittrouer, 1999a,b; Koppes and Hallet, 2002, 2006; Koppes et al., 2009, 2010;

355 Szczucinski et al., 2009; Fernandez et al., 2011). Based on these measures of short-term

356 sediment yields, the rapidity with which glaciers erode the bed can be high, in some instances for

357 temperate glaciers, far outpacing the erosion rate of rivers (Fig. 6; Gurnell et al., 1996; Hallet et

358 al., 1996; Koppes and Montgomery, 2009). However, the relationship between the magnitude

359 and timing of sediment yields measured today and of the geomorphic and dynamic processes that

360 produce the erosional signal have received remarkably little attention, and with a few notable 
361 exceptions (e.g., Riihimaki et al., 2005; Koppes and Hallet, 2006; Cowan et al. 2010), are still

362 poorly understood. The importance of ice dynamics on sediment production was first

363 quantitatively demonstrated by studies of Variegated Glacier, Alaska, in the early 1980s, where a

364 two-order-of-magnitude variation in sediment yield was measured over a two-year surge cycle

365 (Fig. 5; Humphrey and Raymond, 1994). During this surge event, sliding speeds also increased

366 by two orders of magnitude, but the extent of glacier cover did not change appreciably. Notably,

367 the subglacial discharge increased dramatically at the end of the surge, suggesting that subglacial

368 meltwater flushing may contribute a significant amount of sediment to the proglacial system

369 during distinct (seasonal to interannual) events (Fig. 2 B; Merrand and Hallet, 1996). These

370 findings showed that the dynamic nature of a glacier dictates the rate at which it can erode,

371 entrain subglacial sediments and deliver them to the ice front, creating a cryospheric sedimentary

372 signal of changing glacier mass balances.

373 Given the logistical complexities inherent in establishing subglacial erosion rates

374 quantitatively, a critical component is to determine a chronology for sediment deposition in the

375 glacial foreland and glacimarine realms. Tools developed to understand these depositional

376 processes, and to address the multiple factors that affect sedimentary records created by

377 fluctuating glacial sediment input, include: a) direct measurements of suspended sediment

378 concentrations in fjords and lakes to monitor sediment release and transport mechanisms (e.g.,

379 Domack and Williams, 1990; Cowan and Powell, 1991); b) radioisotope analysis and varve

380 counting of seabed samples from shallow cores (e.g., Cowan et al., 1997; Jaeger and Nittrouer,

381 1999a,b; Cowan et al., 1998; Jaeger, 2002; Ohkouchi and Eglinton, 2008; Rosenheim et al.,

382 2008; Boldt et al., 2013); c) optical and thermoluminesence dating of sediments (Fuchs and

383 Owen, 2008; Berger et al., 2010; Alexanderson and Murray, 2012); d) paleomagnetism (Stoner 
384 et al., 2000; Brachfeld et al., 2003; Simon et al., 2012); and e) seismic stratigraphy and facies

385 analyses recorded in strata (e.g., Cai et al., 1997; Elverhoi et al., 1998; Jaeger et al., 1998; Sheaf

386 et al., 2003; Koppes and Hallet, 2006; Koppes et al., 2009; Cowan et al., 2010; Fernandez et al.,

387 2011). Given the spatial and temporal variability in sediment and meltwater discharge at glacial

388 termini (e.g., Powell and Molnia, 1989; Domack and Ishman, 1993), spot measures in space

389 and/or time of sediment accumulation (a-d) are potentially inadequate to capture the dominant

390 time scale of sediment production, and thus data sets that capture the full flux over space and

391 time (e) are advantageous. However, seismic volumes can only be converted to rates when

392 chronologies and physical properties (e.g., p-wave velocity, bulk density) exist to complement

393 the seismic stratigraphy. Often, only gross assumptions of ages of seismic surfaces can be made,

394 for instance glacial retreat surfaces following LGM or LIA (Elverhoi et al., 1998; Jaeger et al.,

395 1998; Sheaf et al., 2003; Koppes et al., 2010), which limits our abilities to examine the dynamics

396 of sediment fluxes over time.

397 Much of what is known about contemporary and centennial sediment yields from glaciers

398 comes from coastal Alaska and Patagonia, where numerous studies have quantified the

399 sediments in the fjords and on the shelf (e.g., Molnia, 1979; Cowan and Powell, 1990, 1991;

400 Powell, 1991; Hallet et al., 1996; DaSilva et al., 1997; Jaeger et al., 1998, 1999b; Koppes and

401 Hallet, 2002, 2006; Sheaf et al., 2003; Boyd et al., 2008; Koppes et al., 2009, 2010; Cowan et al.,

402 2010). From the measured sediment volumes in fjords and historical records of terminus retreat,

403 Koppes and Hallet $(2002,2006,2009)$ modeled the sediment yields of tidewater glaciers in

404 Alaska and Patagonia on an annual basis, based on seismic reflection isopachs, and suggested

405 that the temperate tidewater glaciers in both regions have been unusually dynamic and erosive in

406 the past century since the end of the LIA, when regional warming caused rapid terminus retreat 
407 and the drawdown of hundreds of meters of ice. They inferred that the acceleration in ice flow

408 required to evacuate such immense volumes of ice from the basins since the LIA resulted in

409 accelerated basal sliding, and the unusually fast sliding (relative to the typical conditions of the

410 late Pleistocene) produced modern erosion rates (Fig. 2 C) that are among the highest known

411 yields worldwide and far exceed those over the long-term (Figs. 3, 6).

412 The study by Cowan et al. (2010) stands out for their contribution in terms of

413 documenting sedimentary processes and rates of debris transfer from the glacial source to a fjord.

414 They documented the retreat of Muir Glacier, Alaska and the associated migration of the active

415 depocenter through silled fjord basins at nearly annual resolution for over a century. They

416 concluded that the sediment yield derived from seismic isopachs reflects several sources, and

417 that sediment fluxes measured during retreat should not be considered to represent only bedrock

418 erosion supplied by varying ice flux from Muir Glacier, but also includes contributions from

419 tributary glaciers as well as pre-LIA sediment stored within the deeper basins that is re-eroded by

420 advancing ice. Moreover, sediments are often redistributed from bedrock highs into deep basins.

421 Hence, temporal variations in sediment input from tidewater glaciers represent variations both in

422 production of new debris by erosion as well as in inputs from sediment stored under and in front

423 of the glacier.

424 Over longer time scales (10-400 ka), averaging several glacial cycles, recent advances in

425 cosmogenic exposure dating have greatly enhanced our ability to define glacial erosion and

426 deposition rates in the terrestrial environment. The use of cosmogenic nuclides has provided a

427 means of directly dating the deposition of subaerial glacial deposits in the absence of any

428 associated organic remains, a common issue for Quaternary deposits (Balco, 2011; Granger et

429 al., 2013). Cosmogenic exposure-age dating, which relies on the measurement of rare nuclides 
430 produced in rock surfaces and sediments by cosmic ray bombardment, is now widely used to

431 date both late Pleistocene and Holocene deglaciation ages as well as to quantify subglacial

432 erosion rates via the nuclide concentration in glacially transported boulders and in bedrock

433 exposed during retreat (Balco, 2011). Advances in the use of cosmogenic nuclide isotopes

434 (Miller et al., 2002; Briner et al., 2006; Briner and Kaufman, 2008; Menounos et al., 2009;

435 Balco, 2011; Fastook and Hughes, 2013; Granger et al., 2013; Champagnac et al., 2014; Cofaigh

436 et al., 2014; Hormes et al., 2013; Refsnider et al., 2013; Hodgson et al., 2014; Larter et al., 2014;

437 Lindow et al., 2014; Rother et al., 2014; Winsor et al., 2014) have helped resolve a number of

438 longstanding chronological and process debates in geomorphology, including: topographic relief

439 development (e.g., Tremblay et al., 2014) and the ability of cold-based ice sheets to preserve pre-

440 glacial landscape features (e.g. Stroeven et al., 2002; Briner et al., 2006); complex Holocene

441 glacial exposure-burial histories (e.g. Goehring et al., 2011); and accumulation rates of glacial

442 sediments deposited 0.5 to $3 \mathrm{Ma}$ (e.g., Balco and Rovey, 2010). However, the accuracy of

443 cosmogenic exposure dating remains limited by uncertainties about production-rate calibrations

444 and assumptions about the geologic history of landforms that are difficult to test and may

445 profoundly effect their apparent ages, complicating the glacial and erosional history of landforms

446 and strata (Balco, 2011; Heyman et al., 2011).

447 Developments in low temperature thermochronometry also have allowed quantification

448 of glacial erosion rates at the million-year timescale appropriate for investigating tectonic-

449 climatic forcing on topographic development. Four low-temperature thermochronometric

450 systems are used: apatite (U-Th)/He, apatite fission track, zircon (U-Th)/He and zircon fission

451 track, which have approximate closure temperatures of $\sim 60-90{ }^{\circ} \mathrm{C}, 110{ }^{\circ} \mathrm{C}, 180{ }^{\circ} \mathrm{C}$ and $250{ }^{\circ} \mathrm{C}$,

452 respectively. Taken together, these thermochronometers enable the tracking of bedrock erosion 
453 from shallow crustal depths of about 8-10 km up to the Earth's surface (e.g., Herman et al.,

454 2013). These temperatures and bedrock cooling histories correspond to the glacial-interglacial

455 phase of topographic denudation (e.g, Shuster et al, 2005). For instance, recent low temperature

456 thermochronometric studies along the glaciated coasts of Alaska, British Columbia and in the

457 Patagonian Andes support the notion of rapid glacial erosion at altitudes near the snowline (Fig.

458 3) (Shuster et al., 2005; Berger and Spotila, 2008; Thomson et al., 2010; Herman et al., 2013).

459 One notable drawback to this method is that bedrock cooling ages can only be established where

460 samples can be collected, which precludes sampling under modern ice streams that may be the

461 locus of erosion over LGM time scales (Berger et al., 2008b; Enkelmann et al., 2010; Headley et

462 al., 2013). One alternative is to use detrital thermochronometery on grains collected from glacial

463 outwash. Where this has been accomplished from modern glaciers, the results are ambiguous in

464 terms of the exhumation rates under the glaciers, which may reflect decadal-scale variability in

465 subglacial sediment storage and transfer that influences the cooling age spectra of grains sampled

466 from outwash (Headley et al., 2013).

468 2.2.3. Modeling erosion and sediment production under conditions of glaciation

469 Increasingly, the effects of glacial erosion on geomorphic development of topography

470 and the production of a sedimentary signal is being studied using landscape evolution models,

471 which provide numerical simulations of both ice flux and glacier erosion over periods spanning

472 multiple glaciations. The geomorphic signatures of glacial landscapes, such as U-shaped valley

473 cross-sections, low-sloping longitudinal profiles punctuated by steep steps, overdeepened

474 bedrock basins and fjords, cirques, and hanging valleys, clearly demonstrate differences in the

475 erosional capacity of fluvial and glacial systems (e.g. Harbor et al., 1988; Braun et al., 1999; 
476 Kessler et al., 2008; MacGregor et al., 2009; Pedersen and Egholm, 2013). However, there has

477 been slow progress directed toward quantitatively understanding the development of these

478 geomorphic features, quantifying the timescale of their formation, or determining the rates of

479 glacigenic sediment production. Most recent numerical modeling efforts have focused on

480 reproducing the processes that produce the hypsometric signature of a glaciated landscape,

481 including erosion by glacial sliding and isostatic landscape uplift caused by erosional unloading

482 (e.g., MacGregor et al., 2009; Yanites and Ehlers, 2012; Pedersen and Egholm, 2013).

483 Central to these glaciated landscape evolution models is the need for a simple index that

484 relates the glacial erosion rate, i.e., sediment production rate, to glaciological or climatic

485 variables. Most models assume that erosion rates are proportional to the ice sliding velocity at

486 the bed, and reach a peak at the equilibrium line altitude (ELA) (e.g., Harbor, 1992; Braun et al.,

487 1999; Tomkin and Braun, 2002; Egholm et al., 2009; MacGregor et al., 2009; Tomkin, 2009;

488 Herman et al., 2011). Some models assume that glacial erosion can be approximated by the 489 integrated ice discharge (Anderson et al. 2006, Kessler et al., 2008; Headley et al., 2012).

490 Although treatments of glacier flow in these models have become increasingly sophisticated

491 (e.g., Herman et al., 2011; Egholm et al., 2012), the constraints placed on the erosion rate have 492 remain unchanged, and most apply a bedrock erosion $(E)$ rule of the form:

$$
E=K_{g} u_{s}^{n}
$$

496 where $u_{s}$ is the glacier sliding speed, $K_{g}$ is a constant representing bedrock erosion susceptibility, 497 and $\mathrm{n}$ is a constant normally assumed to be 1 (e.g., Harbor, 1992; Tomkin 2007, 2009; Herman 498 and Braun, 2008; Egholm et al., 2009; MacGregor et al., 2009; Herman et al., 2011; Yanites and 
499 Ehlers, 2012). In nearly all of these cases, the two constants of proportionality used have been

500 tuned to a single empirical study in which both the sediment flux and ice motion were measured

501 during a surge of Variegated Glacier in Alaska (Fig. 5; Humphrey and Raymond, 1994).

502 While field studies and some of the most recent modeling studies have shown that water

503 plays a major role in modulating sliding (Herman et al., 2011; Egholm et al., 2012), with

504 important implications for enhanced erosion, the impact it may have on sediment yields and

505 erosion rates is still unclear. Beaud et al. (2014) found that variations in seasonal subglacial

506 drainage pattern, sliding speeds, and the form of the erosion rule used resulted in significant

507 differences in predicted erosion rates. Thus, improved empirical data on the patterns and

508 development of subglacial hydrology, and on the role of hydrology in modulating erosion and

509 sediment production, are still needed.

510 Documenting the timing of subglacial sediment generation at the source and transfer to

511 the sink also is complicated by paraglacial changes in erosional and transport pathways

512 throughout glacial advance-retreat cycles. For example, De Winter et al. (2012) modeled the

513 change in erosion and sediment generation to the glacial foreland during deglaciation, and found

514 a distinct time lag between glacier warming and retreat, and a corresponding increase in erosion

515 and sediment production. They attributed this lag to rising concentrations of abrasive agents (i.e.

516 sediment) in the basal ice and an increase in sliding. They also noted that the lag between

517 warming (and deglaciation) at the glacier source and the increase in sediment delivery to the

518 proglacial sinks may be complicated by sediment storage in the terrestrial and fluvial transfer

519 domains, creating a pulse of paraglacial reworked sediments in the proglacial foreland following

520 deglaciation (Church and Ryder, 1972; Church and Slaymaker, 1989; Ballantyne, 2002). 


\section{$522 \quad 3 . \quad$ Linking the source to the sink: glacigenic signal transfer}

523

524

525 which glacigenic sediment is transferred from the locus of production (i.e., the glacial source) to

526 the locus of accumulation (i.e., the glacimarine sink), and how these dispersal pathways are

527 controlled by ice dynamics and related controls such as sea level. In contrast with river systems

528 that are persistent on the landscape over millions of years, a primary question for glacial S2S

529 systems is how the signal is transferred, especially when the glaciers are no longer present in the

530 landscape.

531 Sediment is transferred from where it is eroded within the source zone to the terminus

532 (the source/transfer zone boundary) (see Fig. 1) through several well-documented processes,

533 including superglacial and englacial rafting within the ice, transport in a deformable till or

534 debris-laden basal ice layer at the ice-bed interface, or carried in the subglacial hydrologic

535 system (Fig. 4; Alley et al., 1997). The dominant sediment transfer process will depend on the

536 thermal state of the ice. In temperate, meltwater-dominated systems, the primary mode of

537 sediment transfer is through subglacial meltwater conduits (Lawson, 1993; Alley et al., 1997).

538 Superglacial meltwater feeding the subglacial system can rapidly advect sediment through the

539 glacier, and subglacial flow can flush all available sediment stored beneath the ice (Alley et al.,

540 1997; Hunter et al., 1996a; Swift et al., 2005). In colder systems such as in Antarctica, basal

541 melting is greatly reduced, and meltwater discharge is minimal (Alley et al., 1997; Griffith and

542 Anderson, 1989; Koppes et al., 2015).

543 Subglacial sediment transport also can occur by deformation of till at the glacier bed, and

544 may be the dominant mode of transport under ice streams (Fig. 4b; Kristoffersen et al., 2000; 
545 Bennett, 2003). Characteristic basal sediment thicknesses of less than $0.5 \mathrm{~m}$ have been measured

546 beneath temperate Alaskan tidewater glaciers (e.g., Kamb et al., 1985; Humphrey et al., 1993).

547 The few observations of these deformable till layers from boreholes suggest they are no more

548 than a few meters thick at most (Engelhardt et al., 1990; Truffer et al., 1999). Transport also

549 occurs by freezing to the sole of the glacier, resulting in thick zones of debris-rich basal ice

550 where regelation and freeze-on from supercooled subglacial water is prevalent (Alley et al.,

551 1997; Creyts et al., 2013). Sediment fluxes associated with ice streams range from $10^{2}$ to $10^{3} \mathrm{~m}^{3}$

$552 \mathrm{yr}^{-1}$ per meter ice width (Alley et al., 1987; Alley, 1989; Hooke and Elverhoi, 1996; Tulaczyk et

553 al., 2001; Shipp et al., 2002; Dowdeswell et al., 2004; Anandakrishnan et al., 2007; Laberg et al.,

554 2009; Christoffersen et al., 2010). To generate and sustain such a large sediment flux, subglacial

555 sediment transfer near the ice margins must be dominated by thick zones of deforming till (Alley

556 et al., 1989; Anandakrishnan et al., 2007; Livingstone et al., 2012) or debris-rich basal ice layers

557 (Christoffersen et al., 2010).

$558 \quad$ Local geology and basin topography dictate how much mass wasting occurs, shedding

559 sediment onto the ice surface, and hence the relative amount of supraglacial and englacial debris

560 transported by the ice (e.g., Alley et al., 1997). The magnitude of the sediment transported

561 directly by ice is, however, considered a minor contributor to the overall flux. For instance,

562 Hunter et al. (1996a) found that, for three relatively "dirty" Alaskan tidewater glaciers where

563 bedrock erodibility was relatively high and where small but significant portions of the basins

564 were above the ice surface and available to contribute superglacial debris, the superglacial and

565 englacial debris entrained in the ice amounted to no more than $10 \%$ of the total sediment yield.

566 Changes in subglacial hydrology and subglacial storage also may influence transfer of

567 sediment along dispersal pathways within the glacier 'source' zone, adding complexity to the 
568 sedimentary record in the ice-proximal sink. Subglacial basins can act to temporarily store both

569 sediment and water (Cook and Swift, 2012). Any change in the sediment-transport capacity of

570 the subglacial hydrologic system, such as caused by a decrease in bed slope due to subglacial

571 sediment storage or an increase in surface slope as the glacier thins, can evacuate stored sediment

572 (Alley et al., 1987; Motyka et al., 2006; Cuffey and Patterson, 2010; Cook and Swift, 2012).

573 Hence, the sedimentary signal at the ice-ocean boundary is not a simple record of changes in the

574 sediment production rate due to changes in climate or erosion rate. Because changes in

575 subglacial hydrology and storage may dominate the sediment flux to certain ice-proximal

576 settings, a simple interpretation of sediment fluxes as a metric of ice flux is challenging, as

577 subglacial hydraulics are arguably the least understood component of the glacier system.

578 In contrast, a substantial set of investigations into the physical processes in fjords has

579 provided a conceptual framework for modeling the flux and fate of glacial sediment that enters

580 marine waters (e.g., Elverhoi, 1984; Powell, 1984; Syvitski et al., 1987; Cowan and Powell,

581 1990, 1991; Domack and Williams, 1990; Domack and Ishman, 1993; Domack et al., 1994;

582 Harris et al., 1999; Ashley and Smith, 2000; Gilbert et al., 2003). While some glacimarine

583 sedimentary dispersal processes such as turbid meltwater plumes have been measured in situ, or

584 inferred from fjord sedimentary deposits, the specific transport mechanisms, especially near the

585 terminus, can only be inferred from geophysical or acoustic sampling (e.g., Powell, 1990;

586 Domack et al., 1994; Goff et al., 2012). However, rare is the situation where termini are

587 subareally exposed following retreat to allow documentation of the full range of transport

588 processes (Smith et al., 1990; Phillips et al., 1991).

589 In glacimarine environments, most glacially derived sediment enters proglacial fjords via

590 subglacial meltwater discharge, and to a much lesser extent by direct melting of the calving front 
591 and of icebergs (Figs. 1, 7, 8; e.g., Powell and Molnia, 1989; Cowan and Powell, 1991; Hunter et

592 al., 1996b). The majority of sediment is thought to be delivered to temperate fjords via subglacial

593 and englacial meltwater channels (Hunter et al., 1996a); at the terminus, subglacial discharge

594 generally rises as a turbulent plume that mixes with ambient seawater (Fig. 8 inset; Powell and

595 Molnia, 1989; Syvitski, 1989). Some of the highest sediment accumulation rates measured

596 worldwide occur near the grounding line of temperate glaciers, and reach up to meters per year

597 (Powell, 1981, 1983, 1990, 1991; Goff et al., 2012). Empirical studies of proglacial

598 sedimentation rates in front of temperate-polythermal tidewater glaciers all suggest that they

599 decrease exponentially with distance from the ice front, reflecting rapid sediment deposition

600 (hours-days) of suspended sediment (Syvitski, 1989, Cowan and Powell, 1991, Dowdeswell et

601 al., 1998; Hill et al., 1998; Jaeger and Nittrouer 1999b). Such rapid sedimentation processes have

602 been quantitatively (Powell, 1990) and numerically (Mugford and Dowdeswell, 2011; Salcedo-

603 Castro et al., 2013) modeled and are highly dependent upon the time-evolving jet dynamics at

604 the subglacial conduit and suspended-sediment flocculation dynamics in the water column (Hill,

605 1998).

606 The dominant sediment-transport process in meltwater-dominated fjord depends strongly

607 on the subglacial meltwater sediment concentration. For sediment-laden freshwater to exceed the

608 density of the ambient fjord seawater, the suspended-sediment concentration needs to exceed $\sim 30$

$609 \mathrm{~g} \mathrm{l}^{-1}$ (Mulder and Syvitski, 1995). At concentrations $<30 \mathrm{~g}^{-1}$, subglacial meltwater plumes

610 become buoyant and travel along the water surface, as sediment flocculates and settles to the

611 seabed (e.g., Cowan et al., 1988; Hill et al., 1998; Curran et al., 2004). If the plume is

612 hyperpycnal $\left(>30 \mathrm{~g}^{-1}\right)$, high-concentration gravity flows can carry sediment along the fjord

613 seabed great distances from the source (e.g., Prior et al., 1987; Syvitski et al., 1987; Willems et 
614 al., 2011). Gravity flows, including hyperpycnal flows, disperse highly mobile sediment along a

615 flat seabed; gravity-flow strata are a significant component of the sedimentary facies

616 accumulating proximal to the ice (Fig. 7; Syvitski, 1989; Willems et al., 2011; Hambrey and

617 Glasser, 2012). Secondary meltwater input from tributary glacifluvial sources can add to mass

618 fluxes and also result in gravity flows and turbidite deposition (Fig. 8; Dowdeswell and Vásquez,

619 2013). Sinuous turbidity-current channels are common to temperate fjords influenced by highly

620 variable discharge from glacifluvial braided rivers (Prior et al., 1986; Syvitski et al., 1987;

621 Dowdeswell and Vásquez, 2013).

622 Sediment delivery into polar fjords is controlled primarily by calving and ice rafting, with

623 most of the sediment accumulating directly at the ice front (Fig. 7a; Domack and Ishman, 1993;

624 Hambrey and Glasser, 2012). Broad variations in the amount of sediment produced and in the

625 role of meltwater facilitating glacial sediment transport are evident from several studies across

626 the Antarctic Peninsula. For example, biogenic sediments are dominant in polar fjords in

627 Antarctica indicating relatively minimal terrigenous input (Domack and Williams, 1990),

628 whereas the subpolar bays of the Antarctic Peninsula receive greater fluxes of terrigenous

629 sediment (Griffith and Anderson, 1989; Domack and Ishman, 1993; Anderson, 1999; Boldt et al.,

630 2013), thought to be delivered by suspended-sediment plumes and influenced by currents

631 (Domack and Williams, 1990; Domack et al., 1994; Yoon et al., 1998; Harris et al., 1999; Ashley

632 and Smith, 2000). Bottom and intermediate plumes, which appear to originate at the grounding

633 line, transport the majority of suspended sediment in polar and subpolar settings (Fig. 7a) (e.g.,

634 Domack et al., 1994). Observed temporal variability of these plumes suggests time-varying

635 subglacial discharge as the dominant control. However, the mechanisms generating these

636 plumes, for instance tidal action or meltwater discharge, remain poorly understood (Domack and 
637 Williams, 1990; Domack et al., 1994; Domack and Harris, 1998). Sediment transfer by turbidity

638 currents, debris flows, rain-out debris, and meltwater-derived sediments also have been

639 interpreted as occurring in sub-iceshelf environments in the vicinity of the grounding line of

640 polar ice sheets (Fig. 7; Anderson, 1999; Domack et al., 1999; Licht et al., 1999; Evans and

641 Pudsey, 2002; Hillenbrand et al., 2005).

642 Iceberg rafting of sediment can also be a volumetrically significant transfer mechanism,

643 especially in polythermal and polar settings (Fig 7). Ice-rafted debris (IRD) accumulation is

644 commonly assumed to indicate that the marine terminating ice flux was high, supplying enough

645 mass to allow for wide dispersal of coarse-grained sediment (Ruddiman, 1977; Molnia, 1983;

646 Powell and Molnia, 1989; Krissek, 1995; Cowan et al., 1997; Anderson, 1999; St. John and

647 Krissek, 1999; Clark and Pisias, 2000; Hemming, 2004; Tripati et al., 2008; Forwick and Vorren,

648 2009; Marcott et al., 2011; Cofaigh, 2012; Patterson et al., 2014). The amount of IRD

649 transferred along the dispersal system also depends on the amount of material entrained in the

650 ice, the amount of time it takes icebergs to transit the transfer zone, and the melting rate along

651 this transit (Andrews, 2000). Time-varying fluxes of IRD to a specific site have been used as

652 evidence of the dynamic extent of the ice (Hebbeln et al., 1998; Solheim et al., 1998; Stokes et

653 al., 2005; Patterson et al., 2014), but the interpretation of IRD concentrations as simply a proxy

654 for ice margin stability has been questioned (St. John and Krissek, 1999; Andrews, 2000; Clark

655 and Pisias, 2000). In the iceberg-dominated margins of East Greenland (Dowdeswell et al.,

656 1998), higher concentrations of IRD are assumed to represent major periods of calving

657 associated with a retreat of the ice front (Elverhoi et al., 1998a; Funder et al., 1998). In

658 Antarctica, IRD concentrations in open marine sediments do not appear to be related to ice sheet

659 dynamics, but rather reflect relative winnowing of fines by strong bottom currents (Cofaigh et 
660 al., 2001b; Hemming 2004; Cofaigh, 2012) and other deepwater sediment reworking processes

661 over the past million years. In temperate glacial settings, higher concentrations of IRD have been

662 associated with ice margin retreat on continental shelves (Hendy and Cosma, 2008), but may also

663 reflect seasonally varying suspended-sediment concentrations in fjords (Cowan et al., 1997).

664 Thus, post-depositional reworking also can bias IRD accumulation rates. Regional oceanography

665 can also have a major impact on IRD dispersal patterns, varying greatly over short distances

666 (Solheim et al., 1998). For example, two ODP cores taken $75 \mathrm{~km}$ apart on the East Greenland

667 shelf showed a significant seaward decrease in IRD content, likely influenced by the East

668 Greenland Current, which has kept icebergs closer to the margin and prevented eastward

669 transport to the outer shelf (Larsen et al., 1994).

670 Continental shelves impacted by glacial processes share a common set of characteristics

671 that reveal the dynamics of ice and sediment transfer over a larger range of time scales (Figs. 1,

672 2D). Ice streams flowing from ice masses of all sizes are the predominant transfer mechanism of

673 ice, meltwater, and sediment to and across continental shelves (Figs. 9 and 10; Bentley, 1987;

674 Cofaigh et al., 2003; Cofaigh et al., 2008; Stokes and Tarasov, 2010; Livingstone et al., 2012;

675 Batchelor and Dowdeswell, 2014; Dowdeswell et al., 2014; Landvik et al., 2014). Deep (100-

$6762000 \mathrm{~m}$ ) cross-shelf troughs are the geomorphic signature of paleo-ice streams, interpreted to

677 represent the main ice routes across the continental shelf, often to the shelf break (Fig. 10). These

678 troughs link up with major sediment depocenters and dispersal systems on continental slopes

679 (Bentley, 1987; Cofaigh et al., 2003; Dowdeswell et al., 2008a; Reece et al., 2011; Livingstone et

680 al., 2012; Batchelor and Dowdeswell, 2014; Dowdeswell et al., 2014; Landvik et al., 2014;

681 Larter et al., 2014; Walton et al., 2014). Between ice streams, slower flowing ice transfers less

682 mass but is primarily recognizable from a depositional record of nested arcuate moraines 
683 marking the positions of former ice margins (Fig. 10; Dowdeswell et al., 2002; Landvik et al., 684 2005; Ottesen et al., 2007, 2009; Ottesen and Dowdeswell, 2009; Cofaigh et al., 2012; Landvik 685 et al., 2014).

686 Continental slopes and the adjacent deep basins are the ultimate sink for glacigenic 687 sediment that has been supplied to the glacimarine transfer zone, reworked, and advected to the 688 more distal part of the system (Figs. 1 and 2 E, F). Sediment cores and seismic facies in the deep 689 sea reveal that gravity flows and hemipelagic settling are the main transfer mechanisms to these 690 sinks (Figs. 1, 11; Dowdeswell et al., 1996; Dowdeswell et al., 1998; Wilken and Mienert, 2006; 691 Reece et al., 2011; Cofaigh, 2012; Garcia et al., 2012; Batchelor and Dowdeswell, 2014; Walton 692 et al., 2014). Debris flows are ubiquitous on continental slopes seaward of cross-shelf troughs 693 that were occupied by ice streams (Figs. 10, 11; Laberg and Vorren, 1996; King et al., 1998; 694 Taylor et al., 2002a; Batchelor and Dowdeswell, 2014; Dowdeswell et al., 2014; Rebesco et al., 695 2014). Deposition of debrites results in the formation of trough mouth fans, the primary 696 depositional landform on many northern hemisphere margins (Vorren et al., 1998; Dahlgren et 697 al., 2002; Elverhoi et al., 2002; Taylor et al., 2002a; Cofaigh, et al., 2003; Dahlgren et al., 2005; 698 Nielsen et al., 2005; Batchelor and Dowdeswell, 2014; Rebesco et al., 2014). Trough mouth fans 699 occur wherever slopes are < 4 degrees (Cofaigh, et al., 2003; Batchelor and Dowdeswell, 2014); 700 on steeper slopes, gravity flows supply sediment to deep submarine basins via large submarine 701 channels (Dobson et al., 1998; Reece et al., 2011; Garcia et al., 2012; Walton et al., 2014).

702 Although gravity flows transfer large volumes of glacigenic sediment onto slopes and into 703 deepwater basins (Reece et al., 2011; Garcia et al., 2012; Walton et al., 2014), suspended 704 sediment settling from turbid surface and intermediate water depth plumes dominates the 705 temporal record in these settings (Taylor et al., 2002c). At shelf margins in Antarctica and NE 
706 Greenland, trough mouth fans are rare to absent (Livingstone et al., 2012; Batchelor and

707 Dowdeswell, 2014), and the prevalent gully morphology suggests that density flows drive near-

708 bed sediment transport to deeper basins (Nielsen et al., 2005; Dowdeswell et al., 2008b;

709 Noormets et al., 2009; Livingstone et al., 2012; Gales et al., 2013). The lack of trough mouth

710 fans in these settings may either reflect steeper continental shelf breaks or lower sedimentation

711 rates than are required to construct a low-angle slope (Livingstone et al., 2012; Gales et al.,

712 2013). This observation suggests that reduced sediment fluxes from polar ice sheets influence

713 continental slope morphology at the highest latitudes.

714

\section{4. The Sink - Fidelity of the Glacigenic Signal}

716

The major objective of studying a sediment routing system from source to sink is to

718 establish the fidelity of the stratigraphic record in capturing the dynamics of the geomorphic

719 processes creating sediment, the drivers of those processes, and the internal routing dynamics.

720 Relating dynamic ice fluxes (i.e., velocity) to strata formation in glacial S2S systems requires

721 quantification of glacigenic sediment accumulation rates, which depends on resolving the

722 sedimentary record at timescales equal to or better than the characteristic timescale of the ice

723 response in question (Fig. 2; Cofaigh et al., 2002). This is most easily accomplished in modern

724 temperate, meltwater-dominated glacial systems, because sediment production is elevated and

725 thus signal generation is the strongest, resulting in higher mass fluxes that produce the

726 accumulation rates necessary to resolve the recent or short-timescale ice response function

727 (Cowan et al., 1997; Dowdeswell et al., 1998; Dowdeswell and Siegert, 1999; Jaeger and

728 Nittrouer, 1999a; Jaeger, 2002; Andresen et al., 2012; Pedersen et al., 2013). For modern 
729 iceberg-dominated systems, reduced production and flux of sediment to the sink limits our ability

730 to quantify the relationship between ice flux (velocity) and the stratigraphic signal for short (sub-

731 annual to decadal) timescales (Harden et al., 1992; Domack and McClennen, 1996; Lowe and

732 Anderson, 2002; Hillenbrand et al., 2010a; Kirshner et al., 2012; Boldt, et al., 2013).

733 Consequently, the greatest advances in linking ice dynamics at modern to Quaternary advance-

734 retreat time scales to sedimentary signal preservation exist for meltwater-dominated systems

735 (Fig. 2).

$736 \quad$ Establishing links between lithostratigraphy and glacial geomorphology requires

737 identifying the genesis of the sedimentary signal, which is most easily accomplished in currently

738 glaciated settings. Interpreting the ice influence on strata formation depends on recognizing

739 distinctive lithofacies and/or seismic-facies assemblages characteristic of glacial settings (e.g.,

740 Svendsen et al., 1992; Faleide et al., 1996; Dowdeswell et al., 1998; Licht et al., 1999; Anderson

741 et al., 2002; Powell and Cooper, 2002; McKay et al., 2009; Cowan et al., 2010; Dowdeswell and

742 Fugelli, 2012; Hambrey and Glasser, 2012; Hogan et al., 2012; Kirshner et al., 2012; Batchelor

743 et al., 2014; Dowdeswell et al., 2014; Larter et al., 2014; Rebesco et al., 2014). Many diagnostic

744 lithofacies criteria for recognizing glacigenic processes depend on examination of clast fabric,

745 grain orientation, physical properties, and biofacies (Powell, 1983; Powell and Molnia, 1989;

746 Eyles and Eyles, 1992; Dowdeswell et al., 1998; Wellner et al., 2001; Cofaigh et al., 2007;

747 Garcia et al., 2011; Cowan et al., 2012, 2014; Hambrey and Glasser, 2012; Kirshner et al., 2012;

748 Larter et al., 2014). Lithofacies information from point sources (e.g., cores) reveals local

749 temporal changes, whereas marine geophysics are often used to capture the spatial variability in

750 glacigenic strata formation. Even then, individual, acoustically-stratified seismic facies

751 interpreted as glacigenic, such as suspended sediment deposition, are not unique to ice- 
752 dominated settings. The most powerful combination for establishing the extent of glacigenic

753 influence in the sink is to relate seismic facies to lithofacies within a chronostratigraphic context

754 (Anderson et al., 2002; Barrie and Conway, 2002; Dahlgren et al., 2002; Cofaigh et al., 2004;

755 Nygård et al., 2007; Laberg et al., 2009; Hogan et al., 2010a).

756 Sedimentation associated with a moving terminus within the transfer zone leaves behind

757 a record of ice extent, which is a secondary signal of ice dynamics, but it cannot be used to

758 quantify the relationship between ice sliding velocity and sediment produced (Figs. 1, 5).

759 Documenting this sedimentation is the most common approach used to relate the stratigraphic

760 record with ice dynamics (extent) for glacial S2S systems. In this way, the glacial sedimentary

761 record is treated as a binary (on/off) signal reflected in the deposition of characteristic glacigenic

762 lithologic, geochemical, and/or seismic facies (e.g., Rebesco et al., 2006; Anderson et al., 2014;

763 Cofaigh et al., 2014; Hogan et al., 2010; Larter et al., 2014; Patterson et al., 2014; Reyes et al.,

764 2014; Dowdeswell, et al., 2014; Simon et al., 2014). However, the drawback to this approach is

765 that the depositional record (e.g., diamict; laminated or massive mud; graded beds; chaotic or

766 transparent seismic reflectors) observed in modern glacial environments are not unique to a

767 particular thermal regime (Powell and Molnia, 1989; Dowdeswell et al., 1998; Licht et al., 1999;

768 Evans and Pudsey, 2002; Garcia et al., 2011; Cofaigh and Dowdeswell, 2001; Cofaigh et al.,

769 2001a). Proper discrimination of the climatic setting from a binary signal depends on holistically

770 describing facies assemblages/distributions (Cofaigh et al., 2013; Garcia et al., 2011; Cofaigh

771 and Dowdeswell, 2001; Cofaigh et al., 2001a). Even then, similar lithofacies assemblages (e.g.,

772 diamict to laminated mud to massive mud) can accumulate under widely varying climatic

773 regimes (Garcia et al., 2011; Cofaigh et al., 2001a). Only by establishing the geomorphic context

774 and sediment accumulation rates is it possible to differentiate between lithofacies associated with 
775 meltwater- versus iceberg-dominated systems, and thus capture the association between changes

776 in ice flux and sediment production (Smith and Andrews, 2000; Desloges et al., 2002).

777 Observations of the dynamic response of ice to external forcing at various timescales

778 allow us to generate hypothetical sediment mass flux response functions (Fig. 2). The challenge

779 in using field data to derive a response function is placing time constraints on the sedimentary

780 record. The most robust examples are those where accumulation rates can be coupled with

781 unambiguous facies or morphologic indicators of glacigenic sources. As noted, establishing

782 temporal control relies on a chronostratigraphy commensurate with the response time of the

783 perturbation (Kroon et al., 2000). Consequently, the number of studies that establish absolute

784 rates of glacimarine processes and accumulation rates is most numerous for short-term (seasonal-

785 centennial) processes. As the timescales of interest expand into the late Pleistocene, the available

786 chronometers have uncertainties greater than $10^{2}$ yrs (Austin et al., 1995; Davies-Walczak et al.,

787 2014; Hall, 2009), which is greater than the ice response time seen in the late Holocene (Nesje et

788 al., 2008; Oerlemans, 2005; Wiles et al., 2008). In instances where chronologies are lacking,

789 sedimentary, geomorphic, and geophysical proxies such as IRD, laminated mud and diamict

790 lithofacies, seabed morphology, grounding zone wedges (GZW), and/or mega-scale glacial

791 lineations (MSGL) have been used to infer an ice-dynamic relationship to the stratigraphic

792 signature. Rates of landform formation derived from modern analogues are provided wherever

793 possible (Anderson, 1999; Andrews and Principato, 2002; Anderson et al., 2014; Andreassen and

794 Winsborrow, 2009; Batchelor and Dowdeswell, 2014; Batchelor et al., 2013; Cai et al., 1997;

795 Cofaigh et al., 2008; Cofaigh et al., 2005; Cowan et al., 1997, 2010; DaSilva et al., 1997;

796 Domack, 1990; Dowdeswell et al., 2000; Hambrey and Glasser, 2012; Hogan et al., 2010; Jaeger

797 and Nittrouer, 1999b; Larter et al., 2014; Livingstone et al., 2012; Mackiewicz et al., 1984; 
798 Molnia, 1983; Ottesen et al., 2005; Ottesen et al., 2008a,b; Phillips et al., 1991; Powell and

799 Cooper, 2002; Powell and Molnia, 1989; Shipp et al., 2002; Wellner et al., 2006; Willems et al., 800 2011).

801 Examples of using glacigenic stratigraphy to resolve ice flux dynamics range from fjords 802 to the deep sea, and from sub-annual to the Pleistocene timescales (Figs. 1, 2). Given the

803 complexity and breadth of these records, we chose to focus this review on continental-margin

804 settings, as they contain the volumetric bulk of the glacigenic sedimentary record (Fig. 2B-F).

805 For processes operating at the decadal to century timescale (e.g., surges; Fig. 2A), we provide

806 examples primarily from modern fjords where glaciers currently terminate, but recognize that a

807 sedimentary record of similar processes may also exist on shelves, slopes, and in the deep sea

808 whenever ice advanced through the transfer zone (e.g., LGM, Fig. 1). We also only focus on the

809 record where sediment is supplied directly by ice, as this provides the clearest illustration of the

810 ability of these records to resolve ice dynamics. We explicitly ignore glaciofluvial discharge

811 from former ice sheets that dominated North America, Europe, and Asia during the late

812 Pleistocene, as well as the transfer of this sediment from the glacial foreland to the ocean,

813 because determining terrestrial residence times and fluxes are hampered by limited chronologies

814 in terrestrial settings, as well as by the influence of eustasy in modulating fluxes from terrestrial

815 storage basins into the marine realm (e.g., Blum et al., 2000).

816

8174.1 Conditions that influence the magnitude of the mass flux signal

818

819 Observations from glaciated basins identify the relative processes that transfer the

820 sedimentary signal of ice flux or ice extent (Section 3), but they also illustrate processes that can 
821 introduce complexity in the interpretation of the sedimentary record. Establishing a glacigenic

822 sediment flux requires chronometric control that is most often established in sediment cores, but

823 spatial variability in dispersal processes will influence the flux to that point location. For

824 meltwater-dominated systems, spatial and temporal changes in delivery from the terminus affect

825 point measures in sediment accumulation rates. In temperate settings, sediment fluxes to

826 individual locations (e.g., core sites) will be highly dependent on the residence time of the

827 terminus near that location, because the absolute sediment flux to the seabed often decreases

828 exponentially from the ice-front source (Cowan and Powell, 1991; Powell and Domack, 1995;

829 Syvitski and Shaw, 1995; Gilbert et al., 1998). Where there is rapid deposition at the terminus,

830 the frequency and magnitude of downslope gravity flows will affect accumulation rates (Cofaigh

831 et al., 2013; Taylor et al., 2002a). Without additional spatial data (e.g., seismic reflection

832 profiles), it is challenging to place point measures of accumulation rates into the broader context

833 of dispersal processes to address potential biases (e.g., Willems et al., 2011).

834 For iceberg-dominated sinks, the sediment flux to any one location is dependent upon the

835 path and residence time of floating ice through the dispersal system. Where icebergs become

836 trapped by sea ice, the overall sediment flux to individual locations might be low because a large

837 component of subglacial and englacial sediment had previously melted out at the terminus

838 (Syvitski et al., 1996; Smith and Andrews, 2000; Mugford and Dowdeswell, 2010). When sea-

839 ice breaks up, there is an increase in iceberg flux through the system and a corresponding

840 increase in the sediment flux. For example, iceberg drift in Baffin Bay is strongly modulated by

841 seasonal sea ice limits, and by longer-term variations in the extent and duration of sea ice cover

842 (Deser et al., 2002; Andrews et al., 2014). For iceberg-dominated sinks covered by floating ice

843 shelves (e.g., the Ross Sea), the sediment flux will be low at sites distal to the grounding line. 
844 However, absolute sediment accumulation rates may increase as the ice sheet breaks up and

845 retreats and this leaves open water allowing for increased biogenic fluxes (Licht et al., 1996;

846 Milliken et al., 2009; Maddison et al., 2005, 2006; Leventer et al., 2006).

847 The size of the depocenter also can influence localized sediment accumulation rates. For

848 meltwater systems with high englacial/subglacial sediment fluxes, sediment dispersal in

849 meltwater plumes or turbidity currents will transfer material to deeper basins, thereby

850 distributing the mass over a larger area (Reece et al., 2011; Taylor et al., 2002b; Walton et al.,

851 2014). As sediment dispersal becomes increasingly distal from the source, sedimentation rates

852 decrease, allowing for secondary processes such as bioturbation to influence the stratigraphic

853 record, creating non-glacial "noise" in the system (Cofaigh et al., 2002; Romans et al., this

854 volume).

855 The sediment flux to a particular location also depends on the bedrock type and

856 morphology over which the ice flux does its geomorphic work. For many shelf systems, there is

857 a transition from crystalline rock on the inner shelf to sedimentary (often glacimarine) on the

858 outer shelf (Batchelor and Dowdeswell, 2014; Batchelor et al., 2011; Cofaigh et al., 2004;

859 Livingstone et al., 2012; Nielsen et al., 2005; Wellner et al., 2001; Ottesen et al., 2005). Over

860 comparable periods of erosion and sediment transfer to the sink, the flux signal will be larger for

861 a glacier that occupies more easily erodible bedrock (Hogan et al., 2012; Swift et al., 2008). For

862 example, higher erosion rates at Disko Bay, Greenland are in part related to the high erodibility

863 of the basaltic bedrock (Desloges et al., 2002). Troughs between bedrock highs can also focus

864 sediment accumulation (Hogan et al., 2012; Lowe and Anderson, 2002; Graham et al., 2010;

865 Jakobsson et al., 2012; Kirshner et al., 2012; Larter et al., 2014) producing a point measure of 
866 sediment accumulation that may reflect time spent in constrained bathymetry rather than the

867 volume of subglacially eroded material.

868 Lastly, autogenic factors can influence glacigenic sediment accumulation rates that are

869 independent of any external climatic forcing on ice flow and erosion. These influences can

870 complicate the ability to use the sedimentary record to inversely determine ice dynamics. The

871 duration of the terminus at any point on the shelf depends on the stability of the grounding line

872 (Powell 1991; Alley et al., 2007). In Antarctica, it is observed that retreat began earlier for ice

873 streams in deeper troughs than those in shallower troughs, suggesting that water depth influences

874 retreat dynamics (Livingstone et al., 2012), although Larter et al., (2014) suggest that local

875 bathymetric "bottle-necks" also influence ice stream retreat rates. A positive feedback may exist

876 where sediment accumulation is high enough to create a grounding-zone wedge that further

877 stabilizes the grounding line allowing for additional focused deposition. This may allow the

878 grounding line to remain in the same location even as sea level is changing (Powell 1991;

879 Warren et al 1995; van der Veen 1996; Fischer and Powell 1998). Also, the accumulation rate

880 used to determine sediment fluxes depends on the available accommodation. Net sediment

881 accumulation may be low even under high sediment input from the glacier terminus if

882 accommodation is low. This may exist where accommodation is reduced due to rapid sediment

883 accumulation (Powell and Molnia 1989; Powell 1990; Plink-Bjorklund and Ronnert 1999),

884 glacioisostatic loading creates a pro-glacial forebulge (Barrie and Conway, 2002), active tectonic

885 uplift (Powell and Cooper, 2002), or the low shelf gradients typical of divergent (passive)

886 margins (Cofaigh et al., 2003). Conversely, sediment accumulation rates in fjords or on the

887 continental shelf and slope may be low if accommodation is high and marine dispersal is 
888 efficient. This may be the case wherein higher slopes favor gravity flows that redistribute

889 sediment to deeper basins (Powell, 1991; Dobson et al., 1998; Cofaigh et al., 2003)

890

8914.3 Examples of signal fidelity at various timescales in the glacigenic sink

893 4.3.1 Sub-annual to annual time scales

894 Seasonal air temperature fluctuations result in changes in meltwater production and in ice

895 flux (Fig. 2A, B). In temperate systems, increased meltwater production in the summer lubricates

896 the bed, and is associated with increased sliding velocity (Bartholomew et al., 2010; Cuffey and

897 Paterson, 2010). The sliding speed for tidewater glaciers also is dependent on the presence of sea

898 ice that buttresses the terminus in the winter months and breaks up in spring, facilitating faster

899 flow (Mugford and Dowdeswell, 2010). In polar settings where meltwater generation is

900 restricted, the sediment supply comes from direct melting of the calving face and is driven by

901 ocean temperatures for marine-terminating ice (Domack and Ishman, 1993). Consequently, a

902 sub-annual to annual sedimentary signal is more prevalent in temperate settings with higher

903 meltwater fluxes (Fig. 2B).

904 For the vast majority of modern high-latitude continental margins, marine-terminating ice

905 is present only in fjords or on the inner shelf in Antarctica (Batchelor and Dowdeswell, 2014;

906 Livingstone et al., 2012). Modern glacigenic sediment delivery and measurements of

907 accumulation are generally limited to these settings (Figs. 1, 7, 8; Powell and Molnia, 1989;

908 Powell and Domack, 2002; Anderson, 1999). Sediment-trap measurements in temperate and

909 subpolar fjords support a temporally varying sediment flux throughout the year (Fig. 2C; Cowan

910 and Powell, 1991; Ashley and Smith, 2000; Svendsen et al., 2002; Phillips et al., 1991) driven by 
911 seasonal variability in meltwater production (Kempf et al., 2013; Svendsen et al., 2002; Griffith

912 and Anderson, 1989; Domack and Ishman, 1993; Yoon et al., 1998; Ashley and Smith, 2000).

913 Sedimentation rates can be as high as $10 \mathrm{~cm} \mathrm{~d}^{-1}$ and $10 \mathrm{~m} \mathrm{yr}^{-1}$ near the terminus of temperate

914 tidewater glaciers (Molnia, 1983; Cowan and Powell, 1991). Similarly, reduced sediment

915 deposition rates in the winter have been documented using short-lived radioisotopes (Jaeger,

916 2002; Muñoz et al., 2014). Interstratified mud in temperate fjords has been interpreted as annual

917 varves, with the interstratification of sand, coarse silt and mud created by fluctuations in

918 meltwater discharge and interactions with tidal currents to produce monthly and bimonthly

919 cycles (Cowan et al. 1998; Jaeger, 2002). Massive and stratified diamicts accumulate in the

920 winter, when IRD is not diluted by meltwater-driven sediment input, and the residence time of

921 icebergs in the fjords increases (Syvitski, 1989; Mackiewicz et al., 1984; Cowan et al., 1997,

922 1999; Dowdeswell and Cromack, 1991).

923 Accordingly, the sedimentary proxy of seasonal changes in meltwater and sediment input

924 in a meltwater-dominated, ice-proximal setting is an IRD-diamict interstratified mud couplet

925 (varve). The preservation of interannual stratification depends on sedimentation rates, which are

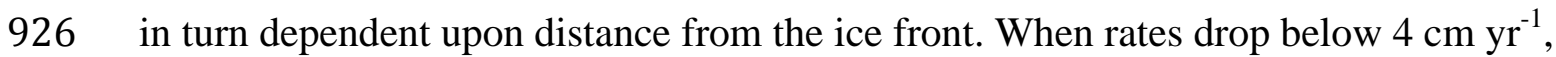

927 bioturbation homogenizes the record (Jaeger and Nittrouer, 1999b). In contrast to

928 glaciolacustrine sinks, where an empirical relationship has been shown to exist between

929 meltwater input and varve thickness (e.g., Chutko and Lamoureux, 2008), this approach has yet

930 to be conclusively demonstrated for temperate fjords (Pederson et al. 2013), which may reflect

931 the greater number of variables influencing sediment transfer from ice front to sink (Gilbert et al,

932 2002; Cofaigh and Dowdeswell, 2001). 
934 relatively high biogenic fluxes and low glacigenic sediment fluxes $\left(\sim\right.$ few $\left.\mathrm{mm} \mathrm{yr}^{-1}\right)$ often results

935 in a homogenous fjord lithofacies (sandy mud with dispersed clasts) greatly impacted by

936 bioturbation (Leventer et al. 1993, 2006; DeMaster et al., 1991; Powell and Domack, 2002;

937 Hillenbrand et al., 2010b; Maddison et al., 2005, 2006, McClintic et al., 2008). For example, at

938 Jakobshavn Isbræ in eastern Greenland, seasonal variation in calving rates due to changes in ice

939 velocity results in winter advance and summer retreat of the terminus (Joughin et al., 2012), yet

940 no annual signal from this process is recorded in the sediments, likely due to low sedimentation

941 rates relative to bioturbation rates (Cofaigh and Dowdeswell, 2001). Laminated facies can be

942 preserved, but they may reflect both increases in seasonal productivity, as well as sediment

943 resuspension during calving events and tidal influences (Ashley and Smith, 2000; Domack,

944 1990; Powell and Domack, 2002).

945 Given that most modern marine-terminating ice is restricted to fjords, there are few

946 examples of annual glacigenic strata formation on continental shelves or slopes (Jaeger and

947 Nittrouer, 1999b; Figs. 1, 2D, E). Although there may be seasonal increases in glacigenic

948 sediment discharge to some shelves (e.g., Merrand and Hallet, 1996; Jaeger and Nittrouer,

949 1999b), the sedimentation rate is generally not high enough to overcome homogenizing effects

950 from bioturbation to allow for preservation of a distinct annual signal (Fig. 2D; Cofaigh et al.,

951 2002; Jaeger and Nittrouer, 2006; Cofaigh and Dowdeswell, 2001).

952

953 4.3.2 Advance-retreat/surge time scales

954 The ice dynamics of the past 10-1000 yrs are characterized in many settings by episodic

955 advance-retreat events that can span from a year, i.e., a surge (e.g., Raymond, 1987) to hundreds 
956 of years, such as the Little Ice Age (Oerlemans, 2005; Dowdeswell et al., 1991). These events

957 are often observed in temperate and polythermal glacial settings, including Alaska, Svalbard, and

958 Chile (Kempf et al., 2013; Hagen et al., 1993; Dowdeswell et al., 2000; Dowdeswell et al.,

959 1991). Each event can be a consequence of a change in mass balance (Svendsen and Mangerud,

960 2007; Ottesen and Dowdeswell, 2006; Plassen et al., 2004; Kempf et al., 2013; Oerlemans, 2005;

961 Huybers and Roe, 2009; Jiskoot et al., 2000; Kamb et al., 1985; Molnia and Post, 2010; Murray

962 et al., 2003; Muskett et al., 2008; Ottesen et al., 2008a; Pritchard et al., 2005; Raymond, 1987),

963 or be independent of climate forcing (Murray et al., 2003; Nick et al., 2007). The ice flux is

964 expected to increase during the advance phase (Fig. 2A; Lingle and Fatland, 2003; Moon et al.,

965 2012; Murray et al., 2003), and also during the retreat phase (O'Neel et al., 2005; Koppes et al.,

966 2009), which could hypothetically generate two sediment pulses per event (Fig. 2 B,C). As with

967 annual signals, the magnitude of this glacigenic sediment signal is expected to be highest in

968 temperate, meltwater-dominated settings (Fig. 6) (Merrand and Hallet, 1996; Hallet et al., 1996;

969 Jaeger and Nittrouer, 1999b).

970 The ability to constrain the onset and termination of each surge event presents one

971 challenge for documenting the duration of an advance/retreat event using sediment accumulation

972 rates. For the timescale of the LIA, historical maps of termini positions, where available, can

973 constrain the event duration (e.g., Fig 12) (Ottesen et al., 2008b; Koppes et al., 2010; Cowan et

974 al., 2010). However, in most locations, resolving the duration of LIA and Neoglacial events in

975 the sedimentary record is challenging because of the imprecision of radiocarbon and other

976 geochronometers over these centennial response timescales (Austin et al., 1995; Hall, 2009;

977 Dowdeswell et al., 2000). 
The sedimentary signal produced by surges and advance-retreat events is mostly

979 observed in fjords where modern glaciers reside (Fig. 2C). For example, Gilbert et al. (2002)

980 captured the sediment flux associated with a short, five-year surge event in Disko Fjord, West

981 Greenland. The higher meltwater input during the surge resulted in the deposition of diurnal

982 laminated mud that accumulated up to 30 times faster than the long-term, pre-surge ${ }^{14} \mathrm{C}$-derived

983 accumulation rates. Additionally, Kempf et al. (2013) examined the changing lithofacies and

984 sediment fluxes associated with episodic "surge" events lasting for 200 years in Spitsbergen,

985 and found clast-rich, sporadically stratified glacimarine mud close to the morainal bank, which

986 decreased in accumulation rate by an order of magnitude following each event. The cores did not

987 have the temporal resolution to test for a hypothetical increase in sediment flux at the onset of

988 each event (Fig. 2C). Szczucinski et al. (2009) also documented a substantial increase in

989 sediment flux following the LIA in Billefjorden, Svalbard, and inferred that post-LIA increases

990 in temperature and negative glacier mass balance resulted in larger meltwater discharges both

991 eroding subglacial sediment stores and transferring considerable amounts of sediment from the

992 glaciers. Notably, the properties of the fjord sediments (grain size, IRD, coarse-fraction

993 composition, clay mineralogy) showed no distinct differences between those of the LIA advance

994 and the 20th century retreat.

995 Under certain conditions, centennial-scale advance/retreat events provide perhaps the best

996 opportunity to document how changing ice flux over an advance-retreat cycle impacts sediment

997 production. Establishing the chronology and duration of the event is critical to document the

998 changing sediment flux and can best be achieved when historical or terrestrial chronologies of

999 the event exist (e.g., Cowan et al., 2010; Koppes et al., 2010). Whereas point measurements

1000 (sediment cores) provide a measure of time-varying flux to local portions of the depocenter, the 
1001 inherent dynamics of sediment dispersal may result in a biased record of overall flux from the ice

1002 (Gilbert et al., 2002). To overcome this, the delineation of sediment/seismic volumes into

1003 discrete advance/retreat phases allows for capturing the total sediment produced through various

1004 dispersal processes. The ideal setting to test this is in a constrained basin where the total or

1005 majority of the sediment flux of the event can be captured (Fig. 12) (Koppes et al., 2010).

1006 Time-varying sediment fluxes associated with the retreat of the Muir Glacier, Glacier

1007 Bay Alaska, from its LIA maximum were established with seismic-reflection volumes

1008 constrained by historic termini positions (Cowan et al., 2010; Koppes and Hallet, 2002, 2006).

1009 Cowan et al. (2010) found that the sediment flux decreased in time with decreasing drainage

1010 basin area. Sediment input was established to be both from the retreating Muir Glacier but also

1011 from tributary sources and gravity flows shed from the sides of basins. Consequently, the

1012 temporal sediment-flux record associated with event-related ice dynamics must account for the

1013 time-varying extent of the ice volume. The ability to quantify fluxes over the full cycle of an

1014 event is challenging, because the advance phase removes some portion of the existing record

1015 within the basin (Cowan et al., 2010) and deposits it down-flow, often in wider distal basins

1016 where it accumulates with sediment from other sources. Because of this, most sediment-flux

1017 records of an event capture only the retreat phase. One exception to this was documented for

1018 Laguna San Rafael, Chile (Koppes et al., 2010). The use of historical navigational maps and

1019 aerial photos, coupled with bathymetric mapping and subbottom profiles allowed for the

1020 reconstruction of sediment volumes that were deposited during the advance, maximum LIA-

1021 standstill, and post-LIA retreat of the San Rafael Glacier (Fig. 12). The sediment fluxes were

1022 normalized to glacial basin area to derive an erosion rate, with the highest rates occurring at the 
1023 start of the retreat phase, and steadily decreasing as retreat continued. Erosion rates were more

1024 than 4 times lower during the glacial advance phase than during the retreat phase.

1025 In polar fjord settings, the sedimentary record of advance/retreat events is less clear. For

1026 example, Jennings and Weiner (1996) and Dowdeswell et al., (2000) documented the

1027 accumulation of stratified diamict and laminated mud during the LIA in Nansen Fjord, East

1028 Greenland and attributed the accumulation of this lithofacies to dynamic sea conditions that

1029 prevented IRD accumulation, providing another example of how changes in accumulation rates

1030 might reflect an autogenic response in the basin rather than a direct measure of glacigenic

1031 sediment flux. Conversely, Milliken et al. (2009) interpreted the $\sim 14$ ky-long multiproxy record

1032 from the SHALDRIL drill core retrieved from Maxwell Bay in the Antarctic Peninsula, and

1033 found several oscillations in ice extent in the proxy record but no distinctive intervals that reflect

1034 LIA or other late Holocene climatic fluctuations.

1035 On the continental shelf and in deeper water, the sedimentary record of decadal- to

1036 centennial-scale ice dynamics is poorly documented. Moreover, the deposition of non-glacigenic

1037 sediment at these time scales in high-latitude open water settings is expected to dominate the

1038 signal, and reflect basin-scale changes in water-column productivity or local bottom current

1039 strength (Fig. 2D-F; Cofaigh et al., 2002; Kroon et al., 2000; Radi and de Vernal, 2008; Taylor et

1040 al., 2002c). One notable exception is the LIA advance and retreat of the Bering Glacier in

1041 Alaska, which was recorded on the adjacent continental shelf and constrained onshore by

1042 dendrochronology (Wiles et al., 1999). Jaeger and Kramer (2014) found sediment accumulation

1043 rates doubled during the period of maximum ice extent, but due to uncertainty in marine

1044 reservoir ages/atmospheric production rates on ${ }^{14} \mathrm{C}$ ages, changes in sediment flux over the

1045 complete LIA cycle could not be established. 
1047 shelf are the isolated hummocks and ridges found in many fjords or inner continental shelves,

1048 which are interpreted as push moraines during advance or morainal banks formed by bedload

1049 dumping at the terminus during retreat (Figs. 1, 10; Dowdeswell and Vásquez, 2013; Landvik et

1050 al., 2014; Molnia, 1983; Ottesen and Dowdeswell, 2006; Ottesen et al., 2008a; Hald et al., 2001;

1051 Kristensen et al., 2009; Plassen et al., 2004; Kempf et al., 2013; Dowdeswell, 1995; Dowdeswell

1052 et al., 2014). For the last LIA event, recent terminus retreat and lower post-LIA sedimentation

1053 rates allow for these landforms to be observed and mappable in swath bathymetry (Ottesen et al;

1054 2008a). As noted by Boulton and Hagdorn (2006), such lobate landform features must be a

1055 consequence of local, fast ice streaming, where the response time of the ice dictates whether

1056 these features reflect a short-term surge event or a long-term occupation of the fjord by an ice

1057 stream. The challenge in using these features to quantify glacigenic sediment production during

1058 an event cycle is partitioning sediment that was previously deposited and has been remobilized

1059 and reworked into the morainal bank during the advance from newly-produced sediment that

1060 reflects the contemporaneous basal ice conditions and accounts for variable bedrock lithology

1061 (Fig. 12; Koppes et al., 2010).

1062

1063 4.3.3 Post-LGM deglacial timescales

1064 Over the period of the Last Glacial Maximum (LGM), large ice sheets dominated by ice

1065 streams were the major dispersal system generating and transferring sediments from land to

1066 ocean. However, the large variability in spatial extent of the ice during this period, which at

1067 times extended across the entire transfer zone (Fig. 1), presents a distinct challenge in preserving

1068 a sedimentary record in the sink. To depict glacigenic sediment production at LGM time scales 
1069 (Fig. 2B), we postulate changes in sediment fluxes based on observations of modern ice advance-

1070 retreat dynamics. For instance, from observations of one the few contemporary examples of a

1071 glacier advance at Taku Glacier in SE Alaska (Motyka et al., 2006) we can hypothesize that

1072 sediment flux to the terminus will be highest as the ice advances across the transfer zone

1073 (foreland, fjord, shelf, slope) under a cooling climate (Fig. 2A), because higher flux results from

1074 both the recycling of existing deposits in the transfer zone and increased bedrock erosion

1075 associated with the larger area of ice cover. Given observations of modern dynamics, we also can

1076 postulate that at the maximum stillstand associated with the coldest ocean and air temperatures,

1077 meltwater production, ice velocities and sediment transfer rates all would be lower (Fig. 2B).

1078 During deglaciation, sediment transfer to glacial termini would be expected to increase as a

1079 result of ice acceleration during retreat and drawdown (e.g., Koppes et al., 2010).

1080 The global withdrawal of ice sheets from their LGM maximum extents provides

1081 examples of the sedimentary flux associated with the late-Pleistocene to Holocene deglaciation

1082 phase (Henriksen 2014; Landvik et al., 1998; Ottesen et al., 2005; Evans et al., 2002; Kempf et

1083 al., 2013; Lekens et al., 2005). However, with the exception of examples from West Greenland,

1084 little is known about concurrent changes in the internal dynamics of the ice during this

1085 deglaciation. The hypothetical spatio-temporal sediment flux associated with this LGM-

1086 Holocene transition will reflect the duration and extent of the ice in each segment of the S2S

1087 system (Figs. 1, 2C-F). For instance, ice streaming and sediment erosion in fjords and in shelf

1088 troughs during the LGM will transition to net accumulation as the terminus retreats past a given

1089 point. Moreover, once deglaciation commences, glacigenic sediment accumulation on the

1090 continental slope and deep sea is rapidly reduced as the ice margin retreats landward (Fig. 2E-F). 
In a landmark paper, Elverhoi et al. (1998b) interpreted seismic reflection isopachs to

1092 establish glacigenic sediment production in Svalbard during the LGM-Holocene transition. They

1093 used changes in seismic facies associated with LGM retreat and dated episodic surge events in

1094 fjords to establish a chronology for the isopachs, and found that glacigenic sediment yields (i.e.,

1095 mass/drainage basin area/time) varied by more than an order of magnitude over the Holocene.

1096 The highest rates were associated with deglaciation, decreasing from the Early Holocene to a

1097 Mid Holocene low, corresponding to the regional climatic optimum. Sediment yields increased

1098 again during the Late Holocene reflecting ice readvance; they interpreted this increase in flux to

1099 reflect both increased subglacial erosion and redistribution of paraglacial sediment that had been

1100 stored in the proglacial basin during the middle Holocene.

1101 In contrast, in West Greenland, marine records of LGM-Holocene glacigenic sediment

1102 fluxes in the fjords and on the shelf are relatively few, but recent field data have added

1103 substantial information about ice dynamics in this region (Roksandic, 1979; Kuijpers et al., 2007;

1104 Hogan et al., 2011; Schumann et al., 2012; Dowdeswell, et al., 2014; Hogan et al., 2012; Cofaigh

1105 et al., 2013). During the LGM, ice streams from western Greenland extended to the shelf edge

1106 through Uummannaq and Disko troughs, and retreated episodically after 14.8 kya (Cofaigh et al.,

1107 2013; Dowdeswell, et al., 2014). Sediment accumulation rates from cores collected from the

1108 shelf troughs decreased by a factor of 5-10 from the start of deglaciation to the present (Cofaigh

1109 et al., 2013). Hogan et al. (2012) used seismic reflection isopachs to quantify sediment volumes

1110 and demonstrated that the highest sediment accumulation rates occurred during deglaciation,

1111 comparable to the highest modern rates from temperate environments (e.g., Hallet et al., 1996;

1112 Koppes and Montgomery, 2009). Whereas the fjords of West Greenland currently exhibit

1113 relatively low glacigenic sediment fluxes (Lloyd et al., 2005; Lloyd, 2006; Desloges et al., 2002; 
1114 Cofaigh et al., 2013), the high sediment accumulation rates during deglaciation suggest higher

1115 meltwater and sediment inputs, and thus higher ice fluxes, during this period (Hogan et al.,

1116 2012).

1117 Other examples of elevated sediment fluxes during deglaciation exist in high-latitude

1118 fjords. Laberg et al. (2009) determined that the glacigenic sediment accumulation rate during the

1119 LGM retreat of the Vestfjorden paleo-ice stream, part of the northwestern Fennoscandian Ice

1120 Sheet, was significantly elevated relative to overall Holocene rates, with calculated bedrock

1121 erosion rates of $>1 \mathrm{~mm} \mathrm{yr}^{-1}$, equivalent to rates from Svalbard and other Fennoscandian ice

1122 streams (Elverhøi et al. 1998b). The SHALDRIL drill core retrieved from Maxwell Bay in the

1123 Antarctic Peninsula recorded glacigenic sedimentation rates that decreased from $31 \mathrm{~mm} \mathrm{yr}^{-1}$

1124 during the LGM-Holocene transition to $4 \mathrm{~mm} \mathrm{yr}^{-1}$ in the late Holocene, reflecting significant

1125 warming and grounding line retreat at the end of the LGM (Milliken et al., 2009).

1126 On continental slopes that received sediment directly from the former LGM ice sheets in

1127 Svalbard, Alaska, and British Columbia, individual cores record the deglaciation transition as an

1128 order of magnitude decrease in sediment flux that reflects terminus retreat and substantial

1129 contraction of ice (Fig. 13; Barrie et al., 1991; Hendy and Cosma, 2008; Davies et al., 2011;

1130 Lekens et al., 2005; Vorren et al., 1998). Higher glacigenic sediment fluxes during the initial

1131 deglacial period are recognized both in terms of ${ }^{14} \mathrm{C}$ - or $\delta^{18} \mathrm{O}$-established chronologies and also

1132 from lithofacies proxies (e.g., laminated glacimarine mud). Importantly, these higher fluxes can

1133 be directly related to the dynamics of the ice through meltwater events interpreted from

1134 planktonic foraminiferal $\delta^{18} \mathrm{O}$ records associated with destabilization of the ice sheets (Evans et

1135 al., 2002; Hendy and Cosma, 2008; Davies et al., 2011; Lekens et al., 2005). 
1136 On continental margins, sediment accumulation rates of hemipelagic, IRD, and gravity

1137 flow deposits also reflect temporal changes associated with LGM ice extents (Fig. 13b). In East

1138 Greenland, ice advance across the shelves to the LGM maximum extent is revealed by increased

1139 mass accumulation rates on the continental slope (Funder et al., 1998; Evans et al. 2002).

1140 Subsequent decreased glacigenic sediment accumulation and IRD fluxes to the slope likely

1141 indicate ice retreat from the shelf (Funder et al., 1998), which is supported by increasing

1142 glacigenic sediment accumulation rates on the inner shelf (Fig. 13b). However, Funder et al.

1143 (1998) noted that the IRD flux signal on the East Greenland shelf must be carefully interpreted in

1144 terms of ice dynamics, as high IRD fluxes can occur under both colder conditions (ice advance to

1145 shelf edge) or warmer conditions (no sea ice present to trap icebergs).

1146 Along the Antarctic margin, the sedimentary record of ice dynamics has been

1147 predominantly used to determine the maximum extent at the LGM and the subsequent history of

1148 deglaciation, especially of the West Antarctic Ice Sheet (WAIS). This region is currently

1149 experiencing accelerated volume loss due to increased ice velocities of the many outlet glaciers

1150 and ice streams (Anderson et al., 2014; Hillenbrand et al., 2014; Larter et al., 2014; Rignot et al.,

1151 2014). In many respects, this region serves as a key example of how marine geophysics,

1152 sedimentology, and cosmogenic dating can be used to establish ice extent and dynamics, as is

1153 thoroughly discussed in several comprehensive review papers (Anderson et al., 2014; Cofaigh et

1154 al., 2014; Hillenbrand et al., 2014; Hodgson et al., 2014; Larter et al., 2014; Mackintosh et al.,

1155 2014). Ice extent and dynamics in the Antarctic marine realm are determined from dating

1156 subglacial to glacimarine to open-marine lithofacies transitions (see Anderson et al., 2014;

1157 Cofaigh et al., 2014; Hillenbrand et al., 2014; Hodgson et al., 2014; Larter et al., 2014;

1158 Mackintosh et al., 2014 for cited studies). Because of the scarcity of calcareous fossils in 
1159 Antarctic shelf sediments, it is particularly challenging to use marine ${ }^{14} \mathrm{C}$ to develop constraints

1160 on the timing of deglaciation and the accompanying sediment flux (Anderson et al., 2002;

1161 Andrews et al., 1999; Hall, 2009; Hillenbrand et al., 2010a; Larter et al., 2014; Licht and

1162 Andrews, 2002). In light of these dating challenges, the ability to recognize the large-scale

1163 regional controls on ice extent (e.g., shelf bathymetry, oceanographic forcing) is easiest when all

1164 chronological controls are synoptically summarized (Anderson et al., 2014; Cofaigh et al., 2014;

1165 Hillenbrand et al., 2014; Larter et al., 2014). Doing so reveals that the maximum extent of the

1166 WAIS at the LGM was variable across the shelf. Initial deglaciation was asynchronous, and

1167 deglaciation was variable in space, particularly on the inner shelf (Bentley et al., 2014). Although

1168 chronologies can be established for ice retreat along the Antarctic margin, the record is not well

1169 enough resolved to establish the variability of sediment fluxes associated with retreat (Leventer

1170 et al., 2006; Licht et al., 1996).

1171 In summary, the fast terminus retreat and rapid drawdown of ice associated with the

1172 retreat phase of modern tidewater glaciers suggests that ice fluxes and corresponding sediment

1173 fluxes should be elevated during deglaciation (Humphrey and Raymond, 1994). Examination of

1174 temperate and polar sedimentary records reveals high sediment accumulation rates at various

1175 points along the retreating ice margin during deglaciation. This decreased substantially over

1176 time, with a few instances of increased accumulation in the late Holocene associated with

1177 periods of renewed ice advance (Davies et al., 2011; Evans et al., 2002; Kempf et al., 2013).

1178 Sediment isopach thicknesses vary as a function of retreat rate, but in several examples the total

1179 sediment flux during deglaciation derived from isopachs argues for greatly elevated flux during

1180 retreat relative to the present (Hogan et al, 2012). For many marine-terminating systems from

1181 Alaska to East Greenland, the sedimentary record does support the hypothesis that retreat of the 
1182 ice margin results in elevated glacigenic sediment production that may reflect an increased ice

1183 flux during deglaciation. For polar iceberg-dominated systems of Antarctica, where sediment

1184 fluxes are modulated by floating ice shelves and/or sea ice, there are relatively insufficient data

1185 at this time to quantitatively resolve how deglaciation influences glacigenic sediment production

1186 and sediment release at the grounding line.

1187

\subsubsection{Quaternary glacial-interglacial cycles}

1189 The distinctive trough-bank morphology of high latitude continental shelves is a

1190 testament to prevalence of ice in shaping glacigenic sinks over Pleistocene timescales. Ice

1191 streaming and rapid calving maintain a high ice flux through the S2S system that is capable of

1192 eroding and reshaping both bedrock and glacigenic strata (Livingstone et al., 2012). Advances in

1193 marine geophysics and swath bathymetry have allowed us to map at high spatial resolution the

1194 flow of ice across these regions, documenting the dispersal pathways from source to sink over

1195 orbital timescales (Section 3). Establishing glacial sediment fluxes over the same timescales has

1196 proven more challenging, however, because ice advance through the transfer zone removes prior

1197 strata (Berger et al., 2008a; DaSilva et al., 1997; Powell and Cooper, 2002; Wellner et al., 2006).

1198 Consequently, the most complete stratigraphic record of glacial-interglacial ice dynamics is

1199 found beyond the continental shelf break. To first order, former ice extents can be determined

1200 from the binary, proxy sedimentary records found in gravity-flow deposits and IRD

1201 accumulating on the continental slope and in deeper basins (Auffret et al., 2002; Cofaigh et al.,

1202 2004; Hendy and Cosma, 2008; Davies et al., 2011; Dowdeswell et al., 1998; Nielsen et al.,

1203 2005; Rebesco et al., 2006; Patterson et al., 2014; Simon et al., 2014). Further establishing the

1204 ice flux dynamics from glacigenic sediment volumes requires spatially distributed seismic 
1205 reflection data linked to a chronology that is based on a long drill-core record (e.g., Fig. 14;

1206 Dowdeswell et al., 2010; Nygård et al., 2007; Reece et al., 2011; Vorren and Laberg, 1997).

1207 The sedimentary record of ice extent on Quaternary time scales is commonly established

1208 from IRD and other sedimentologic/geophysical proxies (Section 3). The challenges associated

1209 with developing glacial-interglacial chronologies in high-latitude sediments can be overcome by

1210 the combined use of multiple chronometers (Fig. 15; Alexanderson and Murray, 2012; Fuchs and

1211 Owen, 2008; Hillenbrand et al., 2010b; Simon et al., 2012; Brachfeld, et al., 2003; Stoner et al.,

1212 2000; Hendy and Cosma, 2008; Davies et al., 2011; Praetorius and Mix, 2014). Where

1213 distinctive bedrock geology is present, the relative contributions of glacially eroded sediments

1214 from different ice sources can be established through temporal analyses of sediment provenance

1215 (Andrews et al., 2014; Andrews and Vogt, 2014; Cook et al., 2014; Reyes et al., 2014; Simon et

1216 al., 2014; Pierce, et al., 2014; Flowerdew et al., 2012, 2013; Bailey et al., 2013). For example,

1217 several attempts have been made to integrate the numerous glacigenic, seismic reflection, and

1218 proxy records of ice sheet extent in the Barents-Kara sea region (Ingolfsson and Landvik, 2013;

1219 Jakobsson et al., 2014; Mangerud et al., 1998; Svendsen et al., 2004). However, as Ingolfosson

1220 and Landvik (2014) point out, these attempts to synthesize so many different datasets, each with

1221 their own temporal and spatial resolution, result in a glacial history that is a compromise and

1222 often does not match with local stratigraphic records. However, the benefit of this approach is

1223 that the driving mechanisms of ice dynamics (climate, oceanography, sea level) can be explored

1224 and tested against observations.

1225 In contrast, a more simplified view of ice dynamics can be developed from a single,

1226 central location that integrates the spatial and temporal variability of Quaternary ice sheet

1227 dynamics, such as that done by Simon et al. (2014) in Baffin Bay (Fig. 15). Using a multiproxy 
1228 approach from one distal, deep basin, they document variable glacigenic sediment production

1229 from the northeastern Laurentide, southern Innuitian and western Greenland ice margins over the

1230 last $115 \mathrm{ka}$. Contrary to the hypothesized high (glacial advance)-low (glacial maximum)-high

1231 (glacial retreat) sediment flux expected over a full glacial-interglacial cycle (Fig. 2B), the highest

1232 sediment accumulation rates were found during the MIS 1-2 deglacial transition, associated with

1233 elevated input from the Laurentide and southern Innuitian ice sheets, while sediment delivery

1234 from the fast-flowing ice stream in the Uummannaq Trough dominated the LGM period from

$1235 \sim 32$ to $\sim 16 \mathrm{ka}$.

1236 It can be argued that a temporal examination of sediment fluxes at a single site may not

1237 capture the total sediment flux generated from the source because of variable sediment routing to

1238 the sink (Jerolmack and Sadler, 2007; Gilbert et al., 2002). Adequately testing the high-low-high

1239 sediment flux scenario for a full glacial-interglacial cycle requires a) chronologically constrained

1240 seismic reflection data and b) a closed-system sink (i.e., all sediment delivered to the sink can be

1241 accounted for) over the timescale of interest. However, glaciated continental-margin settings

1242 present tremendous logistical and analytical challenges for collecting such geophysical data. It is

1243 difficult to recover sediment from diamicts by conventional drilling or to develop chronologies

1244 from barren sediments. Accordingly, there are few examples where even parts of the glacial-

1245 interglacial cycle can be examined at a temporal resolution equal to the response time of the ice.

1246 The predominance of cross-margin troughs on high-latitude margins suggests that ice streams are

1247 the principal mass dispersal pathways, and offer some of the best geographic locations to

1248 quantify mass fluxes over full glacial cycles (Vorren and Laberg, 1997). One notable example of

1249 attempting to quantify such a system is the work by Nygård et al., (2007), who used a dense

1250 seismic reflection network with millennial-scale age control to document the sediment flux at the 
1251 outlet of the Norwegian Channel ice stream, within the 100-kyr cycle (Fig. 15). Extremely high

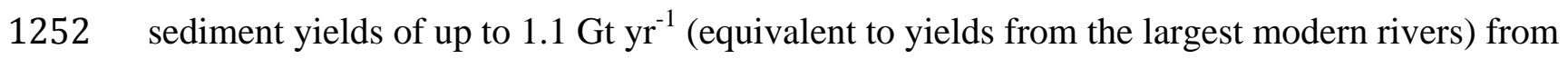

1253 glacigenic debris flows persisted for a short time between 20 to $19 \mathrm{ka}$, suggesting that the ice

1254 stream was highly dynamic during this period. Estimated ice stream velocities associated with

1255 this high flux were 1.3-2.7 $\mathrm{km} \mathrm{yr}^{-1}$. Assuming a transport distance from source to sink of 300-

$1256600 \mathrm{~km}$, the potential transfer time of the signal from the upper reaches of the source was equal

1257 to, or slightly faster than, the duration of the event (Nygård et al., 2007).

1258 Another notable example of integrating geophysical, sedimentological, and

1259 chronstratigraphic approaches to establish the erosive dynamic state of ice is by Laberg et al.

1260 (2009). They examined the sedimentary record produced in Vestfjorden, a former major ice

1261 stream of the northwestern Fennoscandian Ice Sheet (Boulton et al., 2001; Ottesen et al., 2005).

1262 The chronostratigraphy is relatively well established for the latest glacial cycle ( $\sim 35-10 \mathrm{ka}$;

1263 Andersen, 1975; Lauritzen, 1991; Olsen et al., 2001; Baumann et al., 1995; Dahlgren and

1264 Vorren, 2003; Bergstrøm et al., 2005). Significant erosion of $>100 \mathrm{~m}$ of unconsolidated

1265 sediments was observed in the outer part of the fjord during the LGM, and it is believed that the

1266 majority of erosion occurred under temperate bed conditions in the lower tributaries of the ice

1267 stream (Stroeven et al., 2002). The resultant sediment volume that accumulated between 26-18

1268 kya (the limit of their temporal resolution) equates to an average erosion rate of $1.7 \mathrm{~mm} \mathrm{yr}^{-1}$ and

1269 a glacigenic sediment discharge of $>10^{8}$ tons $\mathrm{yr}^{-1}$, which is comparable to modern glacifluvial

1270 systems in Alaska (Jaeger et al., 1998) yet an order of magnitude less than that observed by

1271 Nygård et al. (2007). The lack of a high-temporal-resolution chronostratigraphy directly tied to

1272 the seismic-reflection dataset in the Laberg et al. (2009) study precluded the ability to determine 
1273 if the sediment flux was limited to a very short time period during the maximum ice extent, as

1274 was done by Nygård et al. (2007) (e.g., Fig. 14).

1275 The studies by Nygård et al. (2007) and Laberg et al. (2009) illustrate the need to capture

1276 and date the full seismic volume associated with an ice stream cycle from source to sink if the

1277 goal is to use sediment fluxes as a means of partitioning glacigenic sediment production through

1278 time (Fig. 14). While these two studies document sediment fluxes within a 100-kyr glacial-

1279 interglacial cycle with relatively high temporal fidelity, additional examples integrating seismic-

1280 and chrono stratigraphy exist where sediment fluxes have been determined at lower temporal

1281 resolution for the LGM (Dahlgren et al., 2005; Knies et al., 2009; Dowdeswell et al., 2010;

1282 Laberg et al., 2010; Laberg and Vorren, 1996; Nielsen et al., 2005; Vorren et al., 1988).

1283 Although the stratigraphic record over a glacial cycle has the potential to be more

1284 volumetrically complete in deep sea basins than in shelf and fjord settings (Elverhoi et al.,

1285 1998b; Laberg et al., 2009), care must be taken in interpreting changes in sediment volumes as a

1286 reflection of the dynamic state of the ice. Seismic isopachs from glacially influenced deep-water

1287 basins can be interpreted to track the mode of dispersal and its relation to ice extent (Fig. 16;

1288 Taylor et al., 2002b). In the Norwegian and Lofoten deep-sea basins during the LGM (30-10 ka),

1289 sediment fluxes were dominated by large-scale submarine mass failures eroding pre-Quaternary

1290 strata (Fig. 16; Dowdeswell et al., 1996; Vorren et al., 1998; Dowdeswell and Siegert, 1999;

1291 Taylor et al., 2002b). Although pelagic, hemipelagic, and glacimarine processes were active over

1292 a glacial-interglacial cycle, they represented only $10 \%$ of the total deep-water sediment volume.

1293 In these settings, large-scale mass failure deposits may dominate the stratigraphic record, but the

1294 smaller glacigenic debris flows and glacimarine fluxes that could be used to constrain ice flux 
1295 dynamics (e.g., Nygård et al., 2007) comprise a greatly reduced fraction of the record (Figs.

1296 11,15; Taylor et al., 2002b; King et al 1998).

1297 In addition to core-based sediment accumulation rates or seismic reflection isopachs on

1298 continental shelves and slopes, subaqueous landforms provide another high-resolution record of

1299 ice dynamics. Transverse ridges and/or morainal banks found from temperate to polar settings

1300 are interpreted as seasonal/annual re-advances of the terminus (Fig. 10), and the spacing of these

1301 features provides a proxy for the rate of terminus retreat (Domack et al., 1999; Baeten et al.,

1302 2010; Boulton, 1986; Boulton et al., 1996; Ottesen and Dowdeswell, 2006, 2009; Ottesen et al.,

1303 2008a; Kempf et al., 2013; Livingstone et al., 2012; Shipp et al., 2002; Dowdeswell et al., 2008b;

1304 Cofaigh et al., 2008). Some grounding zone wedges are observed in Antarctic troughs where

1305 retreat rates during deglaciation were estimated to be rapid, and thus the sediment flux to the

1306 terminus must have been correspondingly high for them to form (Livingstone et al., 2012;

1307 Kilfeather et al., 2010). Perhaps the best-constrained record of the variability between ice

1308 dynamics and sediment fluxes on Antarctic shelves is from the eastern Ross Sea, where Bart and

1309 Owolana (2012) were able to develop a detailed chronology of sediment fluxes for a prominent

1310 grounding zone wedge (Fig. 17). Fluxes were partitioned between sediment recycled during re-

1311 advance and sediment contemporaneously eroded from the drainage basin, with the highest

1312 sediment fluxes during the penultimate interglacial and in the LGM.

1313

1314 4.4 Modeling ice dynamics and sediment fluxes to the sink

1315

1316 The logistical and chronological challenges of data collection in high-latitude margins

1317 currently limit our ability to relate ice flux dynamics and sediment production. Accordingly, a 
1318 forward modeling approach similar to the numerical models used to quantify glacial erosion rates

1319 and topographic development (Section 2.2.3) provides another means to assess the potential for

1320 the sedimentary record to contain a signal of ice dynamics and to establish testable hypotheses

1321 that can be constrained with future field programs.

1322 The leading example to date of a model relating climate, ice dynamics, and sediment

1323 production from source to sink is the one developed for a 30-kyr glacial cycle in the Barents-

1324 Kara Sea region as part of the European Science Foundation's QUEEN (Quaternary

1325 Environment of the Eurasian North) program (Dowdeswell and Siegert, 1999; Siegert et al.,

1326 1999; Siegert and Dowdeswell, 2002, 2004). The Siegert model is based on empirically

1327 established relationships between ice stream flow and deformation, and transport of water-

1328 saturated basal sediment (Alley, 1989). The model assumes that the topography at the start of the

1329 model run at $30 \mathrm{kya}$ is analogous to the modern topography, and the model accounts for the time-

1330 evolution of topography and sea level due to ice loading. Global estimates of eustatic sea-level

1331 (Fairbanks, 1989; Shackleton, 1987) are used to modify local sea-level at the calving front

1332 (Siegert and Dowdeswell, 1995) and empirically derived relationships are used to model calving

1333 rates (Pelto and Warren, 1991; Hughes, 1992). Ice dynamics in the model depend on air

1334 temperature and precipitation as a function of geographic location and altitude. The regional

1335 climate dynamics described by Pelto et al. (1990) are used to drive net surface mass balance of

1336 the ice sheet, and the ELA is related to temperature through a regional adiabatic lapse rate

1337 (Fortuin and Oerlemans, 1990). Temporal changes in regional air temperature are assumed to

1338 empirically follow global proxies of climate, with the atmospheric $\mathrm{CO}_{2}$ concentration used as the

1339 proxy of choice; little difference occurs if sea level or oxygen isotopic forcing functions are used

1340 instead (Siegert, 1993; Siegert and Dowdeswell, 1995). The validity of the ice dynamics output 
1341 from the model is tuned using an inverse approach by adjusting the climatic input to best match

1342 the known extent of ice over the 30-kyr period and to the glacio-isostatic response (Siegert et al.,

1343 1999; Landvik et al., 1998; Svendsen et al., 1999). The validity of the resulting sediment fluxes,

1344 however, remains unconstrained.

1345 The model predicts spatial and temporal evolution of sediment flux to the margin (Fig.

1346 18). In it, ice streams transported sediments to the margin from 27 to $16 \mathrm{ka}$ at a relatively

1347 constant rate, with maximum delivery around $\sim 15 \mathrm{ka}$ associated with rising sea level that

1348 stimulated increased ice velocity and sediment transfer rate within the ice streams to the trough

1349 mouths (Fig. 18). Sediment volumes produced by the model compare favorably with the total

1350 volume inferred from seismic records of the Bear Island and Storfjorden fans. Sensitivity

1351 experiments show that adjustments to model environmental inputs or dynamics of sediment

1352 generation at the bed using the chosen empirical relationships do not significantly affect their

1353 sediment flux results.

$1354 \quad$ Higher spatial resolution models have been attempted with variable success in matching

1355 known ice dynamics. Kirchner et al. (2011b) modeled ice dynamics within the subdomain of

1356 Svalbard using a zero-order force balance where the ice surface velocities are proportional to the

1357 ice surface gradient and the ice thickness. They compared their results of ice velocity to the

1358 reconstructions of Svalbard paleo-ice streams by Ottesen et al. (2007). In contrast to the simpler

1359 Siegert model, ice streams were created where expected under full LGM conditions depending

1360 on whether LGM or present topography is used as a boundary condition. However, a high-

1361 resolution $(5 \mathrm{~km})$ numeric ice-sheet model constraining past ice dynamics in the Antarctic

1362 Peninsula was able to re-create both the ice sheet thickness and the flow directions of the major

1363 outlets and ice streams (Golledge et al., 2013; Cofaigh et al., 2014). For most other modeling 
1364 studies of glaciated regions, however, the coupling of Global Circulation Models (GCMs) with

$13653 \mathrm{D}$ thermomechanical ice sheet models to reconstruct paleo-ice sheet dynamics have failed to

1366 reproduce the geologic evidence of former ice extent, because ice sheet dynamics appear to be

1367 highly sensitive to the downscaling of global climate to the "local" ice sheet (Kirchner et al.,

1368 2011a). Improving coupled GCM-ice sheet dynamics is clearly needed, and requires developing

1369 higher-spatial-resolution ice sheet models with bidirectional ice sheet-atmosphere feedbacks,

1370 improved treatment of the surface mass balance, and more precise regional climate data and

1371 paleoclimate reconstructions (Kirchner et al., 2011a).

1372

\section{5. Conclusions and Future Directions}

1374

1375

The ultimate goal of studying a glacial source-to-sink system is to relate changing

1376 boundary conditions with the ice response and the sedimentary record. Documenting the impact

1377 of ice on the landscape is a fundamental component of Quaternary geomorphology. Yet, modern

1378 glacial environments remain amongst the most logistically challenging environments in which to

1379 try to study the processes that generate and transfer sediment from the landscape to its sink and

1380 to provide a modern analogue for Quaternary landscape change. However, some of these

1381 processes are well enough constrained that predictive relationships can be demonstrated. In this

1382 review, we have highlighted those processes of sediment generation and transfer that are well

1383 understood in both time and space, and those that remain poorly constrained and where further

1384 focus is needed. We recognize that the dynamic state of the ice is viewed differently between the

1385 communities studying the source (i.e., glaciology and glacial geomorphology communities) and

1386 the sink (i.e., Quaternary and marine geology communities). For the former, the ice flux and 
1387 mass response to climate change are of most interest, while for the latter, the emphasis has been

1388 on documenting temporal and spatial changes in ice extent, which defines the boundary

1389 conditions that influence ice sheet development, but does not necessarily elucidate the ice flux.

1390 Observations from contemporary glaciated systems, primarily through marine geophysics

1391 (swath bathymetry, seismic), geochronology, and advances in sedimentary provenance, have

1392 proven instrumental in establishing genetic relationships. However, to interpret the dynamic

1393 state of the ice, the sedimentary signal must be resolved in terms of mass fluxes of characteristic

1394 glacial facies. Doing so requires chronological control at the timescale of the ice response

1395 function, which fundamentally limits the types of climate forcing that can be evaluated.

1396 Establishing absolute rates of sediment transfer is easiest at annual timescales in modern ice-

1397 proximal settings, but becomes increasing difficult for the Pleistocene because of reduced

1398 chronometric precision. Moreover, to isolate the glacial/climatic signal in the sink record, it is

1399 necessary to account for transfer mechanisms from ice-proximal (fjord) to ice-distal (deep sea)

1400 locales that complicate the signal, e.g., mass redistribution, gravity flows, ice rafting, and ocean

1401 circulation.

1402 Advancements in our understanding of the mechanics of glacial source-to-sink systems

1403 will be predicated upon the collection and examination of additional sedimentary records that

1404 were deposited under a variety of climatic and ice flux boundary conditions to establish sediment

1405 fluxes that can be tied to evolving ice dynamics. Documenting the relative roles of the glacier

1406 thermal regime and ice dynamics on sediment production and strata formation should be a

1407 fundamental goal of future research in Quaternary geomorphology, glaciology, and glacial

1408 sedimentology. We conclude by offering some potential avenues for future studies that can

1409 advance the field in the coming decade. 


\section{Deriving erodibility metrics for landscape evolution}

1412 A major challenge in understanding the role of glacial erosion in modifying the earth's

1413 surface, and in producing sediment, is the tuning of an 'erosion rule' for given climatic inputs

1414 that is applicable over the long periods required for the development of topography. We know

1415 that climate dictates the ice flux and thus the geomorphic work done by the ice generating the

1416 sedimentary mass flux signal, and that the most work occurs in fast moving ice and in the

1417 presence of meltwater, through temperate outlet glaciers and ice streams. However, while

1418 glaciers wax and wane, the degree to which subglacial regions are subject to fast ice flow and

1419 erosion is still debated. Moreover, the proportion of glacier motion due to basal sliding, which

1420 depends on a number of factors including bed type, water pressure fluctuations at the bed, and

1421 ice temperature, will vary significantly over both time and space, and likely varies by orders of

1422 magnitude over glacial-interglacial cycles. Additional measurements of glacial sediment yields

1423 over a range of climatic settings and parameters including varying substrate lithology, ice flux,

1424 ice temperature and meltwater discharge rates are required to better constrain the erosion

1425 parameter space and its evolution over glacial cycles. These can help address the outstanding

1426 question as to the erosive versus protective nature of ice.

1428 Chronostratigraphic control of geomorphic and seismic stratigraphic features

1429 Remotely sensed data have greatly expanded our view of the role of ice in shaping

1430 Quaternary landscapes. Radar-based ice thickness measurements, LIDAR, and multibeam

1431 bathymetry have revolutionized the mapping of glacigenic morphologic features. High-resolution

1432 multi-channel seismic reflection and higher-resolution CHIRP/TOPAS $3.5 \mathrm{kHz}$ reflection 
1433 profiles give detailed subsurface images of glacimarine strata. For both surface and subsurface

1434 mapping, chronostratigraphic control is frequently lacking, often due to inability to collect long

1435 cores or develop chronologies for collected strata. Sampling that provides more precise

1436 chronological control of stratigraphic horizons is required to address the glacial response to

1437 external forcing. New developments in scientific drilling (e.g., ANDRILL, SHALDRIL, IODP)

1438 have made fundamental advances in recovery of these challenging strata. Novel chronologic

1439 tools have been developed for microfossil-barren strata, offering the potential for improved age

1440 control to maximize interpretation of existing geophysical data.

1441

1442 Deciphering local (autogenic) from regional/global (allogenic) controls on ice dynamics and

1443 sediment production.

1444 Regional topography is influenced by tectonics, glacioisostacy, and the balance between

1445 erosion and deposition. Topography in turn influences local climate, ice fluxes, accommodation

1446 for sediment accumulation, and sediment dispersal pathways. The relative importance of these

1447 different local influences on topography will vary in space and time. A major challenge is to

1448 interpret the signal of these influences from geophysical and sedimentary records. Examples of

1449 identifying allogenic climate signals from the sedimentary record exist for local basins, where all

1450 glacigenic sediment can be accounted for in mass budgets. A larger challenge is to scale up in

1451 space and time to address fundamental questions about the ability of the glacial sedimentary

1452 record to capture ice dynamics in light of potential autogenic controls. Recent and proposed

1453 scientific drilling of Pleistocene strata that establishes chronologies for interpreted seismic

1454 volumes and sediment dispersal pathways and rates will help address these challenges.

1455 
1457 Our observational dataset of active glacial processes has been collected entirely within a

1458 time of rapid climate change following a major Neoglacial (LIA) period. Short-lived interglacial

1459 periods such as the one we are experiencing today are atypical relative to the majority of the

1460 Pleistocene. Most Quaternary glacial landscapes likely formed under conditions quite different

1461 from the present. If the physics of glacial erosion and glacigenic sedimentation can be well

1462 established, particularly in polar settings that have not yet experienced rapid climate warming,

1463 this information should be transferrable to the past if the appropriate climatic boundary

1464 conditions are known. There is a need for more mechanistic-level studies that integrate the

1465 principal processes governing ice-sediment-ocean interactions over both short and long time

1466 periods, with the appropriate temporal resolution to examine the various response time functions.

1467 These processes should include subglacial sediment production and evacuation and how both

1468 water and sediment are routed through each component of a source-to-sink system.

\section{Acknowledgements}

1471 The final manuscript benefited greatly from patient, critical, and insightful reviews by Ellen

1472 Cowan, Roger LeB. Hooke, Edward King, and J.P. Walsh. JMJ recognizes the National Science

1473 Foundation (Grants OPP-0326926, OCE-0351043, OCE-1434402) for support of research in the

1474 topics of glacimarine sedimentation. MNK was supported by National Science Foundation grant

1475 OPP-0338371 and National Science and Engineering Research Council (NSERC) operating

1476 grants for research on glacial erosion. 


\section{$1477 \quad 6.0$ References}

1478 Agassiz, L., 1840. Etudes sur les glaciers. Neuchâtel, Switzerland.

1479 Alexanderson, H., Murray, A.S., 2012. Luminescence signals from modern sediments in a 1480 glaciated bay, NW Svalbard. Quat. Geochronology 10, 250-256.

1481 Alley, R.B., 1989. Water-Pressure Coupling of Sliding and Bed Deformation .2. Velocity1482 Depth Profiles. J. Glaciology 35, 119-129.

1483 Alley, R.B., Blankenship, D.D., Bentley, C.R., Rooney, S.T., 1987. Till Beneath Ice Stream-B

1484 .3. Till Deformation - Evidence And Implications. J. Geophys. Res.-Solid Earth and Planets 1485 92(B9), 8921-8929.

1486 Alley, R.B., Blankenship, D.D., Rooney, S.T., Bentley, C.R., 1989. Water pressure coupling of 1487 sliding and bed deformation. 3. Application to Ice Stream B, Antarctica. Journal of $1488 \quad$ Glaciology 35, 130-139.

1489 Alley, R. B., Cuffey, K. M., Evenson, E. B., Strasser, J. C., Lawson, D. E., Larson, G. J., 1997. 1490 How glaciers entrain and transport basal sediment: Physical constraints. Quaternary Science $1491 \quad$ Reviews 16, 1017-1038.

1492 Alley, R. B., Lawson, D. E., Larson, G. J., Evenson, E. B., Baker, G. S., 2003. Stabilizing 1493 feedbacks in glacier-bed erosion. Nature 424, 758-760.

1494 Alley, R.B., Anandakrishnan, S., Dupont, T.K., Parizek, B.R., Pollard, D., 2007. Effect of 1495 sedimentation on ice-sheet grounding-line stability. Science 315, 1838-1841.

1496 Anandakrishnan, S., Catania, G.A., Alley, R.B., Horgan, H.J., 2007. Discovery of till 1497 deposition at the grounding line of Whillans Ice Stream. Science 315, 1835-1838.

1498 Andersen, B.G., 1975. Glacial geology of northern Nord- land, North Norway. Norges

1499 Geologiske Undersøkelse 320, 1-74. 
1500 Anderson, J.B., 1999. Antarctic Marine Geology. Cambridge: Cambridge University Press. 289

1501 pp.

1502 Anderson, J.B., Kurtz, D.D., Domack, E.W., Balshaw, K.M., 1980. Glacial and Glacial

1503 Marine-Sediments of the Antarctic Continental-Shelf. Journal of Geology 88, 399-414.

1504 Anderson, J., Shipp, S. Lowe, A., Wellner, J. S., Mosola, A.B., 2002. The Antarctic Ice Sheet

1505 during the Last Glacial Maximum and its subsequent retreat history: a review. Quaternary

$1506 \quad$ Science Reviews 21, 49-70.

1507 Anderson, J.B., Conway, H., Bart, P.J., Witus, A.E., Greenwood, S.L., McKay, R.M., Hall,

1508 B.L., Ackert, R.P., Licht, K., Jakobsson, M., Stone, J.O., 2014. Ross Sea paleo-ice sheet

1509 drainage and deglacial history during and since the LGM. Quaternary Science Reviews 100,

$1510 \quad 31-54$

1511 Anderson, R. S., Anderson, S. P., 2010. Geomorphology: the mechanics and chemistry of 1512 landscapes. Cambridge University Press., 637 pp.

1513 Anderson, R. S., Anderson, S. P. MacGregor, K. R. Waddington, E. D. O’Neel, S. Riihimaki,

1514 C. A., Loso, M. G., 2004. Strong feedbacks between hydrology and sliding of a small alpine

1515 glacier. Journal of Geophysical Research 109(F3), 1-17, doi:10.1029/2004JF000120.

1516 Anderson, R. S., Molnar, P., Kessler, M. A., 2006. Features of glacial valley profiles simply

1517 explained. Journal of Geophysical Research: Earth Surface 111(F1) F01004,

1518 doi:10.1029/2005JF000344.

1519 Anderson, S.P., 2005. Glaciers show direct linkage between erosion rate and chemical

1520 weathering fluxes. Geomorphology 67,147-157, doi:10.1016/j.geomorph.2004.07.010. 
1521 Andreassen, K., Winsborrow, M., 2009. Signature of ice streaming in Bjornoyrenna, Polar

1522 North Atlantic, through the Pleistocene and implications for ice-stream dynamics. Annals of 1523 Glaciology 50, 17-26.

1524 Andresen, C.S., Straneo, F., Ribergaard, M.H., Bjørk, A.A., Andersen, T.J., Kuijpers, A., 1525 Nørgaard-Pedersen, N., Kjær, K.H., Schjøth, F., Weckström, K., Ahlstrøm, A.P., 2012.

1526 Rapid response of Helheim Glacier in Greenland to climate variability over the past century.

$1527 \quad$ Nature Geoscience 5, 37-41. doi:10.1038/ngeo1349.

1528 Andrews, J.T. 2000. Icebergs and iceberg rafted detritus (IRD) in the North Atlantic: Facts and 1529 assumptions. Oceanography 13,100-108, doi.org/10.5670/oceanog.2000.19.

1530 Andrews, J.T., Principato, S.M., 2002. Grain-size characteristics and provenance of ice1531 proximal glacial marine sediments. Geological Society London, Special Publications 203, $1532 \quad 305-324$.

1533 Andrews, J.T., Vogt, C., 2014. Source to sink: Statistical identification of regional variations in 1534 the mineralogy of surface sediments in the western Nordic Seas $\left(58^{\circ} \mathrm{N}-75^{\circ} \mathrm{N} ; 10^{\circ} \mathrm{W}-40^{\circ} \mathrm{W}\right)$. $1535 \quad$ Marine Geology 357, 151-162.

1536 Andrews, J.T., Domack, E.W., Cunningham, W.L., Leventer, A., Licht, K.J., Jull, A.J.T., 1537 DeMaster, D.J., Jennings, A.E., 1999. Problems and possible solutions concerning 1538 radiocarbon dating of surface marine sediments, Ross Sea, Antarctica. Quaternary Research $1539 \quad 52,206-216$.

1540 Andrews, J.T., Bigg, G.R., Wilton, D.J., 2014. Holocene ice-rafting and sediment transport 1541 from the glaciated margin of East Greenland (67-70 degrees $\mathrm{N}$ ) to the $\mathrm{N}$ Iceland shelves: 1542 detecting and modelling changing sediment sources. Quaternary Science Reviews 91, 2041543217. 
1544 Ashley, G.M., Smith, N.D., 2000. Marine sedimentation at a calving glacier margin. Geological 1545 Society of America Bulletin 112, 657-667.

1546 Auffret, G., Zaragosi, S., Dennielou, B., Cortijo, E., Van Rooij, D., Grousset, F., Pujol, C.,

1547 Eynaud, F., Siegert, M., 2002. Terrigenous fluxes at the Celtic margin during the last glacial $1548 \quad$ cycle. Marine Geology 188, 79-108.

1549 Austin, W.E.N., Bard, E., Hunt, J.B., Kroon, D. and Peacock, J.D., 1995. The C-14 Age of the

1550 Icelandic Vedde Ash - implications for Younger-Dryas marine reservoir age corrections. $1551 \quad$ Radiocarbon 37, 53-62.

1552 Baeten, N.J., Forwick, M., Vogt, C., Vorren, T.O., 2010. Late Weichselian and Holocene 1553 sedimentary environments and glacial activity in Billefjorden, Svalbard. Special Publication 1554 344. London: The Geological Society of London, pp. 207-223.

1555 Bailey, I., Hole, G.M., Foster, G.L., Wilson, P.A., Storey, C.D., Trueman, C.N., Raymo, M.E., 1556 2013. An alternative suggestion for the Pliocene onset of major northern hemisphere 1557 glaciation based on the geochemical provenance of North Atlantic Ocean ice-rafted debris. 1558 Quaternary Science Reviews 75, 181-194. doi:10.1016/j.quascirev.2013.06.004

1559 Balco, G., 2011. Contributions and unrealized potential contributions of cosmogenic-nuclide 1560 exposure dating to glacier chronology, 1990-2010. Quaternary Science Reviews 30, 3-27.

1561 Balco, G., Rovey, C. W., 2010. Absolute chronology for major Pleistocene advances of the 1562 Laurentide Ice Sheet. Geology 38, 795-798.

1563 Ballantyne, C.K., 2002. Paraglacial geomorphology. Quaternary Science Reviews 21, 19352017.

1565 Barclay, D.J., Wiles, G.C., Calkin, P.E., 2009. Holocene glacier fluctuations in Alaska.

1566 Quaternary Science Reviews 28, 2034-2048. 
1567 Barrie, J.V., Conway, K.W., 2002. Contrasting glacial sedimentation processes and sea-level

1568 changes in two adjacent basins on the Pacific margin of Canada. Geological Society,

1569 London, Special Publications 203, 181-194.

1570 Barrie, J.V., Bornhold, B.D., Conway, K.W., Luternauer, J.L., 1991. Surficial geology of the

1571 northwestern Canadian continental-shelf. Continental Shelf Research 11, 701-715.

1572 Bart, P.J., Owolana, B., 2012. On the duration of West Antarctic Ice Sheet grounding events in

1573 Ross Sea during the Quaternary. Quaternary Science Reviews 47: 101-115.

1574 Bartholomaus, T. C., Anderson, R. S., Anderson, S. P., 2007. Response of glacier basal motion

1575 to transient water storage. Nature Geoscience 1, 33-37.

1576 Bartholomew, I., Nienow, P., Mair, D., Hubbard, A., King, M.A., Sole, A., 2010. Seasonal

1577 evolution of subglacial drainage and acceleration in a Greenland outlet glacier. Nature

$1578 \quad$ Geoscience 3, 408-411, doi:10.1038/ngeo863.

1579 Batchelor, C.L., Dowdeswell, J.A., 2014. The physiography of High Arctic cross-shelf troughs.

1580 Quaternary Science Reviews 92, 68-96.

1581 Batchelor, C.L., Dowdeswell, J.A. and Hogan, K.A., 2011. Late Quaternary ice flow and

1582 sediment delivery through Hinlopen Trough, Northern Svalbard margin: Submarine

1583 landforms and depositional fan. Marine Geology 284, 13-27.

1584 Batchelor, C.L., Dowdeswell, J.A., Pietras, J.T., 2013. Seismic stratigraphy, sedimentary

1585 architecture and palaeo-glaciology of the Mackenzie Trough: evidence for two Quaternary

1586 ice advances and limited fan development on the western Canadian Beaufort Sea margin.

1587 Quaternary Science Reviews 65, 73-87. 
1588 Batchelor, C.L., Dowdeswell, J.A., Pietras, J.T., 2014. Evidence for multiple Quaternary ice

1589 advances and fan development from the Amundsen Gulf cross-shelf trough and slope,

1590 Canadian Beaufort Sea margin. Marine and Petroleum Geology 52, 125-143.

1591 Baumann, K.-H., Lackschewitz, K.S., Mangerud, J., Spielhagen, R.F., Wolf-welling, T.C.W.,

1592 Henrich, R., Kassens, H., 1995. Reflection of Scandinavian ice sheet fluctuations in

1593 Norwegian Sea sediments during the past 150,000 years. Quat. Res. 43, 185-197.

1594 Beaud, F., Flowers, G. E., Pimentel, S., 2014. Seasonal-scale abrasion and quarrying patterns

1595 from a two-dimensional ice-flow model coupled to distributed and channelized subglacial

1596 drainage. Geomorphology 219, 176-191.

1597 Becker, R.A., Tikoff, B., Riley, P.R., Iverson, N.R., 2014. Preexisting fractures and the

1598 formation of an iconic American Inadscape: Tuolomne Meadows, Yosemite National Park,

1599 USA. GSA Today, 24, 4-10. doi: 10.1130/GSATG203A.1.

1600 Benn, D. I. and Evans, D.J.A., 2010. Glaciers and Glaciation. 2nd Edition. London: Hodder

$1601 \quad$ Education. 734 pp.

1602 Benn, D.I., Warren, C.R., Mottram, R.H., 2007. Calving processes and the dynamics of calving

1603 glaciers. Earth-Science Reviews 82, 143-179.

1604 Bennett, M.R., 2003. Ice streams as the arteries of an ice sheet: their mechanics, stability and

1605 significance. Earth-Science Reviews 61, 309-339.

1606 Bentley, C.R., 1987. Antarctic Ice Streams - A Review. Journal of Geophysical Research-Solid

$1607 \quad$ Earth and Planets 92(B9), 8843-8858.

1608 Bentley, M.J., Cofaigh, C.O., Anderson, J.B., Conway, H., Davies, B., Graham, A.G.C.,

1609 Hillenbrand, C.D., Hodgson, D.A., Jamieson, S.S.R., Larter, R.D., Mackintosh, A., Smith,

1610 J.A., Verleyen, E., Ackert, R.P., Bart, P.J., Berg, S., Brunstein, D., Canals, M., Colhoun, 
E.A., Crosta, X., Dickens, W.A., Domack, E., Dowdeswell, J.A., Dunbar, R., Ehrmann, W.,

1612 Evans, J., Favier, V., Fink, D., Fogwill, C.J., Glasser, N.F., Gohl, K., Golledge, N.R.,

1613 Goodwin, I., Gore, D.B., Greenwood, S.L., Hall, B.L., Hall, K., Hedding, D.W., Hein, A.S.,

1614 Hocking, E.P., Jakobsson, M., Johnson, J.S., Jomelli, V., Jones, R.S., Klages, J.P.,

1615 Kristoffersen, Y., Kuhn, G., Leventer, A., Licht, K., Lilly, K., Lindow, J., Livingstone, S.J.,

1616 Masse, G., McGlone, M.S., McKay, R.M., Melles, M., Miura, H., Mulvaney, R., Nel, W.,

1617 Nitsche, F.O., O'Brien, P.E., Post, A.L., Roberts, S.J., Saunders, K.M., Selkirk, P.M.,

1618 Simms, A.R., Spiegel, C., Stolldorf, T.D., Sugden, D.E., van der Putten, N., van Ommen, T.,

1619 Verfaillie, D., Vyverman, W., Wagner, B., White, D.A., Witus, A.E., Zwartz, D. and

1620 Consortium, R., 2014. A community-based geological reconstruction of Antarctic Ice Sheet

1621 deglaciation since the Last Glacial Maximum. Quaternary Science Reviews 100: 1-9.

1622 Berger, A. L., Spotila, J. A., 2008. Denudation and deformation in a glaciated orogenic wedge:

1623 The St. Elias orogen, Alaska. Geology 36(7), 523-526.

1624 Berger, A.L., Gulick, S.P.S., Spotila, J.A., Upton, P., Jaeger, J.M., Chapman, J.B.,

1625 Worthington, L.A., Pavlis, T.L., Ridgway, K.D., Willems, B.A., McAleer, R.J., 2008a.

1626 Quaternary tectonic response to intensified glacial erosion in an orogenic wedge. Nature

1627 Geoscience 1, 793-799.

1628 Berger, A.L., Spotila, J.A., Chapman, J.B., Pavlis, T.L., Enkelmann, E., Ruppert, N.A.,

1629 Buscher, J.T., 2008b. Architecture, kinematics, and exhumation of a convergent orogenic

1630 wedge: A thermochronological investigation of tectonic-climatic interactions within the

1631 central St. Elias orogen, Alaska. Earth and Planetary Science Letters 270, 13-24.

1632 Berger, G.W., Ante, S., Domack, E., 2010. Luminescence from glacimarine sediment-trap

1633 samples at the Antarctic Peninsula. Quaternary Geochronology 5, 244-249. 
1634 Bergstrøm, B., Olsen, L., Sveian, H., 2005, The Tromsø- Lyngen glacial readvance (early

1635 Younger Dryas) at Hinnøya-Ofotfjorden, northern Norway. Norges Geologiske

$1636 \quad$ Undersøkelse Bulletin 445, 73-88.

1637 Bingham, R.G., King, E.C., Smith, A.M., Pritchard, H.D., 2010. Glacial geomorphology:

1638 Towards a convergence of glaciology and geomorphology. Progress in Physical Geography

$1639 \quad 34,327-355$.

1640 Bitz, C.M., Battisti, D.S., 1999. Interannual to decadal variability in climate and the glacier

1641 mass balance in Washington, western Canada, and Alaska. Journal of Climate 12, 3181-

$1642 \quad 3196$.

1643 Blum, M.D., Guccione, M.J., Wysocki, D., Robnett, P.C., 2000. Late Pleistocene evolution of

1644 the Mississippi valley, southern Missouri to Arkansas. Geological Society of America

1645 Bulletin 112, 221-235.

1646 Boldt, K.V., Nittrouer, C.A., Hallet, B., Koppes, M.N., Forrest, B.K., Wellner, J.S., Anderson,

1647 J.B., 2013. Modern rates of glacial sediment accumulation along a $15^{\circ} \mathrm{S}-\mathrm{N}$ transect in fjords

1648 from the Antarctic Peninsula to southern Chile. J. Geophys. Res. Earth Surf. 118, 1-17.

1649 doi:10.1002/jgrf.20145.

1650 Boulton, G.S., 1979. Process of glacial erosion on different substrata. Journal of Glaciology 23, $1651 \quad 15-37$.

1652 Boulton, G. S.,1986. Push-moraines and glacier-contact fans in marine and terrestrial

1653 environments. Sedimentology 33, 677-698.

1654 Boulton, G., Hagdorn, M., 2006. Glaciology of the British Isles Ice Sheet during the last glacial 1655 cycle: form, flow, streams and lobes. Quaternary Science Reviews 25, 3359-3390. 
1656 Boulton, G.S., Dongelmans, P., Punkari, M., Broadgate, M., 2001. Palaeogeology of an ice 1657 sheet through a glacial cycle: the European ice sheet through the Weichselian. Quaternary 1658 Science Reviews 20, 591-625.

1659 Boulton, G. S., Lunn, R., Vidstrand, P., Zatsepin, S., 2007. Subglacial drainage by 1660 groundwater-channel coupling, and the origin of esker systems: part 1-glaciological 1661 observations. Quaternary Science Reviews 26, 1067-1090.

1662 Box, J. E., Fettweis, X., Stroeve, J. C., Tedesco, M., Hall, D. K., Steffen, K., 2012. Greenland 1663 ice sheet albedo feedback: Thermodynamics and atmospheric drivers. The Cryosphere 6, $1664 \quad 821-839$.

1665 Boyd, B. L., Anderson, J. B., Wellner, J. S., Fernández, R. A., 2008. The sedimentary record of 1666 glacial retreat, Marinelli Fjord, Patagonia: Regional correlations and climate ties. Marine 1667 Geology 255, 165-178.

1668 Brachfeld, S., Domack, E., Kissel, C., Laj, C., Leventer, A., Ishman, S., Gilbert, R., 1669 Camerlenghi, A., Eglinton, L.B., 2003. Holocene history of the Larsen-A Ice Shelf 1670 constrained by geomagnetic paleointensity dating. Geology 31, 749-752.

1671 Braun, J., Zwartz, D., Tomkin, J. H., 1999. A new surface-processes model combining glacial 1672 and fluvial erosion. Annals of Glaciology 28, 282-290.

1673 Briner, J.P., Kaufman, D.S., 2008. Late Pleistocene mountain glaciation in Alaska: key 1674 chronologies. Journal of Quaternary Science 23, 659-670.

1675 Briner, J. P., Miller, G. H., Davis, P. T., Bierman, P. R., Caffee, M., 2003. Last Glacial 1676 Maximum ice sheet dynamics in Arctic Canada inferred from young erratics perched on 1677 ancient tors. Quaternary Science Reviews 22, 437-444. 
1678 Briner, J.P., Miller, G.H., Davis, P.T., Finkel, R.C., 2006. Cosmogenic radionuclides from 1679 fiord landscapes support differential erosion by overriding ice sheets. Geological Society of $1680 \quad$ America Bulletin 118, 406-420.

1681 Cai, J., Powell, R.D., Cowan, E.A., Carlson, P.R., 1997. Lithofacies and seismic-reflection 1682 interpretation of temperate glacimarine sedimentation in Tarr Inlet, Glacier Bay, Alaska.

1683 Marine Geology 143, 5-37.

1684 Carlson, P.R., Bruns, T.R., Molnia, B.F., Schwab, W.C., 1982. Submarine valleys in the 1685 northeatern Gulf of Alaska: Characteristics and probable origin. Marine Geology 47, $217-$ 1686242.

1687 Carlson, P.R., Molnia, B.F., Kittleson, S.C. and J.C., H., 1977. Distribution of bottom 1688 sediments on the continental shelf, northern Gulf of Alaska, Scale 1:500,000. Misc. Field 1689 Stud. Map MF-876, U.S. Geological Survey.

1690 Champagnac, J.D., Valla, P.G., Herman, F., 2014. Late-Cenozoic relief evolution under 1691 evolving climate: A review. Tectonophysics 614, 44-65.

1692 Chorley, R.J. 1973. The History of the Study of Landforms, or the Developments of 1693 Geomorphology. Methuen, London.

1694 Christoffersen, P., Tulaczyk, S., Behar, A., 2010. Basal ice sequences in Antarctic ice streams: 1695 exposure of past hydrological conditions and a principle mode of sedi- ment transfer. 1696 Journal of Geophysical Research 115, F03034.

1697 Church, M., Ryder, J.M., 1972. Paraglacial sedimentation: A consideration of fluvial processes 1698 conditioned by glaciation. Geological Society of America Bulletin 83, 3059-3072.

1699 Church, M., Slaymaker, O., 1989. Disequilibrium of Holocene sediment yield in glaciated $1700 \quad$ British Columbia. Nature 337, 452-454. 
1701 Chutko, K.J., Lamoureux, S.F., 2008. Identification of coherent links between interannual

1702 sedimentary structures and daily meteorological observations in Arctic proglacial lacustrine

1703 varves: potentials and limitations. Canadian Journal of Earth Sciences 45, 1-13.

1704 Clark, P.U., Pisias, N.G., 2000. Interpreting iceberg deposits in the deep sea. Science 290, 51-

170551.

1706 Cofaigh, C.Ó., 2012. Ice sheets viewed from the ocean: the contribution of marine science to 1707 understanding modern and past ice sheets. Philosophical Transactions of the Royal Society 1708 a-Mathematical Physical and Engineering Sciences 370, 5512-5539.

1709 Cofaigh, C.Ó, Dowdeswell, J.A., 2001. Laminated sediments in glacimarine environments:

1710 diagnostic criteria for their interpretation. Quaternary Science Reviews 20, 1411-1436.

1711 Cofaigh, C.Ó., Dowdeswell, J.A., Grobe, H., 2001. Holocene glacimarine sedimentation, inner

1712 Scoresby Sund, East Greenland: the influence of fast-flowing ice-sheet outlet glaciers.

$1713 \quad$ Marine Geology 175, 103-129.

1714 Cofaigh, C.Ó., Dowdeswell, J.A., Pudsey, C.J., 2001. Late quaternary iceberg rafting along the

1715 Antarctic Peninsula continental rise and in the Weddell and Scotia Seas. Quaternary

$1716 \quad$ Research 56, 308-321.

1717 Cofaigh, C.Ó., Taylor, J., Dowdeswell, J.A., Rosell-Mele, A., Kenyon, N.H., Evans, J.,

1718 Mienert, J., 2002. Sediment reworking on high-latitude continental margins and its

1719 implications for palaeoceanographic studies: insights from the Norwegian-Greenland Sea.

1720 Geological Society, London, Special Publications 203, 325-348.

1721 Cofaigh, C.Ó., Taylor, J., Dowdeswell, J.A., Pudsey, C.J., 2003. Palaeo-ice streams, trough

1722 mouth fans and high-latitude continental slope sedimentation. Boreas 32, 37-55. 
1723 Cofaigh, C.Ó., Dowdeswell, J.A., Evans, J., Kenyon, N.H., Taylor, J., Mienert, J., Wilken, M.,

1724 2004. Timing and significance of glacially influenced mass-wasting in the submarine

1725 channels of the Greenland Basin. Marine Geology 207, 39-54.

1726 Cofaigh, C.Ó., Dowdeswell, J.A., Allen, C.S., Hiemstra, J.F., Pudsey, C.J., Evans, J., Evans,

1727 D.J.A., 2005. Flow dynamics and till genesis associated with a marine-based Antarctic

1728 palaeo-ice stream. Quaternary Science Reviews 24, 709-740.

1729 Cofaigh, C.Ó., Evans, J., Dowdeswell, J.A., Larter, R.D., 2007. Till characteristics, genesis and

1730 transport beneath Antarctic paleo-ice streams. Journal of Geophysical Research-Earth

$1731 \quad$ Surface 112(F3).

1732 Cofaigh, C.Ó., Dowdeswell, J.A., Evans, J., Larter, R.D., 2008. Geological constraints on

1733 Antarctic palaeo-ice-stream retreat. Earth Surface Processes and Landforms 33, 513-525.

1734 Cofaigh, C.Ó., Dunlop, P. and Benetti, S., 2012. Marine geophysical evidence for Late

1735 Pleistocene ice sheet extent and recession off northwest Ireland. Quaternary Science

$1736 \quad$ Reviews 44, 147-159.

1737 Cofaigh, C.Ó., Andrews, J.T., Jennings, A.E., Dowdeswell, J.A., Hogan, K.A., Kilfeather, A.A.

1738 and Sheldon, C., 2013. Glacimarine lithofacies, provenance and depositional processes on a

1739 West Greenland trough-mouth fan. Journal of Quaternary Science 28,13-26.

1740 Cofaigh, C.Ó., Davies, B.J., Livingstone, S.J., Smith, J.A., Johnson, J.S., Hocking, E.P.,

1741 Hodgson, D.A., Anderson, J.B., Bentley, M.J., Canals, M., Domack, E., Dowdeswell, J.A.,

1742 Evans, J., Glasser, N.F., Hillenbrand, C.D., Larter, R.D., Roberts, S.J., Simms, A.R., 2014.

1743 Reconstruction of ice-sheet changes in the Antarctic Peninsula since the Last Glacial

1744 Maximum. Quaternary Science Reviews 100, 87-110. 
1745 Cook, C.P., van de Flierdt, T., Williams, T., Hemming, S.R., Iwai, M., Kobayashi, M.,

1746 Jimenez-Espejo, F.J., Escutia, C., Gonzalez, J.J., Khim, B.-K., McKay, R.M., Passchier, S.,

1747 Bohaty, S.M., Riesselman, C.R., Tauxe, L., Sugisaki, S., Galindo, A.L., Patterson, M.O.,

1748 Sangiorgi, F., Pierce, E.L., Brinkhuis, H., Klaus, A., Fehr, A., Bendle, J.A.P., Bijl, P.K.,

1749 Carr, S.A., Dunbar, R.B., Flores, J.A., Hayden, T.G., Katsuki, K., Kong, G.S., Nakai, M.,

1750 Olney, M.P., Pekar, S.F., Pross, J., Rohl, U., Sakai, T., Shrivastava, P.K., Stickley, C.E.,

1751 Tuo, S., Welsh, K. and Yamane, M., 2014. Dynamic behaviour of the East Antarctic ice

1752 sheet during Pliocene warmth. Nature Geoscience 6, 765-769.

1753 Cook, S.J., Swift, D.A., 2012. Subglacial basins: Their origin and importance in glacial

$1754 \quad$ systems and landscapes. Earth-Science Reviews 115, 332-372.

1755 Cowan, E.A. and Powell, R.D., 1990. Suspended sediment transport and deposition of

1756 cyclically interlaminated sediment in a temperate glacial fjord, Alaska, U.S.A. In: J.A.

1757 Dowdeswell and J.D. Scourse (Editors), Glacimarine Environments: Processes and

1758 Sediments. Geological Society Special Publication, London, 75-89.

1759 Cowan, E.A., Powell, R.D., 1991. Ice-proximal sediment accumulation rates in a temperate

1760 glacial fjord, southeastern Alaska, in Glacial Marine Sedimentation: Paleoclimatic

1761 Significance, edited by J. B. Anderson and G. M. Ashley, Geological Society of America,

1762 Boulder, CO, p. 61-73.

1763 Cowan, E. A., Powell, R. D., Smith, N. D., 1988. Rainstorm-induced event sedimentation at the

1764 tidewater front of a temperate glacier. Geology 16, 409-412.

1765 Cowan, E.A., Cai, J., Powell, R.D., Clark, J.D., Pitcher, J.N., 1997. Temperate glacimarine

1766 varves: An example from Disenchantment Bay, Alaska. Journal of Sedimentary Research

$1767 \quad 67,536-549$. 
1768 Cowan, E.A., Cai, J., Powell, R.D., Seramur, K.C., Spurgeon, V.L., 1998. Modern tidal

1769 rhythmites deposited in a deep-water estuary. Geo-Marine Letters 18, 40-48.

1770 Cowan, E. A., Seramur, K. C., Cai, J., Powell, R. D., 1999. Cyclic sedimentation produced by

1771 fluctuations in meltwater discharge, tides and marine productivity in an Alaskan fjord.

1772 Sedimentology 46, 1109-1126.

1773 Cowan, E. A., Seramur, K. C., Powell, R. D., Willems, B. A., Gulick, S. P. S., Jaeger, J. M., 1774 2010. Fjords as temporary sediment traps: History of glacial erosion and deposition in Muir

1775 Inlet, Glacier Bay National Park, southeastern Alaska. Geological Society of America

$1776 \quad$ Bulletin 122,1067-1080, doi:10.1130/B26595.1.

1777 Cowan, E.A., Christoffersen, P., Powell, R.D., 2012. Sedimentological signature of a

1778 deformable bed preserved beneath an ice stream in a late Pleistocene glacial sequence, Ross

1779 Sea, Antarctica. Journal of Sedimentary Research 82, 270-282.

1780 Cowan, E. A., Christoffersen, P., Powell, R. D., Talarico, F. M., 2014. Dynamics of the late

1781 Plio-Pleistocene West Antarctic Ice Sheet documented in subglacial diamictites, AND-1B

1782 drill core. Global and Planetary Change 119, 56-70.

1783 Cowton, T., Nienow, P., Bartholomew, I., Sole, A., Mair, D., 2012. Rapid erosion beneath the 1784 Greenland Ice Sheet. Geology 40, 343-346.

1785 Creyts, T. T., Clarke, G. K., Church, M., 2013. Evolution of subglacial overdeepenings in 1786 response to sediment redistribution and glaciohydraulic supercooling. Journal of 1787 Geophysical Research: Earth Surface 118, 423-446.

1788 Crossen, K.J. and Lowell, T.V., 2010. Holocene history revealed by post-surge retreat; Bering 1789 Glacier forelands, Alaska. Special Paper - Geological Society of America 462, 235-250. 
1790 Cuffey, K. M., Conway, H., Hallet, B., Gades, A. M., Raymond, C.F., 1999. Interfacial water

1791 in polar glaciers and glacier sliding at $-17^{\circ} \mathrm{C}$, Geophysical Research Letters $26,751-754$,

1792 doi:10.1029/1999GL900096.

1793 Cuffey, K.M., Paterson, W.S.B., 2010. The Physics of Glaciers, 4th edition. Elsevier, New $1794 \quad$ York. 704 pp.

1795 Curran, K. J., Hill, P. S., Milligan, T. G., Cowan, E. A., Syvitski, J. P. M., Konings, S. M., 1796 2004. Fine-grained sediment flocculation below the Hubbard Glacier meltwater plume, 1797 Disenchantment Bay, Alaska. Marine Geology 203, 83-94.

1798 Dahlgren, K.I.T., Vorren, T.O., 2003, Sedimentary environment and glacial history during the 1799 last $40 \mathrm{ka}$ of the Vøring continental margin, mid-Norway. Marine Geology 193, 93-127, 1800 doi: $10.1016 / \mathrm{S} 0025-3227(02) 00617-5$.

1801 Dahlgren, K.I.T., Vorren, T.O., Laberg, J.S., 2002. Late Quaternary glacial development of the 1802 mid-Norwegian margin - 65 to 68 degrees N. Marine and Petroleum Geology 19, 1089$1803 \quad 1113$.

1804 Dahlgren, K.I.T., Vorren, T.O., Stoker, M.S., Nielsen, T., Nygard, A., Sejrup, H.P., 2005. Late 1805 Cenozoic prograding wedges on the NW European continental margin: their formation and 1806 relationship to tectonics and climate. Marine and Petroleum Geology 22, 1089-1110.

1807 DaSilva, J.L., Anderson, J.B., Stravers, J., 1997. Seismic facies changes along a nearly 1808 continuous 24 degrees latitudinal transect: the fjords of Chile and the northern Antarctic 1809 Peninsula. Marine Geology 143, 103-123.

1810 Davies-Walczak, M., Mix, A.C., Stoner, J.S., Southon, J.R., Cheseby, M., Xuan, C., 2014. Late 1811 Glacial to Holocene radiocarbon constraints on North Pacific Intermediate Water ventilation 1812 and deglacial atmospheric $\mathrm{CO}_{2}$ sources. Earth and Planetary Science Letters 397, 57-66. 
1813 Davies, M.H., Mix, A.C., Stoner, J.S., Addison, J.A., Jaeger, J., Finney, B., Wiest, J., 2011.

1814 The deglacial transition on the southeastern Alaska Margin: Meltwater input, sea level rise,

1815 marine productivity, and sedimentary anoxia. Paleoceanography 26, PA2223,

1816 doi:10.1029/2010PA002051.

1817 Davis, P.T., Menounos, B., Osborn, G., 2009. Holocene and latest Pleistocene alpine glacier

1818 fluctuations: a global perspective. Quaternary Science Reviews 28, 2021-2033.

1819 Delmas, M, Calvet, M., Gurnell, Y., 2009. Variability of Quaternary glacial erosion rates - A

1820 global perspective with special reference to the Eastern Pyrenees. Quaternary Science

$1821 \quad$ Reviews 28, 484-498.

1822 DeMaster, D. J., Nelson, T. M., Harden, S. L., Nittrouer, C.A., 1991. The cycling and

1823 accumulation of biogenic silica and organic carbon in Antarctic deep-sea and continental

1824 margin environments, Mar. Chem. 35, 489-502, doi:10.1016/S0304-4203(09)90039-1.

1825 Derbyshire, E., 2003. Loess, and the Dust Indicators and Records of Terrestrial and Marine

1826 Palaeoenvironments (DIRTMAP) database. Quaternary Science Reviews 22, 1813-1819.

1827 Deser, C., Holland, M., Reverdin, G., Timlin, M., 2002. Decadal variations in Labrador Sea ice

1828 cover and North Atlantic sea surface temperatures. Journal of Geophysical Research Oceans

$1829 \quad 107$, C5, 3-1-3-12.

1830 Desloges, J.R., Gilbert, R., Nielsen, N., Christiansen, C., Rasch, M., Ohlenschlager, R., 2002.

1831 Holocene glacimarine sedimentary environments in fiords of Disko Bugt, West Greenland.

1832 Quaternary Science Reviews 21, 947-963.

1833 DeWinter, I, Storms, J., Overeem, I., 2012. Numerical modeling of glacial sediment production

1834 and transport during deglaciation. Geomorphology 167-168, 102-114. 
1835 Dobson, M., O’Leary, L. R. Veart, M., 1998. Sediment delivery to the Gulf of Alaska: source 1836 mechanisms along a glaciated transform margin. In Stoker, M. S., Evans, D. and Cramp, A. 1837 (eds.): Geological Processes on Continental Margins: Sedimentation, Mass-Wasting and 1838 Stability. Geological Society, London, Special Publication 129, 43-66.

1839 Domack, E.W., 1990. Laminated terrigenous sediments from the Antarctic Peninsula; the role

1840 of subglacial and marine processes. In: J.A. Dowdeswell and J.D. Scourse (Editors),

1841 Glacimarine Environments: Processes and Sediments. Geological Society Special

1842 Publication, London, 91-103.

1843 Domack, E.W., Williams, C.R., 1990. Fine-structure and suspended sediment transport in three $1844 \quad$ Antarctic fjords. Antarctic Research Series 50, 71-89.

1845 Domack, E.W. Ishman, S.E., 1993. Oceanographic and physiographic controls on modern 1846 sedimentation within Antarctic fjords. Geological Society of America Bulletin 105, 1175$1847 \quad 1189$.

1848 Domack, E. W., McClennen, C.E., 1996. Accumulation of glacial marine sediments in fjords of 1849 the Antarctic Peninsula and their use as late Holocene paleoenvironmental indicators, $1850 \quad$ Antarctic Research Series 70, 135-154.

1851 Domack, E.W., Harris, P.T., 1998. A new depositional model for ice shelves, based upon 1852 sediment cores from the Ross Sea and the Mac. Robertson shelf, Antarctica. Annals of $1853 \quad$ Glaciology 27, 281-284.

1854 Domack, E.W., Foss, D.J.P., Syvitski, J.P.M., McClennen, C.E., 1994. Transport of suspended 1855 particulate matter in an Antarctic fjord: Marine Geology 121, 161-170.

1856 Domack, E. W., Jacobson, E. A., Shipp, S., Anderson, J. B., 1999. Sedimentologic and 1857 stratigraphic signature of the late Pleistocene/Holocene fluctuations of the West Antarctic 

$111,1486-1516$.

1860 Dowdeswell, J. A., 1995. Glaciers in the High Arctic and recent environmental change.

1861 Philosophical Transactions of the Royal Society of London. Series A: Physical and $1862 \quad$ Engineering Sciences 352, 321-334.

1863 Dowdeswell, J.A., Cromack, M., 1991. Behaviour of a glacier-derived suspended sediment 1864 plume in a small Arctic inlet. Journal of Geology 99,111-123.

1865 Dowdeswell, J.A., Siegert, M.J., 1999. Ice-sheet numerical modeling and marine geophysical 1866 measurement of glacier-derived sedimentation on the Eurasian Arctic continental margins. 1867 Geological Society of America Bulletin 111, 1080-1097.

1868 Dowdeswell, J.A., Bamber, J.L., 2007. Keel depths of modem Antarctic icebergs and 1869 implications for sea-floor scouring in the geological record. Marine Geology 243, 120-131.

1870 Dowdeswell, J.A., Fugelli, E.M.G., 2012. The seismic architecture and geometry of grounding1871 zone wedges formed at the marine margins of past ice sheets. Geological Society of $1872 \quad$ America Bulletin 124, 1750-1761.

1873 Dowdeswell, J.A. and Vásquez, M., 2013. Submarine landforms in the fjords of southern 1874 Chile: implications for glacimarine processes and sedimentation in a mild glacier-influenced 1875 environment. Quaternary Science Reviews 64, 1-19.

1876 Dowdeswell, J. A., Hamilton, G.S., Hagen, J.O., 1991. The duration of the active phase on 1877 surge-type glaciers: contrasts between Svalbard and other regions, J. Glaciol. 37, 388-400.

1878 Dowdeswell, J.A., Kenyon, N.H., Eleverhoi, A., Laberg, J.S., Hollender, F.J., Mienert, J., 1879 Siegert, M.J., 1996. Large-scale sedimentation on the glacier-influenced Polar North 
Atlantic margins: Long-range side-scan sonar evidence. Geophysical Research Letters 23, $3535-3538$.

1882 Dowdeswell, J. A., Elverhøi, A., Spielhagen, R., 1998. Glacimarine sedimentary processes and 1883 facies on the Polar North Atlantic margins. Quaternary Science Reviews 17, 243-272.

1884 Dowdeswell, J.A., Whittington, R.J., Jennings, A.E., Andrews, J.T., Mackensen, A.,

1885 Marienfeld, P., 2000. An origin for laminated glacimarine sediments through sea-ice build1886 up and suppressed iceberg rafting. Sedimentology 47, 557-576.

1887 Dowdeswell, J.A., Cofaigh, C.Ó, Taylor, J., Kenyon, N.H., Mienert, J. Wilken, M., 2002. On 1888 the architecture of high-latitude continental margins: the influence of ice-sheet and sea-ice 1889 processes in the Polar North Atlantic. Geological Society, London, Special Publications $1890 \quad 203,33-54$.

1891 Dowdeswell, J.A., Cofaigh, C.Ó, Pudsey, C.J., 2004. Thickness and extent of the subglacial till 1892 layer beneath an Antarctic palaeo-ice stream. Geology 32, 13-16.

1893 Dowdeswell, J.A., Ottesen, D., Rise, L., Craig, J., 2007. Identification and preservation of 1894 landforms diagnostic of past ice-sheet activity on continental shelves from three1895 dimensional seismic evidence. Geology 35, 359-362.

1896 Dowdeswell, J.A., Cofaigh, C.Ó., Noormets, R., Larter, R.D., Hillenbrand, C.D., Benetti, S., 1897 Evans, J. and Pudsey, C.J., 2008. A major trough-mouth fan on the continental margin of the 1898 Bellingshausen Sea, West Antarctica: The Belgica Fan. Marine Geology 252, 129-140.

1899 Dowdeswell, J. A., Ottesen, D., Evans, J., Cofaigh, C.Ó., Anderson, J. B., 2008. Submarine 1900 glacial landforms and rates of ice-stream collapse. Geology 36, 819-822. 
1902 Dowdeswell, J.A., Ottesen, D., Rise, L., 2010. Rates of sediment delivery from the

1903 Fennoscandian Ice Sheet through an ice age. Geology 38, 3-6.

1904 Dowdeswell, J.A., Hogan, K.A., Cofaigh, C.Ó., Fugelli, E.M.G., Evans, J., Noormets, R.,

1905 2014. Late Quaternary ice flow in a West Greenland fjord and cross-shelf trough system:

1906 submarine landforms from Rink Isbrae to Uummannaq shelf and slope. Quaternary Science

1907 Reviews 92, 292-309.

1908 Dühnforth, M., Anderson, R.S., Ward, D., Stock, G.M., 2010. Bedrock fracture control of 1909 glacial erosion processes and rates. Geology 38, 423-426.

1910 Dumont, M., Brun, E., Picard, G., Michou, M., Libois, Q., Petit, J-R., Geyer, M., Morin, S.,

1911 Josse, B., 2014. Contribution of light-absorbing impurities in snow to Greenland's

1912 darkening since 2009. Nature Geoscience 7, 509-512. doi:10.1038/ngeo2180

1913 Egholm, D. L., Pedersen, V. K., Knudsen, M. F., Larsen, N. K., 2012. Coupling the flow of

1914 ice, water, and sediment in a glacial landscape evolution model. Geomorphology 141, 47-

191566.

1916 Egholm, D. L., Nielsen, S. B., Pedersen, V. K., Lesemann, J.-E., 2009. Glacial effects limiting

1917 mountain height., Nature 460, 884-887. doi:10.1038/nature08263

1918 Eidvin, T., Jansen, E., Riis, F., 1993. Chronology of Tertiary fan deposits off the western

1919 Barents Sea - implications for the uplife and erosion history of the Barents shelf. Marine $1920 \quad$ Geology 112, 109-131.

1921 Eisen, O., Harrison, W.D., Raymond, C.F., 2001. The surges of Variegated Glacier, Alaska, 1922 USA, and their connection to climate and mass balance. Journal of Glaciology 47, 351-358.

1923 Elverhøi, A.,1984. Glacigenic and associated marine sediments in the Weddell Sea, fjords of 1924 Spitsbergen and the Barents Sea: a review. Marine Geology 57, 53-88. 
1925 Elverhøi, A., Andersen, E. S., Dokken, T., Hebbeln, D., Spielhagen, R., Svendsen, J. I.,

1926 Sorflaten, M., Rornes, A., Hald, M., Forsberg, C. F., 1995. The growth and decay of the

1927 Late Weichselian ice sheet in western Svalbard and adjacent areas based on provenance

1928 studies of marine sediments. Quaternary Research 44, 303-316

1929 Elverhøi, A., Dowdeswell, J.A., Funder, S., Mangerud, J., Stein, R., 1998a. Glacial and oceanic

1930 history of the Polar North Atlantic Margins: An overview. Quaternary Science Reviews 17,

$1931 \quad 1-10$.

1932 Elverhøi, A., Hooke, R. LeB. Solheim, A., 1998b. Late Cenozoic erosion and sediment yield

1933 from the Svalbard-Barents Sea region: implications for understanding erosion of glacierized

1934 basins. Quaternary Science Reviews 17, 209-241.

1935 Elverhøi, A., de Blasio, F.V., Butt, F.A., Issler, D., Harbitz, C., Engvik, L., Solheim, A., Marr,

1936 J., 2002. Submarine mass-wasting on glacially-influenced continental slopes: processes and

1937 dynamics. Geological Society, London, Special Publications 203,73-87.

1938 Engelhardt, H., Humphrey, N., Kamb, B., Fahnestock, M., 1990. Physical conditions at the

1939 base of a fast moving Antarctic ice stream. Science 248, 57-59.

1940 Enkelmann, E., Zeitler, P.K., Garver, J.I., Pavlis, T.L., Hooks, B.P., 2010. The

1941 Thermochronological record of tectonic and surface process interaction at the Yakutat-North

1942 American collision zone in Southeast Alaska. American Journal of Science 310, 231-260.

1943 Evans, J., Pudsey, C. J., 2002. Sedimentation associated with Antarctic Peninsula ice shelves:

1944 implications for palaeoenvironmental reconstructions of glacimarine sediments. Journal of

1945 the Geological Society 159, 233-237. 
1946 Evans, J., Dowdeswell, J.A., Grobe, H., Niessen, F., Stein, R., Hubberten, H.W., Whittington, 1947 R.J., 2002. Late Quaternary sedimentation in Kejser Franz Joseph Fjord and the continental 1948 margin of East Greenland. Geological Society, London, Special Publications 203, 149-179.

1949 Eyles, C.H., Eyles, N., Lagoe, M.B., 1991. The Yakataga Formation; A late Miocene to

1950 Pleistocene record of temperate glacial-marine sedimentation in the Gulf of Alaska. In: J.B.

1951 Anderson and G.M. Ashley (Eds.), Glacial Marine Sedimentation: Paleoclimatic

1952 Significance. Geological Society of America, Boulder, CO, 159-180.

1953 Eyles, N., Eyles, C. H. 1992. Glacial depositional systems. In: Walker, R.G. and James, M.P.

1954 (Eds.) Facies Models: Response to sea level change. Geological Association of Canada 731955100.

1956 Fairbanks, R. G., 1989. A 17,000-year glacio-eustatic sea level record: Influence of glacial 1957 melt- ing rates on the Younger Dryas event and deep ocean circulation. Nature 342, 637$1958 \quad 643$.

1959 Faleide, J.I., Solheim, A., Fiedler, A., Hjelstuen, B.O., Andersen, E.S. Vanneste, K., 1996. Late 1960 Cenozoic evolution of the western Barents Sea-Svalbard continental margin. Global and 1961 Planetary Change 12, 53-74.

1962 Fastook, J.L., Hughes, T.J., 2013. New perspectives on paleoglaciology. Quaternary Science 1963 Reviews 80, 169-194.

1964 Fernandez, R. A., Anderson, J. B., Wellner, J.S., Hallet, B., 2011. Timescale dependence of 1965 glacial erosion rates: a case study of Marinelli Glacier, Cordillera Darwin, southern 1966 Patagonia. Journal of Geophysical Research 116(F1), 1-18, doi:10.1029/2010JF001685.

1967 Fischer, M. P., Powell, R.D., 1998. A simple model for the influence of push-morainal banks 1968 on the calving and stability of glacial tidewater termini. J. Glaciol. 44, 31-41. 
1969 Flowerdew, M.J., Tyrrell, S., Peck, V.L., 2013. Inferring sites of subglacial erosion using the

$1970 \mathrm{~Pb}$ isotopic composition of ice-rafted feldspar: Examples from the Weddell Sea, Antarctica.

1971 Geology 41, 147-150. doi:10.1130/G33644.1

1972 Flowerdew, M.J., Tyrrell, S., Riley, T.R., Whitehouse, M.J., Mulvaney, R., Leat, P.T.,

1973 Marschall, H.R., 2012. Distinguishing East and West Antarctic sediment sources using the

$1974 \quad \mathrm{~Pb}$ isotope composition of detrital K-feldspar. Chemical Geology 292, 88-102.

1975 Forwick, M., Vorren, T. O., 2009. Late Weichselian and Holocene sedimentary environments

1976 and ice rafting in Isfjorden, Spitsbergen. Palaeogeography, Palaeoclimatology,

1977 Palaeoecology 280, 258-274.

1978 Fortuin, J.P.F., Oerlemans, J., 1990. Parameterization of the annual surface temperature and 1979 mass balance of Antarctica. Annals of Glaciology 14, 78-84.

1980 Fuchs, M., Owen, L.A., 2008. Luminescence dating of glacial and associated sediments:

1981 review, recommendations and future directions. Boreas 37, 636-659.

1982 Funder, S., Hjort, C., Landvik, J.Y., Nam, S.I., Reeh, N., Stein, R., 1998. History of a stable ice 1983 margin East Greenland during the Middle and Upper Pleistocene. Quaternary Science $1984 \quad$ Reviews 17, 77-123.

1985 Gales, J.A., Larter, R.D., Mitchell, N.C., Dowdeswell, J.A., 2013. Geomorphic signature of 1986 Antarctic submarine gullies: Implications for continental slope processes. Marine Geology $1987 \quad 337,112-124$.

1988 Garcia, M., Dowdeswell, J.A., Ercilla, G., Jakobsson, M., 2012. Recent glacially influenced 1989 sedimentary processes on the East Greenland continental slope and deep Greenland Basin. 1990 Quaternary Science Reviews 49, 64-81. 
1991 Garcia, M., Ercilla, G., Alonso, B., Casas, D., Dowdeswell, J.A., 2011. Sediment lithofacies, 1992 processes and sedimentary models in the Central Bransfield Basin, Antarctic Peninsula, 1993 since the Last Glacial Maximum. Marine Geology 290, 1-16.

1994 Gilbert, R., Chong, Å., Dunbar, R.B., Domack, E.W., 2003. Sediment Trap Records of 1995 Glacimarine Sedimentation at Müller Ice Shelf, Lallemand Fjord, Antarctic Peninsula. Arc. 1996 Antarc. Alp. Res. 35, 24-33.

1997 Gilbert, R., Nielsen, N., Moller, H., Desloges, J.R. Rasch, M., 2002. Glacimarine 1998 sedimentation in Kangerdluk (Disko Fjord), West Greenland, in response to a surging 1999 glacier. Marine Geology 191, 1-18.

2000 Gilbert, R., Nielsen, N., Desloges, J.R., Rasch, M., 1998. Contrasting glacimarine sedimentary 2001 environments of two arctic fiords on Disko, West Greenland. Marine Geology 147, 63-83. 2002 Goehring BM, Schaefer JM, Schluechter C., Lifton, N. A., Finkel, R. C., Jull, A. T., Akcar, N., 2003 Alley, R. B., 2011. The Rhone glacier was smaller than today for most of the Holocene. 2004 Geology 39, 679-682.

2005 Goff, J.A., Lawson, D.E., Willems, B.A., Davis, M., Gulick, S.P.S., 2012. Morainal bank 2006 progradation and sediment accumulation in Disenchantment Bay, Alaska: Response to 2007 advancing Hubbard Glacier. Journal of Geophysical Research-Earth Surface 117, F02031, 2008 doi:10.1029/2011JF002312.

2009 Golledge, N.R., Levy, R.H., McKay, R.M., Fogwill, C.J., White, D.A., Graham, A.G.C., 2010 Smith, J.A., Hillenbrand, C.-D., Licht, K.J., Denton, G.H., Ackert Jr., R.P., Mass, S.M., 2011 Hall, B.L., 2013. Glaciology and geological signature of the Last Glacial Maximum 2012 Antarctic Ice Sheet. Quat. Sci. Rev. 78, 225-247. 
2013 Graham, A.G.C., Larter, R.D., Gohl, K., Dowdeswell, J.A., Hillenbrand, C.D., Smith, J.A., 2014 Evans, J., Kuhn, G., Deen, T., 2010. Flow and retreat of the Late Quaternary Pine 2015 Island-Thwaites palaeo-ice stream, West Antarctica. Journal of Geophysical Research: Earth $2016 \quad$ Surface (2003-2012) 115, no. F3.

2017 Granger, D. E., Lifton, N. A., Willenbring, J. K., 2013. A cosmic trip: 25 years of cosmogenic 2018 nuclides in geology. Geological Society of America Bulletin 125, 1379-1402.

2019 Griffith, T.W., Anderson, J.B., 1989. Climatic control of sedimentation in bays and fjords of 2020 the northern Antarctic Peninsula. Marine Geology 85, 181-204.

2021 Gurnell, A., Hannah, D., Lawler, D., 1996. Suspended sediment yields from glacier basins. In 2022 Erosion and Sediment Yield: Global and Regional Perspectives, IASH Publication 236, $97-$ 2023104.

2024 Hagen, J. O., Liestøl, O., Roland, E., Jørgensen, T., 1993. Glacier atlas of Svalbard and Jan 2025 Mayen. Meddelelser;129, Norsk Polarinstitutt.

2026 Hald, M., Dahlgren, T., Olsen, T.E., Lebesbye, E., 2001. Late Holocene palaeoceanography in 2027 Van Mijenfjorden, Svalbard. Polar Research 20, 23-35.

2028 Hall, B.L., 2009. Holocene glacial history of Antarctica and the sub-Antarctic islands. 2029 Quaternary Science Reviews 28, 2213-2230.

2030 Hallet, B. 1979. A theoretical model of glacial abrasion. Journal of Glaciology 23, 29-50.

2031 Hallet, B., 1996. Glacial quarrying: a simple theoretical model. Annals of Glaciology 22, 1-8.

2032 Hallet, B., Hunter, L., Bogen, J., 1996. Rates of erosion and sediment evacuation by glaciers: A 2033 review of field data and their implications. Global and Planetary Change 12, 213-235, 2034 doi:10.1016/0921-8181(95)00021-6. 
2035 Hambrey, M.J., Glasser, N.F., 2012. Discriminating glacier thermal and dynamic regimes in 2036 the sedimentary record. Sedimentary Geology 251-252, 1-33.

2037 Hanson, M.A., Lian, O.B., Clague, J.J., 2012. The sequence and timing of large late

2038 Pleistocene floods from glacial Lake Missoula. Quaternary Science Reviews 31, 67-81.

2039 Harbor, J., 1992. Numerical modeling of the deveopment of U-shaped valleys by glacial 2040 erosion. Geol. Soc. Am. Bull. 104,1364-1375.

2041 Harbor, J. M., Hallet, B., Raymond, C. F., 1988. A numerical model of landform development 2042 by glacial erosion. Nature 333, $347-349$.

2043 Harden, S. L., DeMaster, D. J., Nittrouer, C. A., 1992. Developing sediment geochronologies 2044 for high-latitude continental shelf deposits: a radiochemical approach. Marine Geology 103, $2045 \quad 69-97$.

2046 Harris, P.T., Domack., E., Manley, P.L., Gilbert, R., Leventer, A., 1999. Andvord drift: a new 2047 type of inner shelf, glacial marine deposystem from the Antarctic Peninsula. Geology 27, $2048 \quad 683-686$.

2049 Harrison, W. D., Post, A. S., 2003. How much do we really know about glacier surging?. $2050 \quad$ Annals of Glaciology 36, 1-6.

2051 Harrison, W. D., Elsberg, D. H., Echelmeyer, K. A., Krimmel, R. M., 2001. On the 2052 characterization of glacier response by a single time-scale. Journal of Glaciology 47, 6592053664.

2054 Headley, R., Hallet, B., Roe, G., Waddington, E.D., Rignot, E., 2012. Spatial distribution of 2055 glacial erosion rates in the St. Elias range, Alaska, inferred from a realistic model of glacier 2056 dynamics. Journal of Geophysical Research-Earth Surface 117: F03027, 2057 doi:10.1029/2011JF002291. 
2058 Headley, R.M., Enkelmann, E., Hallet, B., 2013. Examination of the interplay between glacial 2059 processes and exhumation in the Saint Elias Mountains, Alaska. Geosphere 9, 229-241.

2060 Hebbeln, D., Henrich, R., Baumann, K.H., 1998. Paleoceanography of the last

2061 interglacial/glacial cycle in the Polar North Atlantic. Quaternary Science Reviews 17, 1252062153.

2063 Hemming, S.R., 2004. Heinrich events: Massive late pleistocene detritus layers of the North 2064 Atlantic and their global climate imprint. Reviews of Geophysics 42, RG1005, 2065 doi:10.1029/2003RG000128.

2066 Hendy, I. L., Cosma, T., 2008. Vulnerability of the Cordilleran Ice Sheet to iceberg calving 2067 during Late Quaternary rapid climate change events. Paleoceanography 23, PA2101, 2068 doi:10.1029/2008PA001606.

2069 Henriksen, M., Alexanderson, H., Landvik, J. Y., Linge, H., Peterson, G., 2014. Dynamics and 2070 retreat of the Late Weichselian Kongsfjorden ice stream, NW Svalbard. Quaternary Science 2071 Reviews 92, 235-245.

2072 Herman, F., Braun, J., 2008. Evolution of the glacial landscape of the Southern Alps of New 2073 Zealand: Insights from a glacial erosion model. Journal of Geophysical Research: Earth $2074 \quad$ Surface 113, F02009, doi:10.1029/2007JF000807.

2075 Herman, F., Beaud, F., Champagnac, J.-D., Lemieux, J.-M., Sternai, P., 2011. Glacial 2076 hydrology and erosion patterns: a mechanism for carving glacial valleys. Earth and 2077 Planetary Science Letters 310, 498-508.

2078 Herman, F., Seward, D., Valla, P. G., Carter, A., Kohn, B., Willett, S. D., Ehlers, T. A., 2013. 2079 Worldwide acceleration of mountain erosion under a cooling climate. Nature 504, 423-426. 
2080

2081

2082

2083

2084

2085

2086

2087

2088

2089

2090

2091

2092

2093

2094

2095

2096

2097

2098

2099

2100

2101

2102

Heyman, J., Stroeven, A. P., Harbor, J. M., Caffee, M. W., 2011. Too young or too old: evaluating cosmogenic exposure dating based on an analysis of compiled boulder exposure ages. Earth and Planetary Science Letters 302, 71-80.

Hill, P.S., Syvitski, J.P., Cowan, E.A., Powell, R.D., 1998. In situ observations of floc settling velocities in Glacier Bay, Alaska. Marine Geology 145, 85-94.

Hillenbrand, C. D., Baesler, A., Grobe, H., 2005. The sedimentary record of the last glaciation in the western Bellingshausen Sea (West Antarctica): implications for the interpretation of diamictons in a polar-marine setting. Marine Geology 216, 191-204.

Hillenbrand, C.D., Larter, R.D., Dowdeswell, J.A., Ehrmann, W., Cofaigh, C.Ó., Benetti, S., Graham, A.G.C., Grobe, H., 2010a. The sedimentary legacy of a palaeo-ice stream on the shelf of the southern Bellingshausen Sea: Clues to West Antarctic glacial history during the Late Quaternary. Quaternary Science Reviews 29, 2741-2763.

Hillenbrand, C.D., Smith, J.A., Kuhn, G., Esper, O., Gersonde, R., Larter, R.D., Maher, B., Moreton, S.G., Shimmield, T.M., Korte, M., 2010b. Age assignment of a diatomaceous ooze deposited in the western Amundsen Sea Embayment after the Last Glacial Maximum. Journal of Quaternary Science 25, 280-295.

Hillenbrand, C.D., Bentley, M.J., Stolldorf, T.D., Hein, A.S., Kuhn, G., Graham, A.G.C., Fogwill, C.J., Kristoffersen, Y., Smith, J.A., Anderson, J.B., Larter, R.D., Melles, M., Hodgson, D.A., Mulvaney, R., Sugden, D.E., 2014. Reconstruction of changes in the Weddell Sea sector of the Antarctic Ice Sheet since the Last Glacial Maximum. Quaternary Science Reviews 100, 111-136.

Hodgson, D.A., Graham, A.G.C., Roberts, S.J., Bentley, M.J., Cofaigh, C.Ó., Verleyen, E., Vyverman, W., Jomelli, V., Favier, V., Brunstein, D., Verfaillie, D., Colhoun, E.A., 
Saunders, K.M., Selkirk, P.M., Mackintosh, A., Hedding, D.W., Nel, W., Hall, K., McGlone, M.S., Van der Putten, N., Dickens, W.A., Smith, J.A., 2014. Terrestrial and submarine evidence for the extent and timing of the Last Glacial Maximum and the onset of deglaciation on the maritime-Antarctic and sub-Antarctic islands. Quaternary Science Reviews 100, 137-158.

Hogan, K.A., Dowdeswell, J.A., Noormets, R., Evans, J., Cofaigh, C.Ó., 2010. Evidence for full-glacial flow and retreat of the Late Weichselian Ice Sheet from the waters around Kong Karls Land, eastern Svalbard. Quaternary Science Reviews 29(25-26): 3563-3582.

Hogan, K. A., Dix, J. K., Lloyd, J. M., Long, A. J., Cotterill, C. J., 2011. Seismic stratigraphy records the deglacial history of Jakobshavn Isbrae, West Greenland. Journal of Quaternary Science 26, 757-766.

Hogan, K.A., Dowdeswell, J.A., Cofaigh, C.Ó., 2012. Glacimarine sedimentary processes and

2117 Hooke, R. LeB., Elverhøi, E., 1996. Sediment flux from a fjord during glacial periods, 2118 Isfjorden, Spitsbergen. Global and Planetary Change 12, 237-249.

2119 Hormes, A., Gjermundsen, E.F., Rasmussen, T.L., 2013. From mountain top to the deep sea 2120 Deglaciation in 4D of the northwestern Barents Sea ice sheet. Quaternary Science Reviews, $2121 \quad 7578-99$.

2122 Hughes, T.J., 1992. Theoretical calving rates from glaciers along ice walls grounded in water 2123 of variable depths. Journal of Glaciology 38, 282-294.

2124 Humphrey, N., Raymond, C.F., 1994. Hydrology, erosion and sediment production in a surging 2125 glacier: Variegated Glacier, Alaska, 1982-83. Journal of Glaciology 40, 539-552. 
2126 Humphrey, N.F., Kamb, B., Fahnestock, M. A., Engelhardt, H., 1993. Characteristics of the

2127 Bed of the Lower Columbia Glacier, Alaska. Journal of Geophysical Research 98(B1):

$2128 \quad 837-846$.

2129 Hunter, L.E., Powell, R.D. and Lawson, D.E., 1996a. Flux of debris transported by ice at three 2130 Alaskan glaciers. Journal of Glaciology 42, 123-135.

2131 Hunter, L.E., Powell, R.D. and Lawson, D.E., 1996b. Morainal-bank sediment budgets and 2132 their influence on the stability of tidewater termini of valley glaciers entering Glacier Bay, 2133 Alaska, U.S.A. Annals of Glaciology 22, 211-216.

2134 Huybers, K., Roe, G.H., 2009. Spatial patterns of glaciers in response to spatial patterns in 2135 regional climate. Journal of Climate 22, 4606-4620.

2136 Iken, A., Bindschadler, R., 1986. Combined measurements of subglacial water pressure and 2137 surface velocity of Findelengletscher, Switzerland: conclusions about drainage system and 2138 sliding mechanism. Journal of Glaciology 32, 101-119.

2139 Imbrie, J., Hays, J.D., Martinson, D.G., McIntyre, A., Mix, A.C., Morley, J.J., Pisias, N.G., 2140 Prell, W.L., Shackleton, N.J., 1984. The orbital theory of Pleistocene climate: Support from 2141 a revised chronology of the marine delta180 record. In: Milankovitch and climate:

$2142 \quad$ Understanding the response to astronomical forcing, vol. 1, p. 269.

2143 Ingólfsson, Ó., Landvik, J.Y., 2013. The Svalbard-Barents Sea ice-sheet - Historical, current 2144 and future perspectives. Quaternary Science Reviews 64, 33-60.

2145 Iverson, N.R., 1991. Potential effects of subglacial water-pressure fluctuations on quarrying. J. $2146 \quad$ Glaciology 37, 27-36.

2147 Iverson, N. R., 2012. A theory of glacial quarrying for landscape evolution models. Geology $2148 \quad$ 40, 679-682. doi:10.1130/G33079.1. 
2149 Jaeger, J.M., 2002. Developing high-resolution chronologies in glacimarine sediments:

2150 examples from southeastern Alaska. Geological Society, London, Special Publications 203, $2151 \quad 195-214$.

2152 Jaeger, J.M. and Nittrouer, C.A., 1999a. Marine record of surge-induced outburst floods from 2153 the Bering Glacier, Alaska. Geology 27, 847-850.

2154 Jaeger, J.M. and Nittrouer, C.A., 1999b. Sediment deposition in an Alaskan fjord: Controls on 2155 the formation and preservation of sedimentary structures in Icy Bay. Journal of Sedimentary $2156 \quad$ Research 69, 1011-1026.

2157 Jaeger, J.M. and Nittrouer, C.A., 2006. A quantitative examination of modern sedimentary

2158 lithofacies formation on the glacially influenced Gulf of Alaska continental shelf.

2159 Continental Shelf Research 26, 2178-2204.

2160 Jaeger, J.M. and Kramer, B., 2014. A continental shelf sedimentary record of Little Ice Age to 2161 modern glacial dynamics: Bering Glacier, Alaska. Continental Shelf Research 86, 141-156.

2162 Jaeger, J.M., Nittrouer, C.A., Scott, N.D., Milliman, J.D. (1998). Sediment accumulation along 2163 a glacially impacted mountainous coastline: north-east Gulf of Alaska. Basin Res. 10, 155$2164 \quad 173$.

2165 Jakobsson, M., et al. 2012. The International Bathymetric Chart of the Arctic Ocean (IBCAO) 2166 Version 3.0, Geophys. Res. Lett. 39, L12609, doi:10.1029/2012GL052219.

2167 Jakobsson, M., Andreassen, K., Bjarnadottir, L.R., Dove, D., Dowdeswell, J.A., England, J.H., 2168 Funder, S., Hogan, K., Ingoolfsson, O., Jennings, A., Larsen, N.K., Kirchner, N., Landvik, 2169 J.Y., Mayer, L., Mikkelsen, N., Moller, P., Niessen, F., Nilsson, J., O'Regan, M., Polyak, L., 2170 Norgaard-Pedersen, N. and Stein, R., 2014. Arctic Ocean glacial history. Quaternary $2171 \quad$ Science Reviews 92, 40-67. 
2172 Jennings, A.E., Weiner, N.J., 1996. Environmental change on eastern Greenland during the last 21731300 years: evidence from foraminifera and lithofacies in Nansen Fjord, $68^{\circ} \mathrm{N}$. The

$2174 \quad$ Holocene 6, 179-191.

2175 Jerolmack, D. J. and Sadler, P., 2007. Transience and persistence in the depositional record of 2176 continental margins. J. Geophys. Res 112, F03S13

2177 Jiskoot, H., Murray, T., Boyle, P., 2000. Controls on the distribution of surge-type glaciers in 2178 Svalbard. Journal of Glaciology 46, 412-422.

2179 Joughin, I., Alley, R.B., Holland, D.M., 2012. Ice-sheet response to oceanic forcing. Science $2180 \quad 338,1172-1176$, doi:10.1126/science.1226481.

2181 Joughin, I., Howat, I.M., Alley, R.B., Ekstrom, G., Fahnestock, M., Moon, T., Nettles, M., 2182 Truffer, M., Tsai, V.C., 2008. Ice-front variation and tidewater behavior on Helheim and 2183 Kangerdlugssuaq Glaciers, Greenland. J. Geophy. Res. 113(F1), 1-11, 2184 doi:10.1029/2007JF000837.

2185 Kamb, B., Raymond, C.F., Harrison, W.D., Engelhardt, H., Echelmeyer, K.A., Humphrey, N., 2186 Brugman, M.M., Pfeffer, T., 1985. Glacier surge mechanism: 1982-1983 surge of $2187 \quad$ Variegated Glacier, Alaska, Science 227, 469-479.

2188 Kawamura, K., Aoki, S., Nakazawa, T., Matsushima, H., Ishidoya, S., Sugawara, S., Lisiecki, 2189 L., Raymo, M.E., Severinghaus, J.P., 2008. Accurate chronology of Antarctic climate and 2190 greenhouse gas changes over the past $470 \mathrm{ky}$. Geochimica Et Cosmochimica Acta 72, $2191 \quad$ A454-A454.

2192 Kempf, P., Forwick, M., Laberg, J.S., Vorren, T.O., 2013. Late Weichselian and Holocene 2193 sedimentary palaeoenvironment and glacial activity in the high-arctic van Keulenfjorden, $2194 \quad$ Spitsbergen. Holocene 23, 1607-1618. 
2195 Kessler, M. A., Anderson, R. S., Briner, J. P., 2008. Fjord insertion into continental margins

2196 driven by topographic steering of ice. Nature Geoscience 1, 365-369.

2197 Kilfeather, A. A., Cofaigh, C.Ó., Lloyd, J. M., Dowdeswell, J. A., Xu, S., Moreton, S. G.,

2198 2011. Ice-stream retreat and ice-shelf history in Marguerite Trough, Antarctic Peninsula:

2199 Sedimentological and foraminiferal signatures. Geological Society of America Bulletin 123, $2200 \quad 997-1015$.

2201 King, E.L., Haflidason, H., Sejrup, H.P. Lovlie, R., 1998. Glacigenic debris flows on the North 2202 Sea Trough Mouth Fan during ice stream maxima. Marine Geology 152, 217-246.

2203 Kirchner, N., Greve, R., Stroeven, A.P., Heyman, J., 2011a. Paleoglaciological reconstructions 2204 for the Tibetan Plateau during the last glacial cycle: evaluating numerical ice sheet 2205 simulations driven by GCM-ensembles. Quaternary Science Reviews 30, 248-267.

2206 Kirchner, N., Hutter, K., Jakobsson, M., Gyllencreutz, R., 2011b. Capabilities and limitations 2207 of numerical ice sheet models: a discussion for Earth-scientists and modelers. Quaternary $2208 \quad$ Science Reviews 30, 3691-3704.

2209 Kirshner, A.E., Anderson, J.B., Jakobsson, M., O'Regan, M., Majewski, W. and Nitsche, F.O., 2210 2012. Post-LGM deglaciation in Pine Island Bay, West Antarctica. Quaternary Science $2211 \quad$ Reviews 38, 11-26.

2212 Knies, J., Matthiessen, J., Vogt, C., Laberg, J.S., Hjelstuen, B.O., Smelror, M., Larsen, E., 2213 Andreassen, K., Eidvin, T. and Vorren, T.O., 2009. The Plio-Pleistocene glaciation of the 2214 Barents Sea-Svalbard region: a new model based on revised chronostratigraphy. Quaternary $2215 \quad$ Science Reviews 28, 812-829.

2216 Koppes, M., Montgomery, D., 2009. The relative efficacy of fluvial and glacial erosion over 2217 modern to orogenic timescales. Nature Geoscience 2, 644-647. 
2218 Koppes, M., Hallet, B., 2006. Erosion rates during rapid deglaciation in Icy Bay, Alaska.

2219 Journal of Geophysical Research: Earth Surface 111(F2).

2220 Koppes, M.N., Hallet, B., 2002. Influence of rapid glacial retreat on the rate of erosion by 2221 tidewater glaciers. Geology 30, 47-50.

2222 Koppes, M., Hallet, B., Anderson, J., 2009. Synchronous acceleration of ice loss and glacier 2223 erosion, Marinelli Glacier, Tierra del Fuego. Journal of Glaciology 55, 207-220.

2224 doi:10.3189/002214309788608796.

2225 Koppes, M., Sylwester, R., Rivera, A., Hallet, B., 2010. Variations in sediment yield over the 2226 advance and retreat of a calving glacier, Laguna San Rafael, North Patagonian Icefield, 2227 Quaternary Research 73, 84-95, doi:10.1016/j.yqres.2009.07.006.

2228 Koppes, M., Hallet, B., Rignot, E., Mouginot, J., Wellner, J.S., Boldt, K., 2015. Observed 2229 latitudinal variations in erosion as a function of glacier dynamics. Nature (in press).

2230 Krissek, L.A., 1995. Late Cenozoic ice-rafting records from Leg 145 sites in the North Pacific:

2231 late Miocene onset, late Pliocene intensification, and Pliocene-Pleistocene events. In Rea,

2232 D.K., Basov, I.A., Scholl, D.W., and Allan, J.F. (Eds.), Proc. ODP, Sci. Results, 145:

2233 College Station, TX (Ocean Drilling Program), 179-194.

$2234 \quad$ doi:10.2973/odp.proc.sr.145.118.1995

2235 Kristensen, L., Benn, D.I., Hormes, A., et al., 2009. Mud aprons in front of Svalbard surge 2236 moraines: Evidence of subglacial deforming layers or proglacial glaciotectonics? 2237 Geomorphology 111, 206-221.

2238 Kroon, D., Shimmield, G., Austin, W.E.N., Derrick, S., Knutz, P. Shimmield, T., 2000.

2239 Century- to millennial-scale sedimentological-geochemical records of glacial-Holocene 
sediment variations from the Barra Fan (NE Atlantic). Journal of the Geological Society 157: 643-653.

2242 Kuijpers, A., Dalhoff, F., Brandt, M.P., Hümbs, P., Schott, T., Zotova, A., 2007. Giant iceberg 2243 plow marks at more than $1 \mathrm{~km}$ water depth offshore West Greenland. Mar. Geol. 246, 60$2244 \quad 64$.

2245 Laberg, J.S., Vorren, T.O., 1996. The Middle and Late Pleistocence evolution and the Bear 2246 Island Trough Mouth Fan. Global and Planetary Change 12, 309-330.

2247 Laberg, J.S., Andreassen, K., Knies, J., Vorren, T.O. and Winsborrow, M., 2010. Late

2248 Pliocene-Pleistocene development of the Barents Sea Ice Sheet. Geology 38, 107-110.

2249 Laberg, J.S., Eilertsen, R.S., Vorren, T.O., 2009. The palaeo-ice stream in Vestfjorden, north $2250 \quad$ Norway, over the last 35 k.y.: glacial erosion and sediment yield. GSA Bulletin 121, 4342251447.

2252 Landvik, J.Y., Alexanderson, H., Henriksen, M., Ingolfsson, O., 2014. Landscape imprints of 2253 changing glacial regimes during ice-sheet build-up and decay: a conceptual model from 2254 Svalbard. Quaternary Science Reviews 92, 258-268.

2255 Landvik, J.Y., Bondevik, S., Elverh^i, A., Fjeldskaar, W., Mangerud, J., Siegert, M.J., 2256 Salvigsen, O., Svendsen, J.-I., Vorren, T.O., 1998. Last glacial maximum of Svalbard and 2257 the Barents Sea area: ice sheet extent and configuration. Quaternary Science Reviews 17, $2258 \quad 43-75$.

2259 Landvik, J.Y., Ingolfsson, O., Mienert, J., Lehman, S.J., Solheim, A., Elverhoi, A., Ottesen, D., 2260 2005. Rethinking Late Weichselian ice-sheet dynamics in coastal NW Svalbard. Boreas 34, $2261 \quad 7-24$. 
Larsen, H.C., Saunders, A.D., Clift, P.D., Beget, J., Wei, W., Spezzaferri, S., Ali, J., Cambray, H., Demant, A., Fitton, G., Fram, M.S., Fukuma, K., Gieskes, J., Holmes, M.A., Hunt, J., Lacasse, C., Larsen, L.M., Lykkeanderson, H., Meltser, A., Morrison, M.L., Nemoto, N., Okay, N., Saito, S., Sinton, C., Stax, R., Vallier, T.L., Vandamme, D., Werner, R., Cliff, P.D., 1994. 7-Million years of glaciation in Greenland. Science 264, 952-955.

Larter, R.D., Anderson, J.B., Graham, A.G.C., Gohl, K., Hillenbrand, C.D., Jakobsson, M., Johnson, J.S., Kuhn, G., Nitsche, F.O., Smith, J.A., Witus, A.E., Bentley, M.J., Dowdeswell, J.A., Ehrmann, W., Klages, J.P., Lindow, J., Cofaigh, C.Ó., Spiegel, C., 2014.

Reconstruction of changes in the Amundsen Sea and Bellingshausen Sea sector of the West Antarctic Ice Sheet since the Last Glacial Maximum. Quaternary Science Reviews 100, 55-

2273 Lauritzen, S.-E., 1991. Uranium series dating of speleothems: A glacial chronology for $2274 \quad$ Nordland, Norway, for the last 600 ka. Striae 34, 127-133.

2275 Lawson, D. E., 1993. Glaciohydrologic and glaciohydraulic effects on runoff and sediment 2276 yield in glacierized basins, Monogr. 93-2, Cold Reg. Res. and Eng. Lab., U.S. Army Corps 2277 of Eng., Hanover, N. H., USA. 108 pp.

2278 Lekens, W.A.H., Sejrup, H.P., Haflidason, H., Petersen, G.O., Hjelstuen, B., Knorr, G., 2005. 2279 Laminated sediments preceding heinrich event 1 in the Northern North Sea and Southern $2280 \quad$ Norwegian Sea: Origin, processes and regional linkage. Marine Geology 216, 27-50.

2281 Leventer A, Dunbar R, DeMaster D. 1993. Diatom evidence for Late Holocene climatic events 2282 in Granite Harbor, Antarctica. Paleoceanography 8, 373-386. 
2283 Leventer, A., Domack, E., Dunbar, R., Pike, J., Stickley, C., Maddison, E., Brachfeld, S., 2284 Manley, P., McClennen, C., 2006. Marine sediment record from the East Antarctic margin 2285 reveals dynamics of ice sheet recession. GSA Today 16, 4. doi:10.1130/GSAT01612A.1

2286 Licht, K.J., Andrews, J.T., 2002. The C-14 record of Late Pleistocene ice advance and retreat in 2287 the central Ross Sea, Antarctica. Arctic Antarctic and Alpine Research 34, 324-333.

2288 Licht, K.J., Jennings, A.E., Andrews, J.T., Williams, K.M., 1996. Chronology of late 2289 Wisconsin ice retreat from the western Ross Sea, Antarctica. Geology 24, 223-226.

2290 Licht, K.J., Dunbar, N.W., Andrews, J.T., Jennings, A.E., 1999. Distinguishing subglacial till 2291 and glacial marine diamictons in the western Ross Sea, Antarctica: Implications for a last 2292 glacial maximum grounding line. Geological Society of America Bulletin 111, 91-103. 2293 Lindow, J., Castex, M., Wittmann, H., Johnson, J.S., Lisker, F., Gohl, K., Spiegel, C., 2014. 2294 Glacial retreat in the Amundsen Sea sector, West Antarctica - first cosmogenic evidence 2295 from central Pine Island Bay and the Kohler Range. Quaternary Science Reviews 98, 1662296173.

2297 Lingle, C.S. and Fatland, D.R., 2003. Does englacial water storage drive temperate glacier 2298 surges? Annals of Glaciology 36, 14-20.

2299 Lisiecki, L.E., Raymo, M.E., 2007. Plio-Pleistocene climate evolution: trends and transitions in 2300 glacial cycle dynamics. Quaternary Science Reviews 26, 56-69.

2301 Livingstone, S.J., Cofaigh, C.Ó., Stokes, C.R., Hillenbrand, C.-D., Vieli, A., Jamieson, S.S.R., 2302 2012. Antarctic palaeo-ice streams. Earth-Science Reviews 111, 90-128.

2303 Lloyd, J. M., 2006. Late Holocene environmental change in Disko Bugt, west Greenland: 2304 interaction between climate, ocean circulation and Jakobshavn Isbrae. Boreas 35, 35-49. 
Lloyd, J. M., Park, L. A., Kuijpers, A., Moros, M., 2005. Early Holocene palaeoceanography and deglacial chronology of Disko Bugt, west Greenland. Quaternary Science Reviews 24, 1741-1755.

2309 Lourens, L.J., Becker, J., Bintanja, R., Hilgen, F.J., Tuenter, E., van de Wal, R.S.W., Ziegler, 2310 M., 2010. Linear and non-linear response of late Neogene glacial cycles to obliquity forcing 2311 and implications for the Milankovitch theory. Quaternary Science Reviews 29, 352-365.

2312 Lowe, A.L., Anderson, J.B., 2002. Reconstruction of the West Antarctic Ice Sheet in Pine 2313 Island Bay during the last glacial maximum and its subsequent retreat history. Quaternary $2314 \quad$ Science Reviews 21, 1879-1897.

2315 Lyell, C., 1840. Memoir on the geological evidence of the former existence of glaciers in 2316 Forfarshire. Proceedings of the Geological Society of London 3, 337-345.

2317 MacGregor, K.R., Anderson, R.S., Waddington, E.D., 2009. Numerical modeling of glacial 2318 erosion and headwall processes in alpine valleys. Geomorphology 103, 189-204 2319 Mackiewicz, N.E., Powell, R.D., Carlson, P.R., Molnia, B.F., 1984. Interlaminated ice2320 proximal glacimarine sediments in Muir Inlet, Alaska. Marine Geology 57, 113-147. 2321 Mackintosh, A.N., Verleyen, E., O'Brien, P.E., White, D.A., Jones, R.S., McKay, R., Dunbar, 2322 R., Gore, D.B., Fink, D., Post, A.L., Miura, H., Leventer, A., Goodwin, I., Hodgson, D.A., 2323 Lilly, K., Crosta, X., Golledge, N.R., Wagner, B., Berg, S., van Ommen, T., Zwartz, D., 2324 Roberts, S.J., Vyverman, W., Masse, G., 2014. Retreat history of the East Antarctic Ice 2325 Sheet since the Last Glacial Maximum. Quaternary Science Reviews 100, 10-30.

2326 Maddison, E., Pike, J., Leventer, A., Domack, E., 2005. Diatom rich sediments from Palmer 2327 Deep, Antarctica: Seasonal and sub-seasonal record through the last deglaciation. Journal of 2328 Quaternary Science 20, 435-446, doi: 10.1002/jqs.947. 
Maddison, E., Pike, J., Leventer, A., Dunbar, R., Brachfeld, S., Domack, E., Manley, P.,

2330 McClennen, C., 2006. Post-glacial seasonal diatom record of the Mertz Glacial Polynya,

2331 East Antarctica. Marine Micropaleontology 60, 66-88,

2332 doi:10.1016/j.marmicro.2006.03.001.

2333 Mangerud, J., Dokken, T., Hebbeln, D., Heggen, B., Ingolfsson, O., Landvik, J.Y., Mejdahl, 2334 V., Svendsen, J.I. and Vorren, T.O., 1998. Fluctuations of the Svalbard Barents Sea Ice 2335 Sheet during the last 150000 years. Quaternary Science Reviews 17, 11-42.

2336 Marcott, S.A., Clark, P.U., Padman, L., Klinkhammer, G.P., Springer, S.R., Liu, Z., Otto2337 Bliesner, B.L., Carlson, A.E., Ungerer, A., Padman, J., He, F., Cheng, J., Schmittner, A., 2338 2011. Ice-shelf collapse from subsurface warming as a trigger for Heinrich events.

2339 Proceedings of the National Academy of Sciences of the United States of America 108, $2340 \quad 13415-13419$.

2341 Marzeion, B., Cogley, J.G., Richter, K., Parkes, D., 2014. Attribution of global glacier mass 2342 loss to anthropogenic and natural causes. Science 345, 919-921.

2343 McClintic, M. A., D. J. DeMaster, C. J. Thomas, Smith, C. R., 2008. Testing the

2344 FOODBANCS hypothesis: Seasonal variations in near-bottom particle flux, bioturbation 2345 intensity, and deposit feeding based on ${ }^{234}$ Th measurements, Deep Sea Res. Part II: Topical 2346 Studies in Oceanography 55, 2425-2437, doi:10.1016/j.dsr2.2008.06.003.

2347 McKay, R., Browne, G., Carter, L., Cowan, E., Dunbar, G., Krissek, L., Naish, T., Powell, R., 2348 Reed, J., Talarico, F., Wilch, T., 2009. The stratigraphic signature of the late Cenozoic 2349 Antarctic Ice Sheets in the Ross Embayment. Geological Society of America Bulletin 121, $2350 \quad 1537-1561$. 
Meier, M.F., Post, A., 1987. Fast Tidewater Glaciers. Journal Geophysical Research-Solid $2352 \quad$ Earth and Planets 92(B9), 9051-9058.

2353 Menounos, B., Osborn, G., Clague, J.J., Luckman, B.H., 2009. Latest Pleistocene and

$2354 \quad$ Holocene glacier fluctuations in western Canada. Quaternary Science Reviews 28, 204923552074.

2356 Merrand, Y., Hallet, B., 1996. Water and Sediment Flux During the 1993-94 Bering Glacier 2357 Surge, Alaska, USA. Annals of Glaciology 22, 233-240.

2358 Miller, G.H., Wolfe, A.P., Steig, E.J., Sauer, P.E., Kaplan, M.R., Briner, J.P., 2002. The 2359 Goldilocks dilemma: big ice, little ice, or "just-right" ice in the Eastern Canadian Arctic. 2360 Quaternary Science Reviews 21, 33-48.

2361 Milliken, K.T., Anderson, J.B., Wellner, J.S., Bohaty, S.M., Manley, P.L. 2009. High2362 resolution Holocene climate record from Maxwell Bay, South Shetland Islands, Antarctica, 2363 Geological Society of America Bulletin 121, 1711-1725, doi:10.1130/B26478.1.

2364 Milliman, J.D., Syvitski, J.P.M., 1992. Geomorphic/tectonic control of sediment discharge to 2365 the ocean: The importance of small mountainous rivers. Journal of Geology 100, 525-544. 2366 Molnia, B. F., 1979. Sedimentation in coastal embayments in the northern Gulf of Alaska, 2367 paper presented at Offshore Technology Conference, Houston, Tex.

2368 Molnia, B.F., 1983. Glacial Marine Sedimentation. Plenum Press, New York, 844 pp.

2369 Molnia, B.F., Post, A., 1995. Holocene history of Bering Glacier, Alaska - a prelude to the 2370 1993-1994 surge. Physical Geography 16, 87-117.

2371 Molnia, B.F. and Post, A., 2010. Surges of the Bering Glacier. Special Paper - Geological $2372 \quad$ Society of America 462, 291-316. 
2373 Montgomery, D. R., Balco, G., Willett, S. D., 2001. Climate, tectonics, and the morphology of 2374 the Andes. Geology 29, 579-582.

2375 Moon, T., Joughin, I., Smith, B., Howat, I., 2012. 21st-Century Evolution of Greenland Outlet $2376 \quad$ Glacier Velocities. Science 336, 576-578.

2377 Motyka, R.J., O'Neel, S., Connor, C.L., Echelmeyer, K.A., 2003. Twentieth century thinning of 2378 Mendenhall Glacier, Alaska, and its relationship to climate, lake calving, and glacier run2379 off. Global and Planetary Change 35, 93-112.

2380 Motyka, R. J., Truffer, M., Kuriger, E. M., Bucki, A. K., 2006. Rapid erosion of soft sediments 2381 by tidewater glacier advance: Taku Glacier, Alaska, USA. Geophysical Research Letters 33. 2382 doi: 10.1029/2006GL028467.

2383 Motyka, R.J., Truffer, M., Fahnestock, M., Mortensen, J., Rysgaard, S., Howat I., 2011.

2384 Submarine melting of the 1985 Jakobshavn Isbræ floating tongue and the triggering of the 2385 current retreat. J. Geophy. Res. 116(F1), 1-17, doi:10.1029/2009JF001632.

2386 Mugford, R.I., Dowdeswell, J.A., 2010. Modeling iceberg-rafted sedimentation in high-latitude 2387 fjord environments. J. Geophys. Res 115, F03024. doi:10.1029/2009JF001564

2388 Mugford, R.I., Dowdeswell, J.A., 2011. Modeling glacial meltwater plume dynamics and 2389 sedimentation in high-latitude fjords. J. Geophys. Res. 116(F1), 1-20, 2390 doi:10.1029/2010JF001735

2391 Mulder, T., Syvitski, J., 1995. Turbidity currents generated at river mouths during exceptional 2392 discharges to the world oceans. Journal of Geology 103, 285-299.

2393 Muñoz, Y. P., Wellner, J. S., Anderson, J. B., Minzoni, R., Fernández, R. A., 2014. Holocene 2394 accumulation rates in Antarctic Peninsula fjords from millennial to recent timescales. GSA 2395 Annual Meeting, Vancouver, British Columbia. 
Murray, T., Strozzi, T., Luckman, A., Jiskoot, H., Christakos, P., 2003. Is there a single surge mechanism? Contrasts in dynamics between glacier surges in Svalbard and other regions. Journal of Geophysical Research-Solid Earth 108(B5), 15.

Muskett, R.R., Lingle, C.S., Sauber, J.M., Post, A.S., Tangborn, W.V., Rabus, B.T., 2008.

2400 Surging, accelerating surface lowering and volume reduction of the Malaspina Glacier 2401 system, Alaska, USA, and Yukon, Canada, from 1972 to 2006. Journal of Glaciology 54, $2402 \quad 788-800$.

2403 Nesje, A., Dahl, S.O., Thun, T., Nordli, O., 2008. The 'Little Ice Age' glacial expansion in 2404 western Scandinavia: summer temperature or winter precipitation? Climate Dynamics 30, $2405 \quad 789-801$.

2406 Nick, F.M., van der Veen, C.J., Oerlemans, J., 2007. Controls on advance of tidewater glaciers: 2407 Results from numerical modeling applied to Columbia Glacier. J. Geophys. Res., 2408 112(F3),1-11, doi: 10.1029/2006JF000551.

2409 Nielsen, T., De Santis, L., Dahgren, K.I.T., Kuijpers, A., Laberg, J.S., Nygård, A., Praeg, D., 2410 Stoker, M.S., 2005. A comparison of the NW European glaciated margin with other 2411 glaciated margins. Marine and Petroleum Geology 22, 1149-1183.

2412 Noormets, R., Dowdeswell, J.A., Larter, R.D., Cofaigh, C.Ó., Evans, J., 2009. Morphology of 2413 the upper continental slope in the Bellingshausen and Amundsen Seas - Implications for 2414 sedimentary processes at the shelf edge of West Antarctica. Marine Geology 258, 100-114. 2415 Nygård, A., Sejrup, H.P., Haflidason, H., Bryn, P., 2005. The glacial North Sea Fan, southern 2416 Norwegian Margin: architecture and evolution from the upper continental slope to the deep2417 sea basin. Marine and Petroleum Geology 22, 71-84. 
2418 Nygård, A., Sejrup, H.P., Haflidason, H., Lekens, W.A.H., Clark, C.D., Bigg, G.R., 2007.

2419 Extreme sediment and ice discharge from marine-based ice streams: New evidence from the $2420 \quad$ North Sea. Geology 35, 395-398.

2421 O’Neel, S., Pfeffer, W.T., Krimmel, R.M., Meier, M., 2005. Evolving force balance at

2422 Columbia Glacier, Alaska, during its rapid retreat. J. Geophys. Res. 110, 1-18.

2423 doi:10.1029/2005JF000292

2424 Oerlemans, J., 2005. Extracting a climate signal from 169 glacier records. Science 308, 6752425677.

2426 Ohkouchi, N., Eglinton, T.I., 2008. Compound-specific radiocarbon dating of Ross Sea 2427 sediments: A prospect for constructing chronologies in high-latitude oceanic sediments. 2428 Quaternary Geochronology 3, 235-243.

2429 Olsen, L., Sveian, H., Bergstrøm, B., 2001. Rapid adjustments of the western part of the 2430 Scandinavian Ice Sheet during the mid- and late Weichselian-A new model: Norwegian $2431 \quad$ Journal of Geology 81, 93-118.

2432 Ottesen, D., Dowdeswell, J.A., 2006. Assemblages of submarine landforms produced by 2433 tidewater glaciers in Svalbard. Journal of Geophysical Research-Earth Surface, 111(F1). $2434 \quad 10.1029 / 2005 J F 000330$.

2435 Ottesen, D., Dowdeswell, J.A., 2009. An inter-ice-stream glaciated margin: Submarine 2436 landforms and a geomorphic model based on marine-geophysical data from Svalbard. 2437 Geological Society of America Bulletin 121, 1647-1665.

2438 Ottesen, D., Dowdeswell, J.A., Rise, L., 2005. Submarine landforms and the reconstruction of 2439 fast-flowing ice streams within a large Quaternary ice sheet: The 2500-km-long Norwegian- 
Svalbard margin (57 degrees-80 degrees N). Geological Society of America Bulletin 117,

$2441 \quad 1033-1050$.

2442 Ottesen, D., Dowdeswell, J.A., Landvik, J.Y., Mienert, J., 2007. Dynamics of the Late

2443 Weichselian ice sheet on Svalbard inferred from high-resolution sea-floor morphology.

$2444 \quad$ Boreas 36, 286-306.

2445 Ottesen, D., Dowdeswell, J.A., Benn, D.I., Kristensen, L., Christiansen, H.H., Christensen, O.,

2446 Hansen, L., Lebesbye, E., Forwick, M. and Vorren, T.O., 2008a. Submarine landforms

2447 characteristic of glacier surges in two Spitsbergen fjords. Quaternary Science Reviews 27,

$2448 \quad 1583-1599$.

2449 Ottesen, D., Stokes, C.R., Rise, L., Olsen, L., 2008b. Ice-sheet dynamics and ice streaming

2450 along the coastal parts of northern Norway. Quaternary Science Reviews 27, 922-940.

2451 Parish, T. R., Bromwich, D. H., 1987. The surface windfield over the Antarctic ice sheets.

$2452 \quad$ Nature 328, 51-54.

2453 Parish, T. R., Bromwich, D. H., 2007. Reexamination of the near-surface airflow over the

2454 Antarctic continent and implications on atmospheric circulations at high southern latitudes.

2455 Monthly Weather Review 135, 1961-1973.

2456 Patterson, M.O., McKay, R., Naish, T., Escutia, C., Jimenez-Espejo, F.J., Raymo, M.E.,

2457 Meyers, S.R., Tauxe, L., Brinkhuis, H., Integrated Ocean Drilling Expedition 318 Scientists,

2458 2014. Orbital forcing of the East Antarctic ice sheet during the Pliocene and Early

$2459 \quad$ Pleistocene. Nature Geosci. 7, 841-847.

2460 Pedersen, J.B.T., Kroon, A., Jakobsen, B.H., Mernild, S.H., Andersen, T.J., Andresen, C.S.,

24612013 . Fluctuations of sediment accumulation rates in front of an Arctic delta in Greenland.

$2462 \quad$ Holocene 23, 860-868. 
2463 Pedersen, V. K., Egholm, D. L., 2013. Glaciations in response to climate variations

2464 preconditioned by evolving topography. Nature 493, 206-210.

2465 Pedersen, V.K., Huismans, R.S., Herman, F., Egholm, D.L., 2014. Controls of initial

2466 topography on temporal and spatial patterns of glacial erosion. Geomorphology 223, 96-

$2467 \quad 116$.

2468 Pelto, M.S., Warren, C.R., 1991. Relationship between tidewater glacier calving velocity and 2469 water depth at the calving front. Annals of Glaciology 15, 115-118.

2470 Pelto, M.S., Higgins, S.M., Hughes, T.J., Fastook, J.L., 1990. Modeling mass-balance changes

2471 during a glaciation cycle. Ann. Glaciol. 14, 238-241.

2472 Pfeffer, W.T., 2007. A simple mechanism for irreversible tidewater glacier retreat. J. Geophys.

2473 Res. 112, 1-12. doi:10.1029/2006JF000590

2474 Phillips, A.C., Smith, N.D., Powell, R.D., 1991. Laminated sediments in prodeltaic deposits,

2475 Glacier Bay, Alaska. In: Anderson JB, and Ashley GM (Eds.), Glacial Marine

2476 Sedimentation; Paleoclimatic Significance. Geological Society America Special Paper 261,

$2477 \quad 51-60$.

2478 Pierce, E.L., Hemming, S.R., Williams, T., van de Flierdt, T., Thomson, S.N., Reiners, P.W.,

2479 Gehrels, G.E., Brachfeld, S.A., Goldstein, S.L., 2014. A comparison of detrital U-Pb zircon,

$2480 \quad{ }^{40} \mathrm{Ar} /{ }^{39} \mathrm{Ar}$ hornblende,${ }^{40} \mathrm{Ar} /{ }^{39} \mathrm{Ar}$ biotite ages in marine sediments off East Antarctica:

2481 Implications for the geology of subglacial terrains and provenance studies. Earth Science

$2482 \quad$ Reviews 138, 156-178.

2483 Pimentel, S., Flowers, G. E., 2011. A numerical study of hydrologically driven glacier

2484 dynamics and subglacial flooding. Proceedings of the Royal Society A: Mathematical,

$2485 \quad$ Physical and Engineering Science 467, 537-558. 
2486 Plassen, L., Vorren, T.O., Forwick, M., 2004. Integrated acoustic and coring investigation of 2487 glacigenic deposits in Spitsbergen fjords. Polar Research 23, 89-110.

2488 Plink-Bjorklund, P., Ronnert, L., 1999. Depositional processes and internal architecture of Late 2489 Weichselian ice-margin submarine fan and delta settings. Sedimentology 46, 215-234.

2490 Powell, R.D., 1981. A model for sedimentation by tidewater glaciers. Ann. Glaciol. 2, 129$2491 \quad 134$.

2492 Powell, R.D., 1983. Glacial-marine sedimentation processes and lithofacies of temperate 2493 tidewater glaciers, Glacier Bay, Alaska. In: B.F. Molnia (Editor), Glacial Marine 2494 Sedimentation. Plenum Press, New York, pp. 185-232.

2495 Powell, R. D.,1984. Glacimarine processes and inductive lithofacies modelling of ice shelf and 2496 tidewater glacier sediments based on Quaternary examples. Marine Geology 57, 1-52.

2497 Powell, R.D., 1990. Glacimarine processes at grounding line fans and their growth to ice2498 contact deltas. In: J.A. Dowdeswell and J.D. Scourse (Editors), Glacimarine Environments: 2499 Processes and Sediments. Geological Society Special Publication, London, pp. 53-74. 2500 Powell, R.D., 1991. Grounding-line systems as second-order controls on fluctuations of 2501 tidewater termini of temperate glaciers. In: J.B. Anderson and G.M. Ashley (Editors), 2502 Glacial Marine Sedimentation: Paleoclimatic Significance. Geological Society of America, 2503 Special Paper, Boulder, CO, pp. 75-93.

2504 Powell, R.D., Cooper, J.M., 2002. A glacial sequence stratigraphic model for temperate, 2505 glaciated continental shelves. Geological Society, London, Special Publications 203, 2152506244. 
2507 Powell, R., Domack, E., 1995. Modern glaciomarine environments. In: Menzies, J.J. (Ed.),

2508 Modern Glacial Environments: Processes, Dynamics, and Sediments. Butterworth-

2509 Heinemann, Oxford, pp. 445-486.

2510 Powell, R.D., Domack, E., 2002. Modern glaciomarine environments. In: J. Menzies (Ed.),

2511 Modern and Past Glacial Environments, Butterworth-Heinemann, Boston, pp. 361-389.

2512 Powell, R.D., Molnia, B.F., 1989. Glacimarine sedimentary processes, facies and morphology

2513 of the South Southeast Alaska shelf and fjords. Marine Geology, 85, 359-390.

2514 Powell, R.D., Dawber, M., McInnes, J.N., Pyne, A.R., 1996. Observations of the grounding-

2515 line area at a floating glacier terminus. Ann. Glaciol. 22, 217-223.

2516 Praetorius, S.K., Mix, A.C., 2014. Synchronization of North Pacific and Greenland climates

2517 preceded abrupt deglacial warming. Science 345, 444-448.

2518 Prior, D.B., Bornhold, B.D., Johns, M.W., 1986. A sand-transporting fjord-bottom channel

$2519 \quad$ system. Geology 14, 581-584.

2520 Prior, D. B., Bornhold, B. D., Wiseman, W. J., Lowe, D. R., 1987. Turbidity current activity in

2521 a British Columbia fjord. Science 237, 1330-1333.

2522 Pritchard, H., Murray, T., Luckman, A., Strozzi, T., Barr, S., 2005. Glacier surge dynamics of

2523 Sortebrae, east Greenland, from synthetic aperture radar feature tracking. Journal of

2524 Geophysical Research-Earth Surface 110(F3): 13. doi: 10.1029/2004JF000233.

2525 Radi, T., de Vernal, A., 2008. Last glacial maximum (LGM) primary productivity in the

2526 northern North Atlantic Ocean. Canadian Journal of Earth Sciences 45, 1299-1316.

2527 Raymo, M.E., Lisiecki, L., Kawamura, K., Costanza, B., 2007. Orbital forcing, timescales, and

2528 the pacing of global glaciations. Geochimica Et Cosmochimica Acta 71, A822-A822. 
2529 Raymond, C.F., 1987. How Do Glaciers Surge - A Review. Journal of Geophysical Research$2530 \quad$ Solid Earth and Planets 92(B9), 9121-9134.

2531 Rebesco, M., A. Camerlenghi, R. Geletti, M. Canals, 2006. Margin architecture reveals the 2532 transition to the modern Antarctic ice sheet ca. 3 Ma. Geology 34, 301-304.

2533 Rebesco, M., Laberg, J.S., Pedrosa, M.T., Camerlenghi, A., Lucchi, R.G., Zgur, F., Wardell, 2534 N., 2014. Onset and growth of Trough-Mouth Fans on the North-Western Barents Sea 2535 margin - implications for the evolution of the Barents Sea/Svalbard Ice Sheet. Quaternary $2536 \quad$ Science Reviews 92, 227-234.

2537 Reece, R.S., Gulick, S.P.S., Horton, B.K., Christeson, G.L., Worthington, L.L., 2011. Tectonic 2538 and climatic influence on the evolution of the Surveyor Fan and Channel system, Gulf of $2539 \quad$ Alaska. Geosphere 7, 830-844.

2540 Refsnider, K.A., Miller, G.H., Frechette, B. and Rood, D.H., 2013. A chronological framework 2541 for the Clyde Foreland Formation, Eastern Canadian Arctic, derived from amino acid 2542 racemization and cosmogenic radionuclides. Quaternary Geochronology, 16: 21-34.

2543 Reyes, A.V., Carlson, A.E., Beard, B.L., Hatfield, R.G., Stoner, J.S., Winsor, K., Welke, B., 2544 Ullman, D.J., 2014. South Greenland ice-sheet collapse during Marine Isotope Stage 11. $2545 \quad$ Nature 510, 525-528.

2546 Rignot, E., Koppes, M.N., Velicogna, I., 2010. Rapid submarine melting of the calving faces of 2547 West Greenland glaciers. Nat. Geosci. 3, 1-5, doi:10.1038/ngeo765.

2548 Rignot, E., Mouginot, J., Morlighem, M., Seroussi, H., Scheuchl, B., 2014. Widespread, rapid 2549 grounding line retreat of Pine Island, Thwaites, Smith, and Kohler glaciers, West Antarctica, $2550 \quad$ from 1992 to 2011. Geophysical Research Letters 41, 3502-3509. 
2551 Riihimaki, C. A., K. R. MacGregor, R. S. Anderson, S. P. Anderson, Loso, M.G., 2005.

2552 Sediment evacuation and glacial erosion rates at a small alpine glacier, Journal of

$2553 \quad$ Geophysical Research 110, 1-17, doi:10.1029/2004JF000189.

2554 Roe, G. H., 2005. Orographic precipitation. Annu. Rev. Earth Planet. Sci. 33, 645-671.

2555 Roe, G.H., Baker, M.B., 2014. Glacier response to climate perturbations: an accurate linear

2556 geometric model. Journal of Glaciology 60, 670-684.

2557 Roksandic, M.M., 1979. Geology of the continental shelf off West Greenland between

$255861^{\circ} 150 \mathrm{~N}$ and $64^{\circ} 000 \mathrm{~N}$ : an interpretation of sparker seismic and echosounder data.

2559 Grønlands Geologiske Undersøgelse 92, 15.

2560 Romans, B.W., Castelltort, S., Covault, J.A., Fildani, A., Walsh, J.P., 2015. Environmental

2561 signal propagation in sedimentary systems across timescales. Earth Science Reviews, this

2562 volume.

2563 Rosenheim, B.E., Day, M.B., Domack, E., Schrum, H., Benthien, A., Hayes, J.M., 2008.

2564 Antarctic sediment chronology by programmed-temperature pyrolysis: Methodology and

2565 data treatment. Geochemistry Geophysics Geosystems 9, 10.1029/2007gc001816.

2566 Rother, H., Fink, D., Shulmeister, J., Mifsud, C., Evans, M., Pugh, J., 2014. The early rise and

2567 late demise of New Zealand's last glacial maximum. Proceedings of the National Academy

2568 of Sciences 111, 11630-11635.

2569 Ruddiman, W. F., 1977. Late Quaternary deposition of ice-rafted sand in the sub-polar North

2570 Atlantic $\left(40-60^{\circ} \mathrm{N}\right)$, Geol. Soc. Am. Bull. 88, 1813-1827.

2571 Salcedo-Castro, J., Bourgault, D., Bentley, S.J., deYoung, B., 2013. Non-hydrostatic modeling

2572 of cohesive sediment transport associated with a subglacial buoyant jet in glacial fjords: A

2573 process-oriented approach. Ocean Model. 63, 30-39, doi:10.1016/j.ocemod.2012.12.005. 
2574 Schoof, C., 2010. Ice-sheet acceleration driven by melt supply variability. Nature 468, 803-6, 2575 doi:10.1038/nature09618.

2576 Schumann, K., Völker, D., Weinrebe, W.R., 2012. Acoustic mapping of the Ilulissat Ice Fjord 2577 mouth, West Greenland. Quat. Sci. Rev. 40, 78-88.

2578 Shackleton, N.J., 1987. Oxygen isostopes, ice volume and sea level. Quaternary Science $2579 \quad$ Reviews 6, 183-190.

2580 Sheaf, M.A., Serpa, L., Pavlis, T.L., 2003. Exhumation rates in the St. Elias Mountains, $2581 \quad$ Alaska. Tectonophysics 367, 1-11.

2582 Shipp, S.S., Wellner, J.S., Anderson, J.B., 2002. Retreat signature of a polar ice stream: sub2583 glacial geomorphic features and sediments from the Ross Sea, Antarctica. Geological $2584 \quad$ Society Special Publication 203, 277-304.

2585 Shuster, D.L., Ehlers, T.A., Rusmore, M.E., Farley, K.A., 2005. Rapid glacial erosion at 1.8 $2586 \quad$ Ma revealed by ${ }^{4} \mathrm{He} /{ }^{3} \mathrm{He}$ thermochronometry. Science $310,1668-1670$.

2587 Siegert, M.J., 1993. Numerical modelling studies of the Svalbard- Barents Sea Ice Sheet. $2588 \quad$ Unpublished Ph.D. Thesis, University of Cambridge.

2589 Siegert, M.J., Dowdeswell, J.A., 1995. Numerical modeling of the Late Weichselian Svalbard$2590 \quad$ Barents Sea Ice Sheet. Quaternary Research 43, 1-13.

2591 Siegert, M. J., Dowdeswell, J. A., 2002. Late Weichselian iceberg, surface-melt and sediment 2592 production from the Eurasian Ice Sheet: results from numerical ice-sheet modelling. Marine $2593 \quad$ Geology 188, 109-127.

2594 Siegert, M.J., Dowdeswell, J.A., Melles, M., 1999. Late Weichselian glaciation of the Eurasian 2595 High Arctic. Quaternary Research 52, 273-285. 
2596 Siegert, M. J., Dowdeswell, J. A., 2004. Numerical reconstructions of the Eurasian Ice Sheet 2597 and climate during the Late Weichselian. Quaternary Science Reviews 23, 1273-1283.

2598 Simon, Q., Hillaire-Marcel, C., St-Onge, G., Andrews, J.T., 2014. Northeastern Laurentide, 2599 western Greenland and southern Innuitian ice stream dynamics during the last glacial cycle. 2600 Journal of Quaternary Science 29, 14-26.

2601 Simon, Q., St-Onge, G., Hillaire-Marcel, C., 2012. Late Quaternary chronostratigraphic 2602 framework of deep Baffin Bay glaciomarine sediments from high-resolution paleomagnetic 2603 data. Geochemistry Geophysics Geosystems 13, 24. doi: 10.1029/2012GC004272.

2604 Smith, L.M., Andrews, J.T., 2000. Sediment characteristics in iceberg dominated fjords, 2605 Kangerlussuaq region, East Greenland. Sediment Geol. 130, 11-25.

2606 Smith, N.D., Phillips, A.C., Powell, R.D., 1990. Tidal drawdown: A mechanism for producing 2607 cyclic sediment laminations in glaciomarine deltas. Geology 18, 10-13.

2608 Solheim, A., Faleide, J.I., Andersen, E.S., Elverhoi, A., Forsberg, C.F., Vanneste, K., 2609 Uenzelmann-Neben, G., Channell, J.E.T., 1998. Late Cenozoic seismic stratigraphy and 2610 glacial geological development of the East Greenland and Svalbard Barents Sea continental 2611 margins. Quaternary Science Reviews 17,155-184.

2612 St. John, K.E.K., Krissek, L.A., 1999. Regional patterns of Pleistocene ice-rafted debris flux in 2613 the North Pacific. Paleoceanography 14, 653-662.

2614 Steffen, K., Box, J., 2001. Surface climatology of the Greenland ice sheet: Greenland climate 2615 network 1995-1999. Journal of Geophysical Research-Atmospheres 106(D24), 33951$2616 \quad 33964$.

2617 Stock, J. D., Montgomery, D. R., 1999. Geologic constraints on bedrock river incision using 2618 the stream power law. Journal of Geophysical Research: Solid Earth 104(B3), 4983-4993. 
2619 Stokes, C.R., Clark, C.D., 2001. Palaeo-ice streams. Quaternary Science Reviews 20, 1437$2620 \quad 1457$.

2621 Stokes, C.R., Tarasov, L., 2010. Ice streaming in the Laurentide Ice Sheet: A first comparison 2622 between data-calibrated numerical model output and geological evidence. Geophysical 2623 Research Letters, 37. doi: 10.1029/2009GL040990.

2624 Stokes, C.R., Clark, C.D., Darby, D.A., Hodgson, D., 2005. Late Pleistocene ice export events 2625 into the Arctic Ocean from the M'Clure Strait Ice Stream, Canadian Arctic Archipelago. 2626 Glob. Planet Chang. 49, 139-162.

2627 Stoner, J.S., Channell, J.E.T., Hillaire-Marcel, C., Kissel, C., 2000. Geomagnetic paleointensity 2628 and environmental record from Labrador Sea core MD95-2024: global marine sediment and 2629 ice core chronostratigraphy for the last 110 kyr. Earth and Planetary Science Letters 183, $2630 \quad 161-177$.

2631 Straneo, F., Heimbach, P., Sergienko, O., Hamilton, G., Catania, G., Griffies, S., Vieli, A., 2632 2013. Challenges to understanding the dynamic response of Greenland's marine terminating 2633 glaciers to oceanic and atmospheric forcing. Bulletin of the American Meteorological $2634 \quad$ Society $94,1131-1144$.

2635 Straneo, F., Heimbach, P., 2013. North Atlantic warming and the retreat of Greenland's outlet 2636 glaciers. Nature 504, 36-43.

2637 Straneo, F., Curry, R.G., Sutherland, D.A., Hamilton, G.S., Cenedese, C., Våge, K., Stearns, 2638 L.A., 2011. Impact of fjord dynamics and glacial runoff on the circulation near Helheim 2639 Glacier. Nat. Geosci. 4, 322-327, doi:10.1038/ngeo1109. 
2640 Striberger, J., Bjorck, S., Benediktsson, I.O., Snowball, I., Uvo, C.B., Ingolfsson, O., Kjaer,

2641 K.H., 2011. Climatic control of the surge periodicity of an Icelandic outlet glacier. Journal 2642 of Quaternary Science 26, 561-565.

2643 Stroeven, A.P., Fabel, D., Hatterstrand, C., Harbor, J. A., 2002. Relict landscape in the centre 2644 of the Fennoscandian glaciation: cosmogenic radionuclide evidence of tors preserved 2645 through multiple glacial cycles. Geomorphology 44, 145-154.

2646 Svendsen, J.I., Mangerud, J., 1997. Holocene glacial and climatic variations on Spitsbergen, 2647 Svalbard. The Holocene 7, 45-57.

2648 Svendsen, H., Beszczynska-Møller, A., Hagen, J.O., et al., 2002. The physical environment of 2649 Kongsfjorden-Krossfjorden, an Arctic fjord system in Svalbard. Polar Research 21, 133$2650 \quad 166$.

2651 Svendsen, J.I., Mangerud, J., Elverhoi, A., Solheim, A. and Schuttenhelm, R.T.E., 1992. The 2652 Late Weichselian Glacial Maximum on Western Spitsbergen inferred from offshore 2653 sediment cores. Marine Geology 104, 1-17.

2654 Svendsen, J.I., Astakov, V.I., Bolshiyanov, D.Y., Demidov, I., Dowdeswell, J.A., Gataullin, V., 2655 Hjort, C., Hubberten, H.W., Larsen, E., Mangerud, J., Melles, M., Moller, P., Saarnisto, M., 2656 Siegert, M.J., 1999. Maximum extent of the Eurasian ice sheets in the Barents and Kara Sea 2657 region during the Weichselian. Boreas 28, 234-242.

2658 Svendsen, J.I., Alexanderson, H., Astakhov, V.I., Demidov, I., Dowdeswell, J.A., Funder, S., 2659 Gataullin, V., Henriksen, M., Hjort, C., Houmark-Nielsen, M., Hubberten, H.W., 2660 Ingolfsson, O., Jakobsson, M., Kjaer, K.H., Larsen, E., Lokrantz, H., Lunkka, J.P., Lysa, A., 2661 Mangerud, J., Matiouchkov, A., Murray, A., Moller, P., Niessen, F., Nikolskaya, O., Polyak, 2662 L., Saarnisto, M., Siegert, C., Siegert, M.J., Spielhagen, R.F., Stein, R., 2004. Late 

1271.

2665 Swift, D. A., Persano, C., Stuart, F. M., Gallagher, K., Whitham, A., 2008. A reassessment of 2666 the role of ice sheet glaciation in the long-term evolution of the East Greenland fjord region. 2667 Geomorphology 97, 109-125.

2668 Swift, D.A., Nienow, P.W., Hoey, T.B., 2005. Basal sediment evacuation by subglacial 2669 meltwater: suspended sediment transport from Haut Glacier d'Arolla, Switzerland. Earth $2670 \quad$ Surf. Process. Landforms 30, 867-883, doi:10.1002/esp.1197.

2671 Syvitski, J. P.M., 1989. On the deposition of sediment within glacier-influenced fjords: 2672 oceanographic controls. Mar. Geol. 85, 301-329.

2673 Syvitski, J.P.M., Shaw, J., 1995. Sedimentology and geomorphology of fjords. In: G.M.E. 2674 Perillo (Editor), Geomorphology and Sedimentology of Estuaries: Developments in 2675 Sedimentology. Elsevier, New York, pp. 113-178.

2676 Syvitski, J.P.M., Burrell, D.C., Skei, J.M., 1987. Fjords: Processes and Products. Springer 2677 Verlag, New York, 379 pp.

2678 Syvitski, J.P.M., Andrews, J.T., Dowdeswell, J.A., 1996. Sediment deposition in an iceberg2679 dominated glacimarine environment, East Greenland: basin fill implications. Global and $2680 \quad$ Planetary Change 12, 251-270.

2681 Szczucinski, W., Zajaczkowski, M., Scholten, J., 2009. Sediment accumulation rates in 2682 subpolar fjords - Impact of post-Little Ice Age glaciers retreat, Billefjorden, Svalbard. 2683 Estuarine, Coastal and Shelf Science 85, 345-356, doi:10.1016/j.ecss.2009.08.021.

2684 Szczucinski, W., Zajaczkowski, M., 2012. Factors controlling downward fluxes of particulate 2685 matter in glacier-contact and non-glacier contact settings in a subpolar fjord (Billefjorden, 
Svalbard). In: Sediments, Morphology and Sedimentary Processes on Continental Shelves, vol. 44, edited by M.Z. Li, C.R. Sherwood, and P.R. Hill, International Association of Sedimentologists, Wiley-Blackwell, Oxford, UK, p. 369-386.

Taylor, J., Dowdeswell, J.A., Kenyon, N.H., Cofaigh, C.Ó, 2002a. Late Quaternary architecture of trough-mouth fans: debris flows and suspended sediments on the Norwegian margin. Geological Society, London, Special Publications 203, 55-71.

Taylor, J., Dowdeswell, J.A., Siegert, M.J., 2002b. Late Weichselian depositional processes, fluxes, and sediment volumes on the margins of the Norwegian Sea $\left(62-75^{\circ} \mathrm{N}\right)$. Marine Geology 188; 61-77.

Taylor, J., Tranter, M., Munhoven, G., 2002c. Carbon cycling and burial in the glacially influenced polar North Atlantic. Paleoceanography, 17(1). 10.1029/2001PA000644. events recorded in the stratigraphy of the tropical Quelccaya ice cap, Peru. Science 226, 5053.

2703 Tomkin, J. H., 2007. Coupling glacial erosion and tectonics at active orogens: A numerical 2704

Thomson, S.N., Brandon, M.T., Tomkin, J.H., Reiners, P.W., Vásquez, C., Wilson, N. J., 2010. Glaciation as a destructive and constructive control on mountain building. Nature 467, 3137, doi:10.1038/nature09365 modeling study. Journal of Geophysical Research: Earth Surface (2003-2012), 112(F2).

Tomkin, J. H., 2009. Numerically simulating alpine landscapes: the geomorphologic consequences of incorporating glacial erosion in surface process models. Geomorphology $103,180-188$. 
2708 Tomkin, J. H., Braun, J., 2002. The influence of alpine glaciation on the relief of tectonically 2709 active mountain belts. American Journal of Science 302, 169-190.

2710 Tremblay, M. M., Shuster, D. L., Balco, G., 2014. Cosmogenic noble gas paleothermometry. 2711 Earth and Planetary Science Letters 400, 195-205.

2712 Tripati, A.K., Eagle, R.A., Morton, A., Dowdeswell, J.A., Atkinson, K.L., Bahe, Y., Dawber,

2713 C.F., Khadun, E., Shaw, R.M.H., Shorttle, O., Thanabalasundaram, L., 2008. Evidence for 2714 glaciation in the Northern Hemisphere back to 44 Ma from ice-rafted debris in the 2715 Greenland Sea. Earth and Planetary Science Letters 265; 112-122.

2716 Truffer, M., Motyka, R. J., Harrison, W. D., Echelmeyer, K. A., Fisk, B., Tulaczyk, S., 1999. 2717 Subglacial drilling at Black Rapids Glacier, Alaska, USA: drilling method and sample 2718 descriptions. Journal of Glaciology 45, 495-505.

2719 Tulaczyk, S.B., Scherer, R.P., Clark, C.D., 2001. A ploughing model for the origin of weak 2720 tills beneath ice steams: a qualitative treatment. Quaternary International 86, 59-70.

2721 Van der Veen, C., 1996. Tidewater calving. Journal of Glaciology 42, 375-385.

2722 Vorren, T. O., Richardsen, G. Knutsen, S., Henriksen, E., 1991. Cenozoic erosion and 2723 sedimentation in the western Barents Sea. Marine and Petroleum Geology 8, 317-340.

2724 Vorren, T.O., Laberg, J.S., 1997. Trough mouth fans - Palaeoclimate and ice-sheet monitors. 2725 Quaternary Science Reviews 16, 865-881.

2726 Vorren, T.O., Hald, M., Lebesbye, E., 1988. Late Cenozoic Environments in the Barents Sea. $2727 \quad$ Paleoceanography 3, 601-612.

2728 Vorren, T.O., Laberg, J.S., Blaume, F., Dowdeswell, J.A., Kenyon, N.H., Mienert, J., Rumohr, 2729 J., Werner, F., 1998. The Norwegian Greenland Sea continental margins: Morphology and 
late Quaternary sedimentary processes and environment. Quaternary Science Reviews 17, 273-302.

2732 Walton, M.A.L., Gulick, S.P.S., Reece, R.S., Barth, G.A., Christeson, G.L., Van Avendonk,

2733 H.J.A., 2014. Dynamic response to strike-slip tectonic control on the deposition and 2734 evolution of the Baranof Fan, Gulf of Alaska. Geosphere 10; 680-691.

2735 Warren, C., Aniya, M., 1999. The calving glaciers of southern South America. Global and $2736 \quad$ Planetary Change 22; 59-77.

2737 Warren, C.R., Glasser, N.F., Harrison, S., Winchester, V., Kerr, A.R., Rivera, A., 1995.

2738 Characteristics of tidewater calving at Glaciar San Rafael, Chile. J. Glaciol. 41, 273-289.

2739 Wellner, J. S., Lowe, A. L., Shipp, S. S., Anderson, J. B. 2001. Distribution of glacial

2740 geomorphic features on the Antarctic continental shelf and correlation with substrate:

2741 implications for ice behavior. Journal of Glaciology 47, 397-411.

2742 Wellner, J.S., Heroy, D.C., Anderson, J.B., 2006. The death mask of the Antarctic Ice Sheet:

2743 Comparison of glacial geomorphic features across the continental shelf. Geomorphology 75, $2744 \quad 157-171$.

2745 Wiles, G.C., Barclay, D.J., Calkin, P.E., Lowell, T.V., 2008. Century to millennial-scale 2746 temperature variations for the last two thousand years indicated from glacial geologic 2747 records of Southern Alaska. Global and Planetary Change 60, 115-125.

2748 Wiles, G.C., Post, A., Muller, E.H., Molnia, B.F., 1999. Dendrochronology and late Holocene 2749 history of Bering Piedmont Glacier, Alaska. Quaternary Research 52, 185-195.

2750 Wilken, M., Mienert, J., 2006. Submarine glacigenic debris flows, deep-sea channels and past 2751 ice-stream behaviour of the East Greenland continental margin. Quaternary Science 2752 Reviews 25, 784-810. 
2753 Willems, B.A., Powell, R.D., Cowan, E.A., Jaeger, J.M., 2011. Glacial outburst flood 2754 sediments within Disenchantment Bay, Alaska: Implications of recognizing marine 2755 jökulhlaup deposits in the stratigraphic record. Mar. Geol. 284; 1-12

2756 Winsborrow, M.C.M., Clark, C.D., Stokes, C.R., 2010. What controls the location of ice 2757 streams? Earth-Science Reviews 103, 45-59.

2758 Winsor, K., Carlson, A.E., Rood, D.H., 2014. Be-10 dating of the Narsarsuaq moraine in 2759 southernmost Greenland: evidence for a late Holocene ice advance exceeding the Little Ice $2760 \quad$ Age maximum. Quaternary Science Reviews 98, 135-143.

2761 Worthington, L. L., Gulick, S. P. S., Pavlis, T. L., 2010. Coupled stratigraphic and structural 2762 evolution of a glaciated orogenic wedge, offshore St. Elias orogen, Alaska. Tectonics 29, 2763 DOI: $10.1029 / 2010 \mathrm{TC} 002723$.

2764 Yanites, B.J., Ehlers, T.A., 2012. Global climate and tectonic controls on the denudation of 2765 glaciated mountains. Earth and Planetary Science Letters 325-326, 63-75.

2766 Yoon, H., B. Park, Domack E., 1998. Distribution and dispersal pattern of suspended 2767 particulate matter in Maxwell Bay and its tributary Marian Cove, in the South Shetland 2768 Islands, West Antarctica. Mar. Geol. 152, 261-275. 


\section{Figure Captions}

2770 Figure 1. Overview of glacigenic "signal" production and transfer through a glaciated source-to-

2771 sink system. In upper panel, modern high-latitude ice position shown in blue with hypothetical

2772 Neoglacial and Pleistocene ice positions shown as orange dashed lines. In lower panel, ice

2773 responds to climate forcing (blue curve), eroding the bed and creating a sedimentary signal

2774 (brown curve) that is reduced in intensity and is lagged in time as it moves through the transfer

2775 zone (fjord, shelf) to ultimately accumulate in the marine sink. Modified from Romans et al. (this

2776 volume).

2778 Figure 2. Several scenarios of glacigenic "signal" transfer through the morphodynamic segments

2779 of glacial sediment dispersal systems. Four typical climate-forced scenarios of ice response, from

2780 the seasonal to the 100-kyr timescales, are displayed in column A. Relative rates of glacigenic

2781 sediment flux as a function of climatic forcing in each dispersal segment are presented in

2782 columns B-F, as viewed from a modeling or an observational perspective. The timescale (rows)

2783 reflects the characteristic response time for glaciers to difference climatic forcings. The

2784 glacigenic depositional signal will vary in space and time depending on the proximity to the ice

2785 margin, periodic coverage by flowing ice, and the number of intervening basins to trap the

2786 signal. For example, under modern conditions (top row), annual cycles of glacial meltwater

2787 discharge are expected to generate an annual sediment pulse that deposits a signal in the glacier

2788 foreland and in fjords but is not recorded in open marine conditions. However, signals produced

2789 at all timescales have the potential to be recorded in the glacier foreland to the deep sea

2790 depending on the relative ice extent within the transfer zone. See text for additional explanation

2791 of scenarios. 
2793 Figure 3. Comparison of short-term and long-term erosion rates measured using a range of 2794 chronometric techniques from the same glaciated basins in Alaska, Patagonia, and the Coast and 2795 Cascade Mountains of Washington State and British Columbia. Boxes represent the range of 2796 erosion rates, including uncertainty in estimation (height) and timescale of measurement (width). 2797 Chronometric techniques used to quantify erosion rate, and the timescales of measurement, are at 2798 bottom. Modified from Koppes and Montgomery (2009).

2800 Figure 4. Modes of glacial erosion, sediment production and sediment transfer. (A) Quarrying 2801 (plucking) and abrasion are the dominant mechanical processes of erosion at the glacier bed, and 2802 both are a function of ice motion and subglacial water pressure. (B) Stick-slip cycle of basal 2803 motion in a deformable bed under an ice stream, showing the importance of the modulation of 2804 subglacial water pressure for motion and deformation (From Boulton et al., 2001; Bennett 2003).

2806 Figure 5. Sediment yield and sliding speed over the period of the 1981-1983 surge of Variegated 2807 Glacier. Dashed line represents linear regression relationship used to define constants of 2808 proportionality used in 'erosion rule' of $\mathrm{n}=1$ and $\mathrm{K}_{\mathrm{g}}=10^{-4}$. Year of observation noted next to 2809 data point. From Humphrey and Raymond (1994).

2811 Figure 6. Comparison of modern $\left(10^{0}-10^{1}\right)$ glacial erosion rates (triangles) and fluvial erosion 2812 rates (circles) derived from sediment yields according to catchment area, revised from data 2813 originally compiled by Hallet et al. (1996). Black triangles represent temperate tidewater glaciers 2814 from Alaska and Patagonia, gray triangles other alpine and high-latitude glaciers, black open 
2815 circles are major river basins worldwide (from Milliman and Syvitski, 1992) and mountain

2816 basins in British Columbia (from Church and Slaymaker, 1989), and grey open circles are from

2817 partially glaciated mountain basins in the high Himalaya. Modified from Koppes and Hallet

2818 (2006).

2819

2820 Figure 7. Conceptual model for proglacial depositional processes and characteristic lithofacies in

2821 fjords and on continental shelves. Top panel (A) represents a polar, ice stream-influenced

2822 continental-shelf environment. Bottom panel (B) represents a temperate-polythermal tidewater

2823 glacier environment. From Hambrey and Glasser (2012).

2824

2825 Figure 8. A schematic landform-assemblage model for temperate, meltwater-dominated fjords

2826 subject to relatively mild climatic and oceanographic conditions, such as the fjords of Patagonia

2827 or Alaska. Inset shows the efflux of a subglacial meltwater channel at the tidewater glacier

2828 terminus and the plume of turbid sediment and ice-proximal fan produced beyond the subglacial

2829 outflow mouth. From Dowdeswell and Vásquez (2013).

2830

2831 Figure 9. Location of paleo-ice streams and cross-margin troughs in the Arctic and Antarctic (A)

2832 Locations of circum-Arctic cross-shelf troughs (red; Batchelor and Dowdeswell, 2014) displayed

2833 on IBCAO bathymetric data (Jakobsson et al., 2012). Three types of continental slopes are

2834 shown. Numbers refer to specific ice streams discussed in Batchelor and Dowdeswell (2014).

2835 Approximate locations of cross-shelf troughs in Gulf of Alaska shown in red (after Carlson et al.,

2836 1982) (B) Location (blue arrows) and chronology of initial deglaciation (colored dots) for

2837 Antarctic paleo-ice streams. Dates (in black) represent initial retreat of the palaeo-ice streams; 
2838 dates in grey refer to initial retreat of the ice sheet margin. The black line shows the

2839 reconstructed position of grounded ice at the LGM. The dashed line indicates approximate

2840 grounding-line positions due to a paucity of data. From Livingstone et al. (2012).

2841

2842 Figure 10. Assemblages of submarine landforms on continental shelves typical of inter-ice-

2843 stream (A) and paleo ice-stream (B) sedimentary environments. From Dowdeswell et al. (2008b)

2844 and Ottesen and Dowdeswell (2009).

2845

2846 Figure 11. Conceptual model of glacigenic sedimentation on a high-latitude trough-mouth fan.

2847 Dominant sediment transfer mechanisms include gravity flows, meltwater discharge plumes and

2848 iceberg rafting. Idealized lithofacies assemblages across the fan are shown. From Cofaigh et al.

2849 (2013).

2850

2851 Figure 12. Cartoon interpretation of the seismic stratigraphic record of the LIA advance and

2852 subsequent retreat of San Rafael Glacier, North Patagonian Icefield, and the associated

2853 sedimentary sequences found in Laguna San Rafael, the ice-proximal fjord. Pre-LIA

2854 unconsolidated sediment deposited by turbid meltwater plumes and IRD before the start of the

2855 LIA advance event ( $<1675$ AD) and subsequently reworked by advancing ice in tan. Newly

2856 generated sediment from the glacier catchment and fjord sediments remobilized and redeposited

2857 during LIA advance and maximum extent in burgundy. Newly generated sediments eroded

2858 during $20^{\text {th }}$ century retreat in olive. Duration of LIA advance, maximum stillstand and retreat are

2859 derived from early navigational maps and aerial photography. Grey indicates top of eroded and 
2860 reworked pre-LIA sediment consolidated by overriding ice during LIA advance-retreat cycle,

2861 noted in seismic profiles as a strong subbottom reflector. Modified from Koppes et al. (2010).

2862

2863 Figure 13. Two examples of continental slope sedimentary records of LGM ice extent. (A, Top)

2864 Comparison of North Pacific/Cordilleran ice extent with the North Atlantic, from Hendy and

2865 Cosma (2008). A = Ice-rafted debris or IRD, B =Percent of terrigenous sediment, 2-4 $\mu \mathrm{m}$ (red),

$2866 \mathrm{C}=$ Sedimentation rate $\left(\mathrm{cm} \mathrm{ka}^{-1}\right), \mathrm{D}=$ Core lithology and interpretation, $\mathrm{E}=\mathrm{N}$. pachyderma $\delta^{18} \mathrm{O}$

2867 (MD02-2496, Vancouver Island), $\mathrm{F}=$ Comparison with GISP2 $\delta^{18} \mathrm{O}$ from the Greenland Ice

2868 Sheet. Major climate events correlate between the core and GISP2 (interstadials dashed red line;

2869 North Atlantic Heinrich events (H1-H5) dashed green lines). (B, Bottom) Terrigenous and IRD

2870 accumulation rates from the continental slope east of Scoresby Sund, East Greenland, from

2871 Funder et al. (1998). Amount of IRD and flux rates of terrigenous sediment plotted versus

2872 reservoir-corrected radiocarbon ages. Shaded intervals indicate timing of major pulses of IRD

2873 discharge associated with maximum ice extent and subsequent retreat.

2874

2875 Figure 14. Two examples of chronostratigraphic control of seismic reflection data. (A, Top)

2876 Correlation of seismic units (debris flow units) in the trough-mouth fans of northeastern

2877 Atlantic/Barents Sea margin with MIS (marine isotope stages) from global oxygen isotopic

2878 stratigraphy. Debris flows are assumed to occur during periods of maximum ice extent across

2879 shelves. From Vorren and Laberg (1997). (B, Bottom) Integrated seismic and core stratigraphy,

2880 Norwegian Channel Ice Stream, from Nygård et al. (2007). B1: Oxygen isotope $\left(\delta^{18} \mathrm{O}\right)$ profile

2881 [N. pach. $(s)]$ and calibrated radiocarbon ages of core MD99-2283; B2: Along-slope deep-tow

2882 boomer profile with interpreted reflectors R1-R5, showing position of core MD99-2283; B3: 
2883 Interpreted single airgun profile shot alongside boomer profile, showing regional stratigraphy.

2884 Light gray shading indicates glacigenic debris flows; dark gray indicates slide debrites; white

2885 background represents layered sediments of hemipelagic origin.

2887 Figure 15. Simplified Baffin Bay paleogeography during the last glacial cycle. (a) Partially open

2888 bay characterized by IRD sediments originating from the northern ice streams (yellow, brown

2889 arrows), and by meltwater plumes from Baffin Island ice streams (blue arrows). West Greeland

2890 Current traps GIS IRD along coast. (b) Full glacial mode characterized by Greenland and Baffin

2891 Island diamicts corresponding to a permanently ice-covered bay, and by extended fast-flowing

2892 ice streams feeding an ice shelf in the bay. From Simon et al. (2014).

2894 Figure 16. Measured (solid) and hypothesized (dashed) sedimentation rates for the Lofoten 2895 Basin, Norwegian Sea based on seismic stratigraphic interpretation. Gravity flows (large mass 2896 failures and glacigenic debris flows) are the volumetrically dominant sediment transfer 2897 mechanism for this glacier-influenced margin during at least the last 30-100 ka. Notable 2898 contrasts exist between glacial and interglacial sedimentation rates associated with the mode of 2899 sediment supply, with the majority of sediments accumulating in a short time span during glacial 2900 periods. Variations in rates reflect the time varying sediment input to the Bjørnøya trough mouth 2901 fan, the Lofoten Channel and elevated glacial hemipelagic rates. Note breaks in sedimentation 2902 rate scale. Smoothed GRIP $\delta^{18} \mathrm{O}$ record (in grey) and marine oxygen isotope stages for timescale. 2903 From Taylor et al. (2002b). 
2905 Figure 17. Cartoon of flux of glacigenic sediment over a 100-kyr glacial cycle on a high-latitude 2906 continental shelf and slope, Great Challenger Basin, Antarctica. Sediment volumes derived from 2907 seismic isopachs and a long drill-core record. Sediment at the shelf edge (right panel) is

2908 partitioned into new sediment generated by glacial erosion in the drainage basin (grey) and 2909 sediment reworked and recycled in prograding grounding zone wedge (GZW) (black). Average 2910 position of the ice margin at $20 \mathrm{ky}$ time slices, and average sediment flux for each time slice, are 2911 highlighted. From Bart and Owolana (2012).

2913 Figure 18. Modeled changes in predicted ice-sheet parameters and sedimentation rates over the 2914 past 30 k.y. for the Barents-Kara and Scandinavian ice sheets, derived from the QUEEN ice2915 sheet-landscape model. (A) Ice sheet volume, in $10^{3} \mathrm{~km}^{3}$. (B) Annual winter mass balance of ice 2916 sheet (ice accumulation), in $\mathrm{km}^{3} \mathrm{yr}^{-1}$. (C) Annual volume of iceberg calving, in $\mathrm{km}^{3}$. (D-E) The 2917 rate of model-predicted sediment delivery along transects across the western and northern 2918 Eurasian continental margin, for (D) Barents Sea-Svalbard margin and (E) Arctic Ocean margin

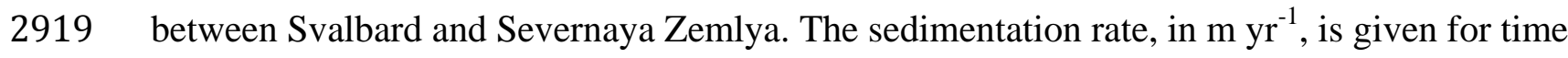
2920 slices at 25, 20, and 15 k.y. The highest sedimentation rates are associated with collapse of the 2921 ice streams. From Dowdeswell and Siegert (1999). 
SOURCE

\section{EROSION ZONE}

TRANSFER ZONE

\begin{abstract}
Glacier
\end{abstract}
dynamics
Glacier

foreland
Fjord depocenters
Shelf

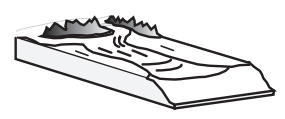

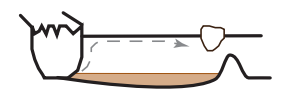

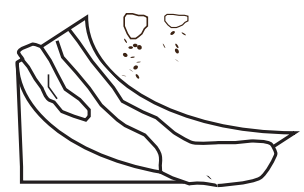

Slope

Deep Sea

SINK

ACCUMULATION ZONE
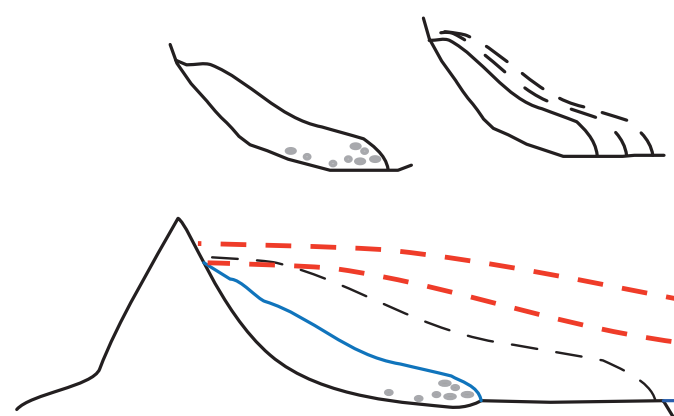

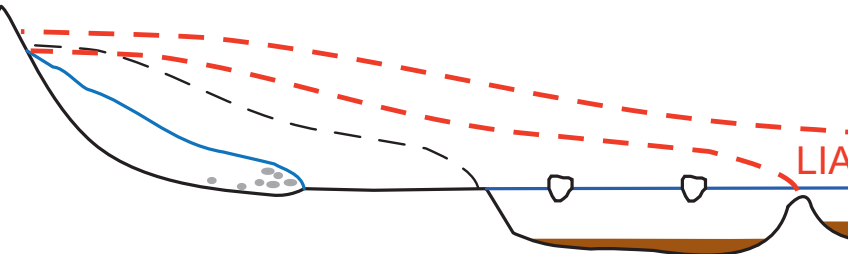

\section{SIGNAL TRANSFER}

Forcing

(thermal regime, melt season,

surge,

advance-retreat cycle, glacial-interglacial cycle)

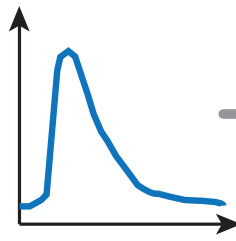

Time

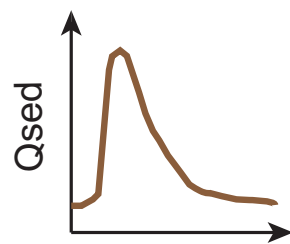

Sedimentary signal at boundary of erosion zone (glacier terminus, calving margin)

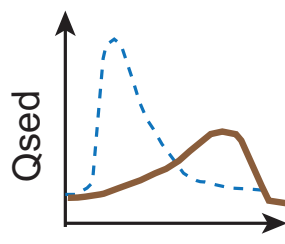


Jaeger\&Koppes_FinalFig2

Glacier dynamics

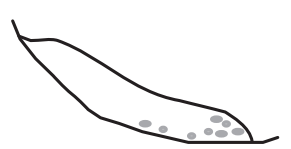

A.
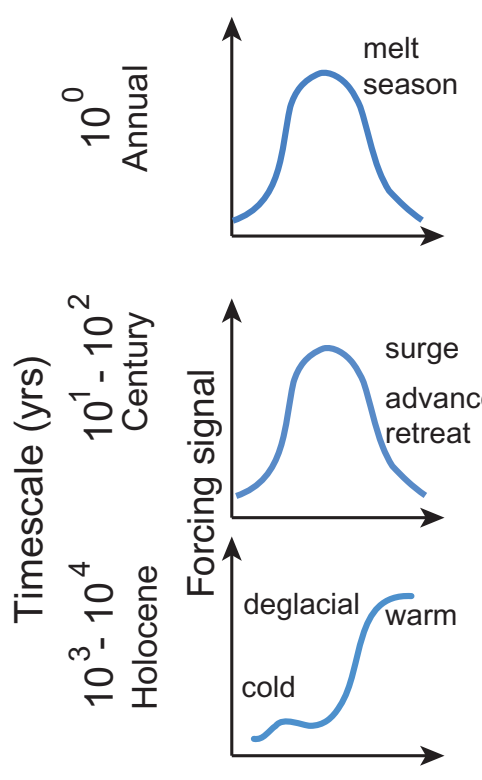

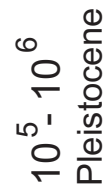

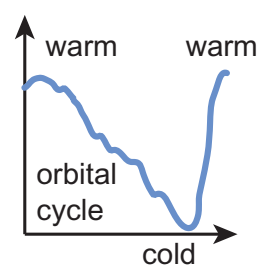

Glacier foreland

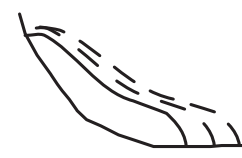

B.
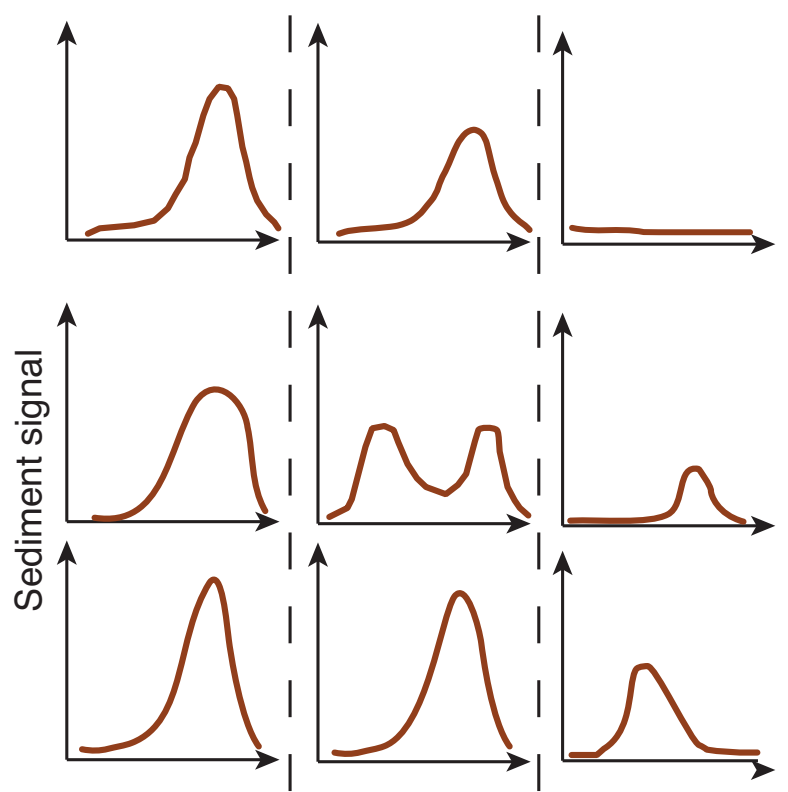

Slope

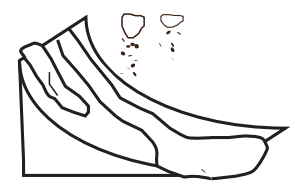

E.

I

D.
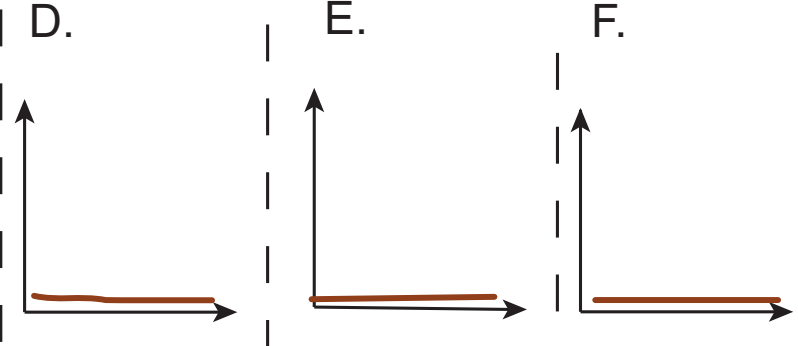

Deep Sea
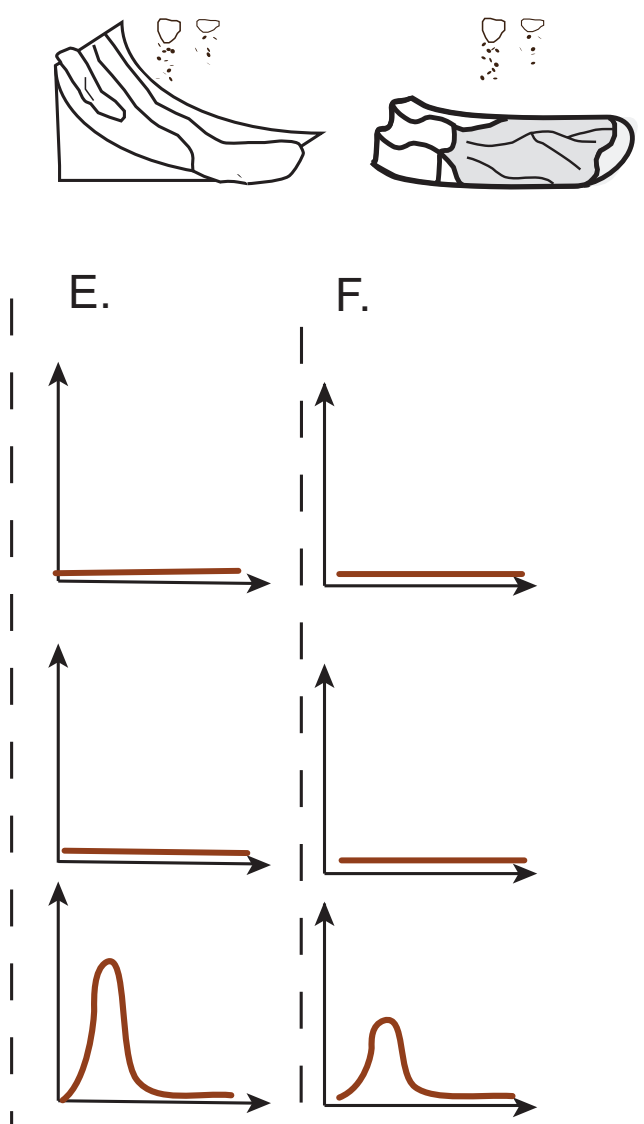
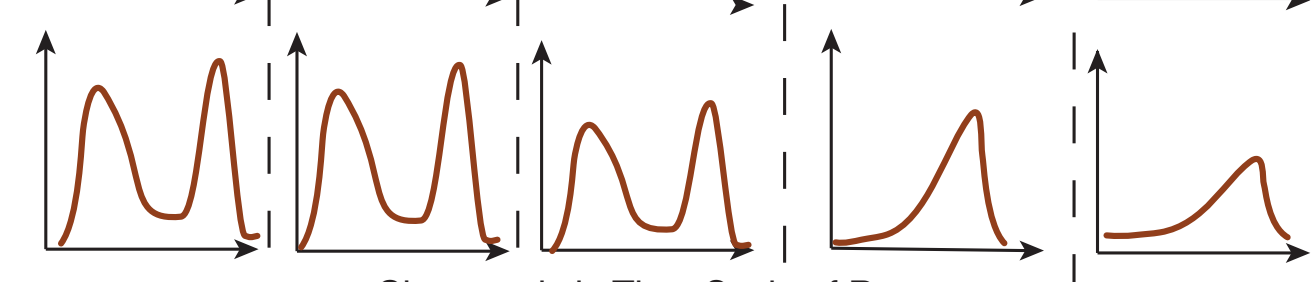

Characteristic Time Scale of Response 


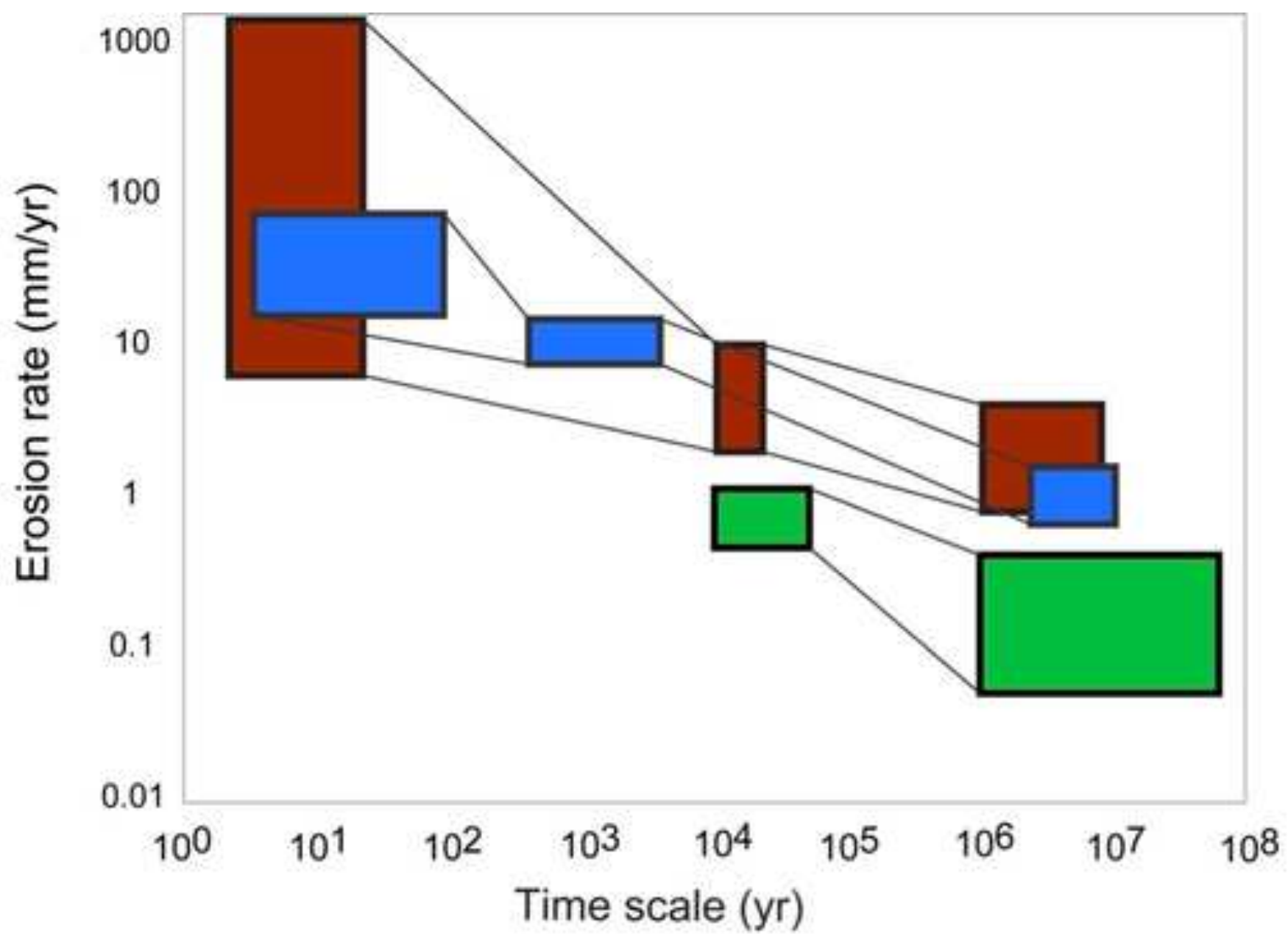

$\square$ Alaskan glaciers

$\square$ Patagonian glaciers

$\square$ PNW Coast Mtns

Annual discharge Radiocarbon Cosmogenic Low temperature sediment yields surface thermochronometry exposure age 
A.

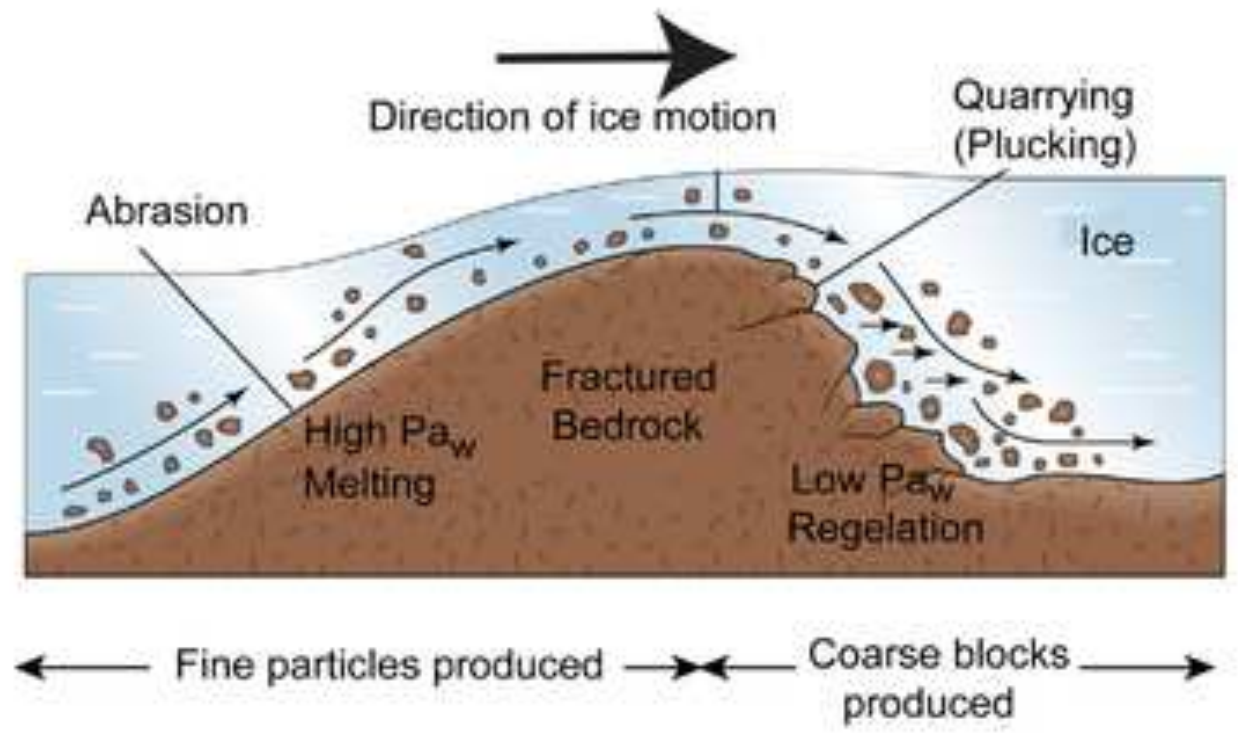

B.

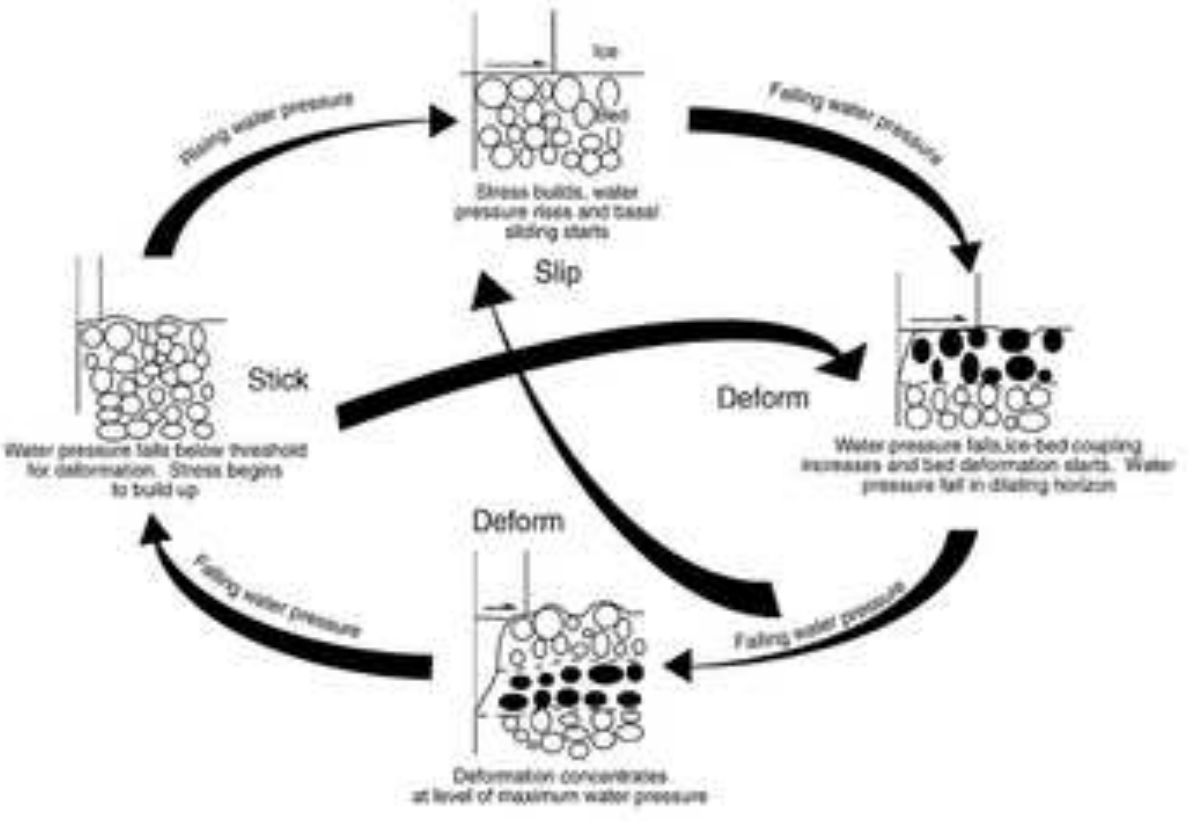




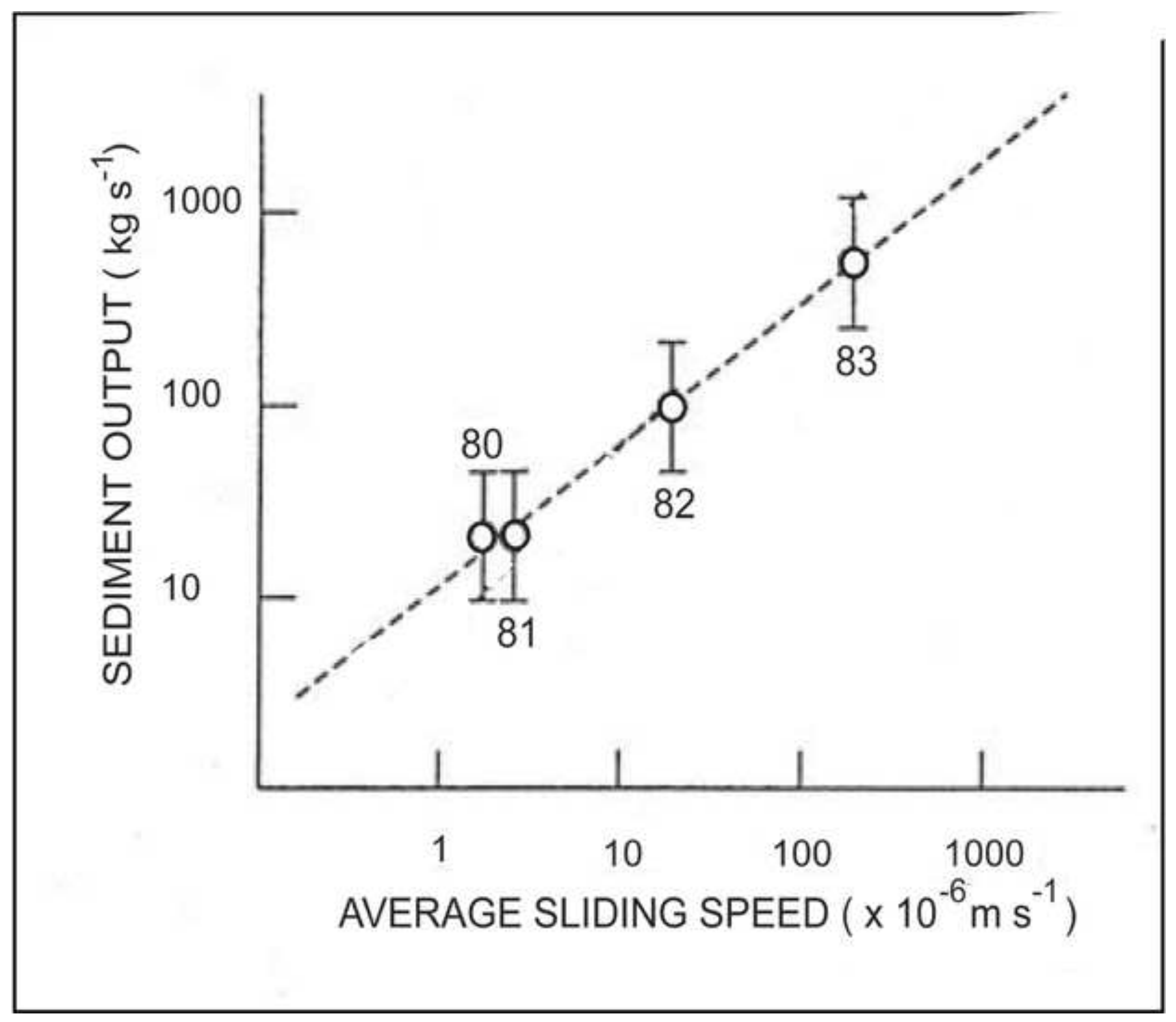




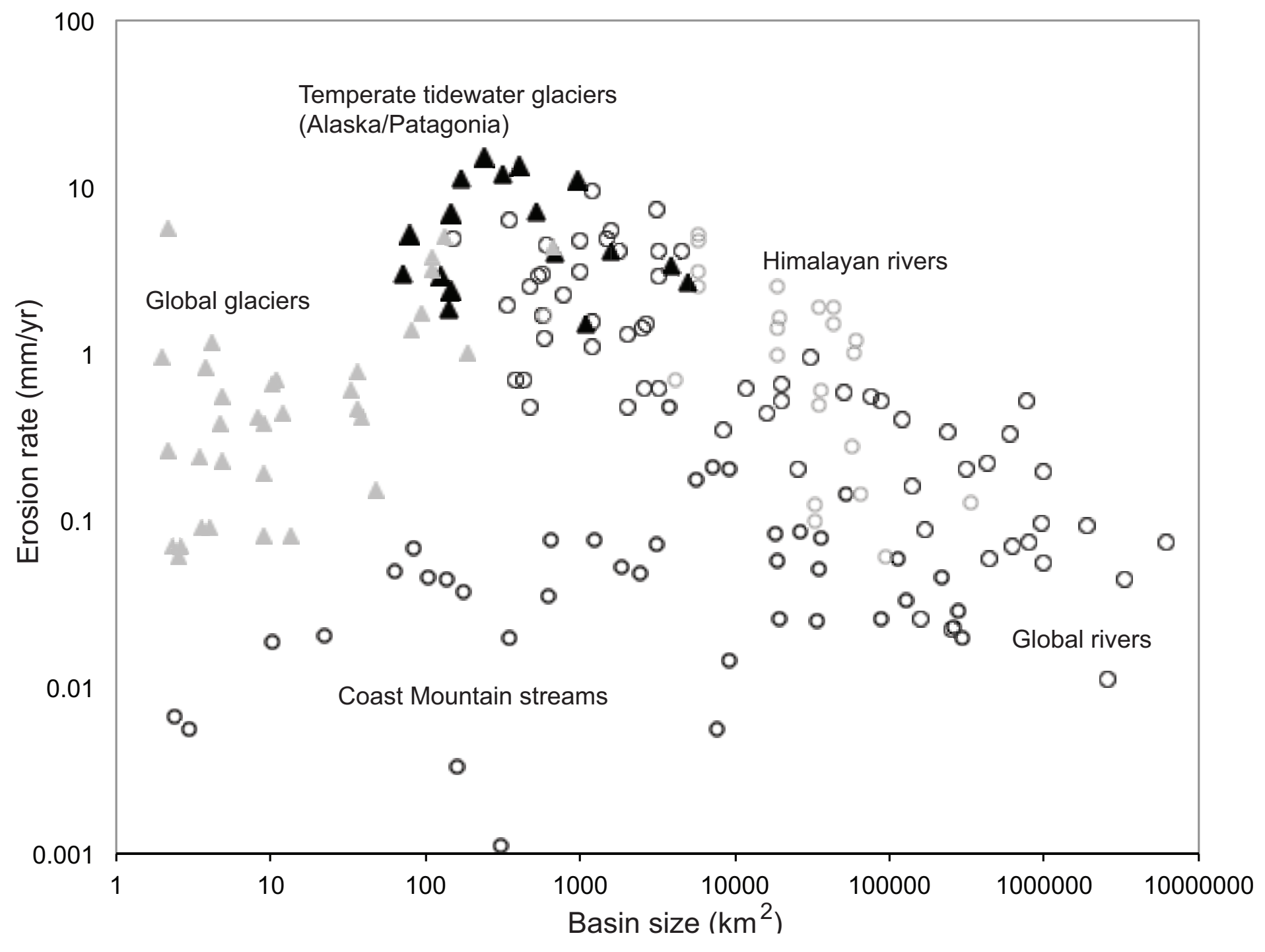




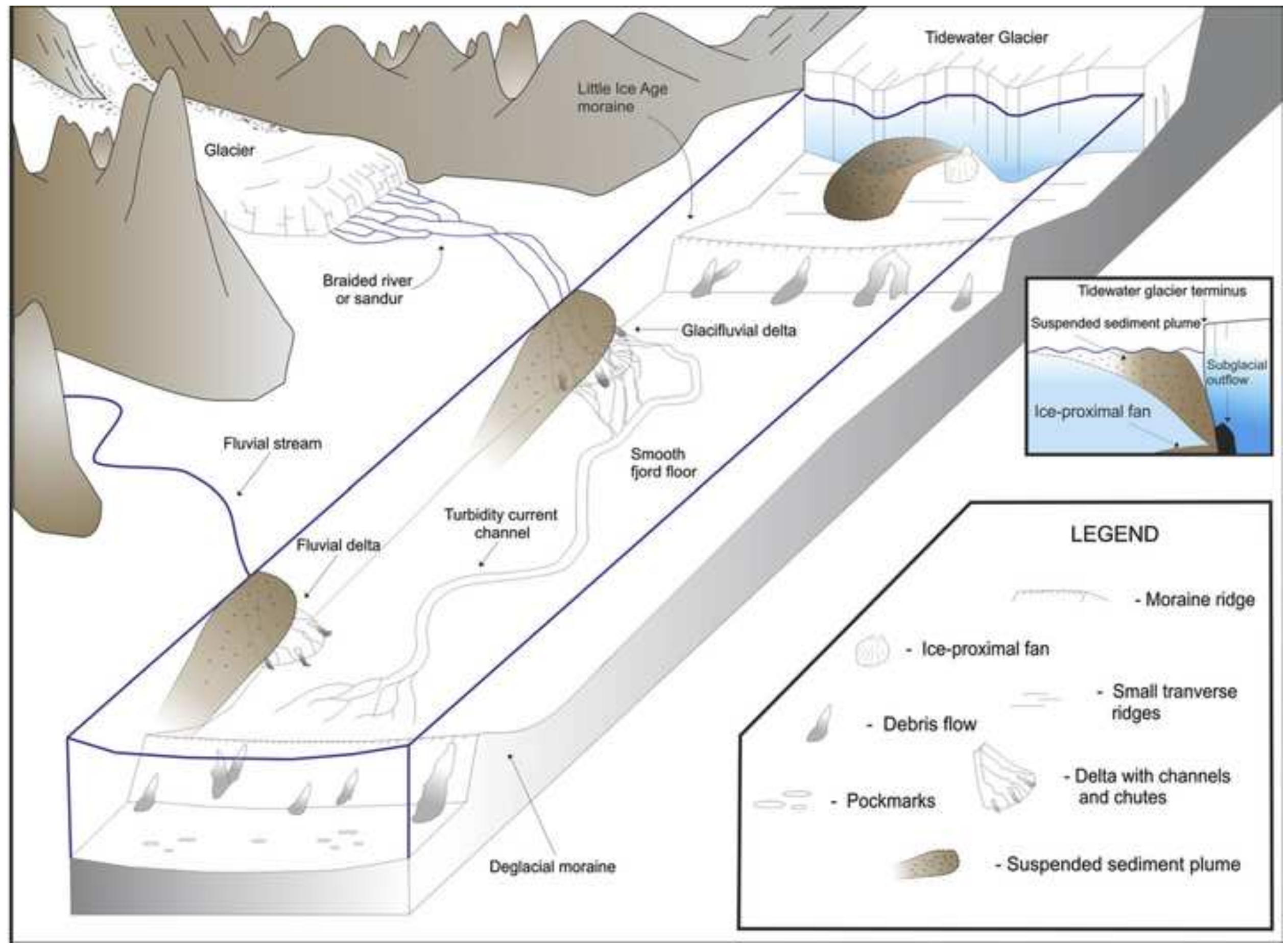



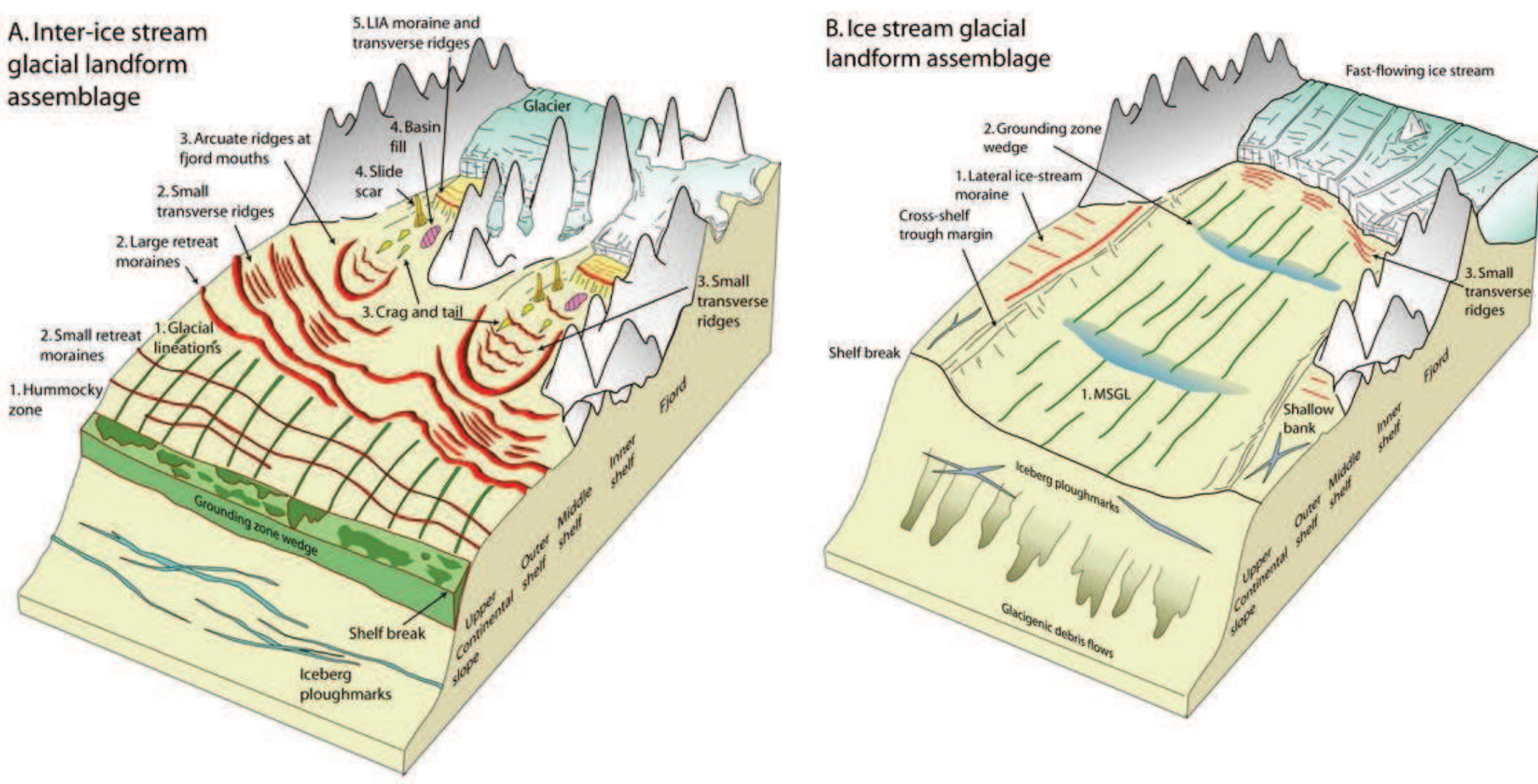


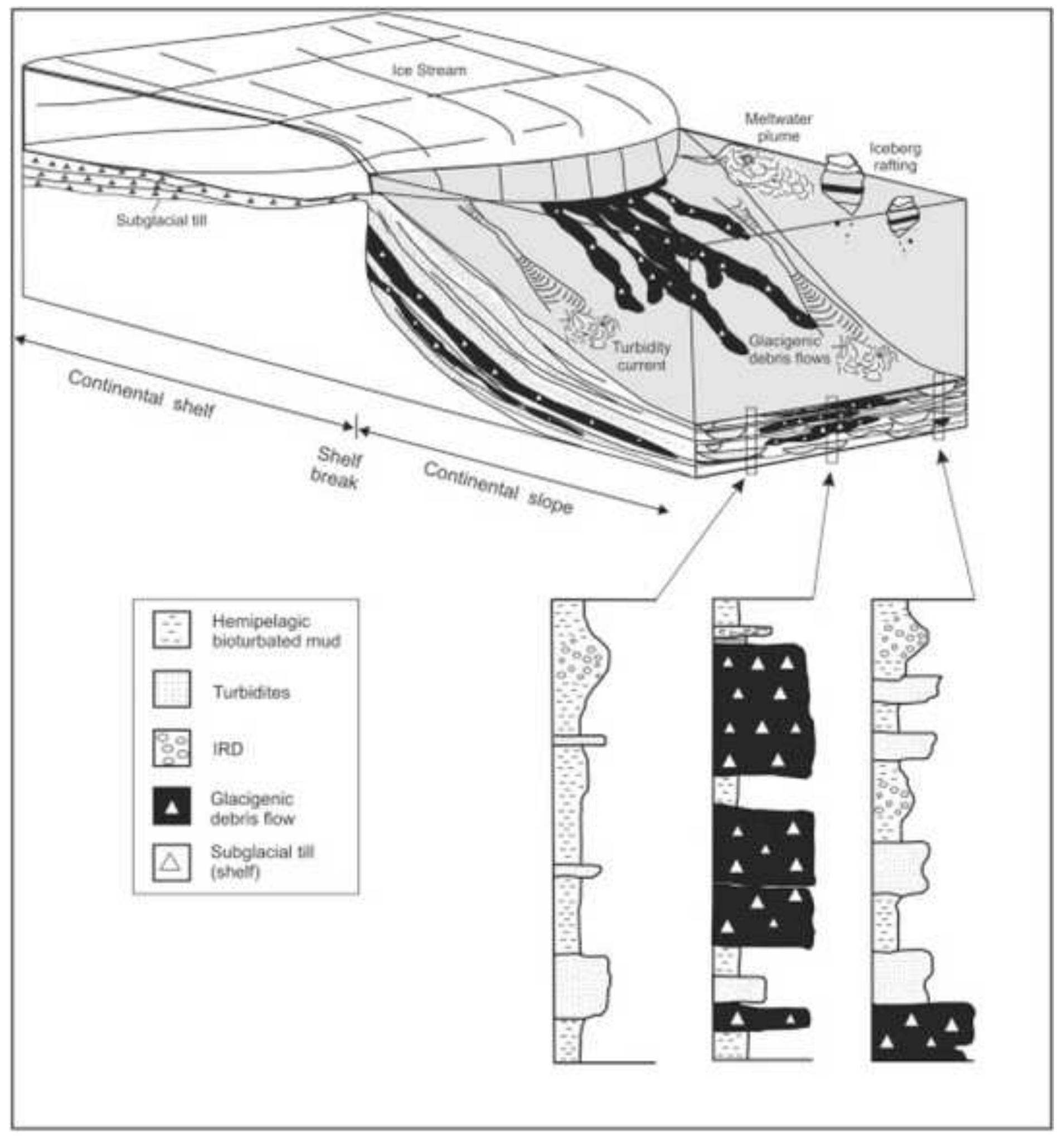




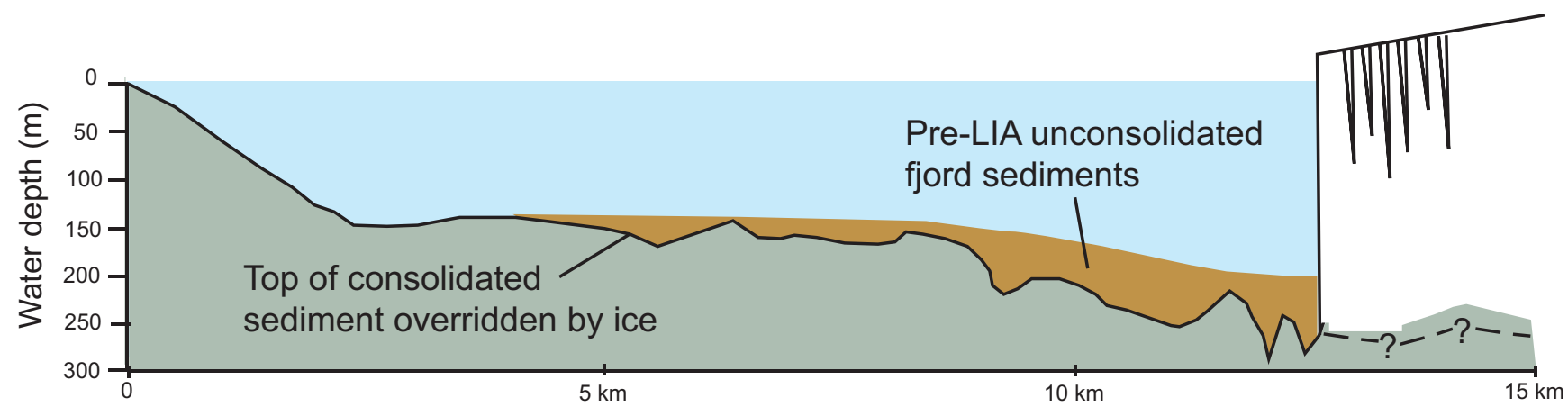

Pre-LIA

extent

-1675 AD

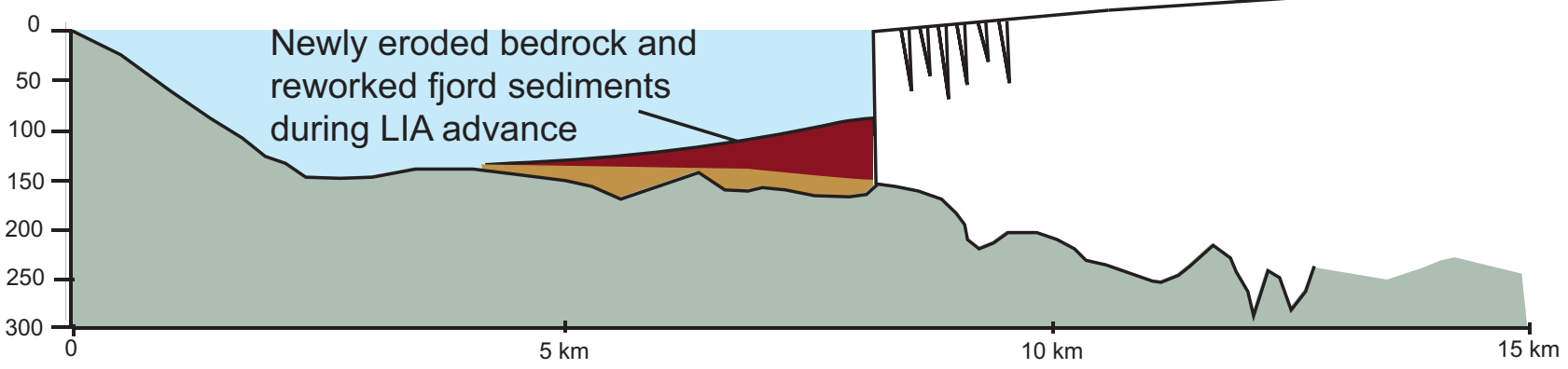

LIA Advance

1675-1875 AD

LIA maximum extent

1875-1900 AD
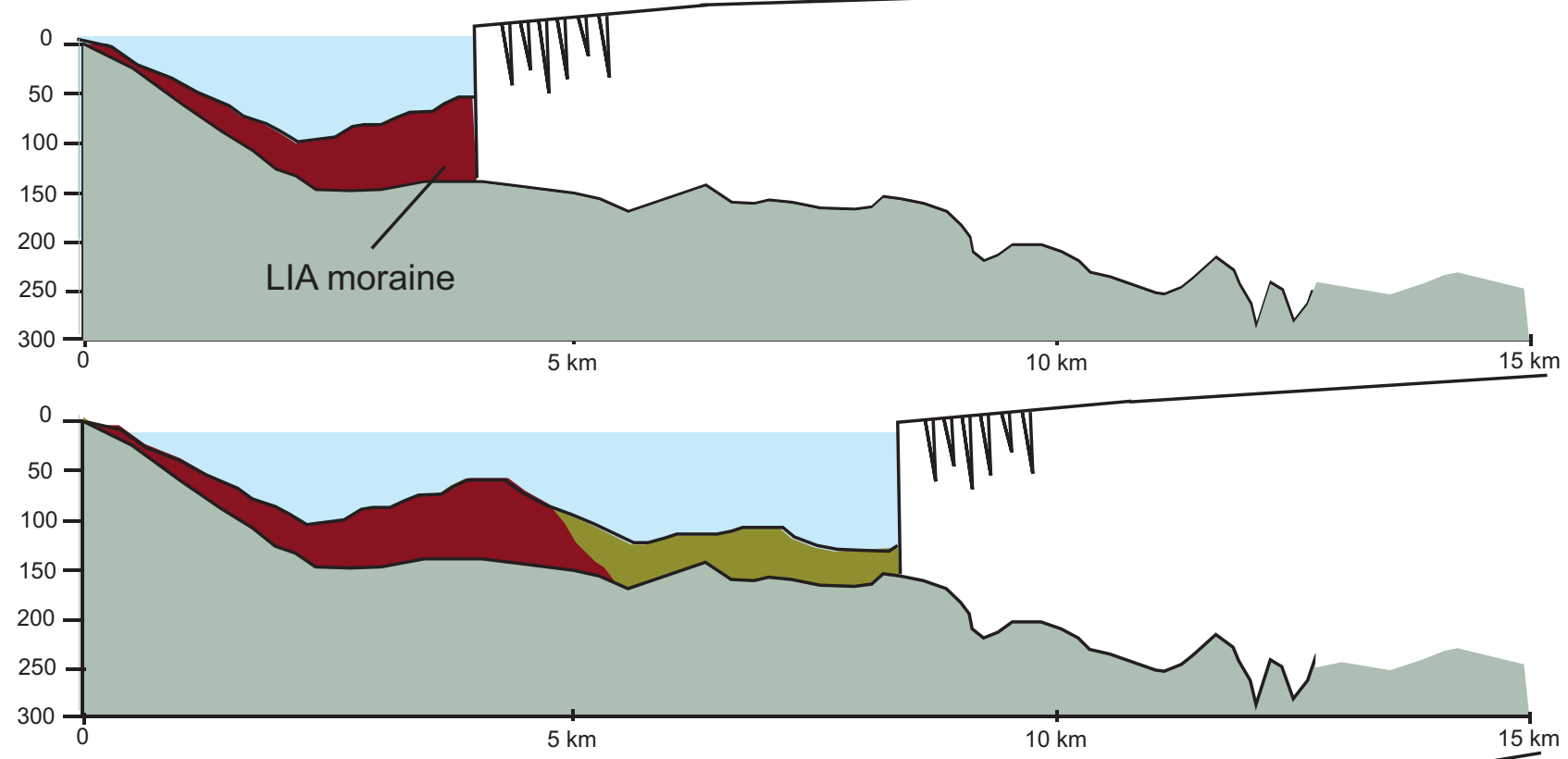

20th century retreat

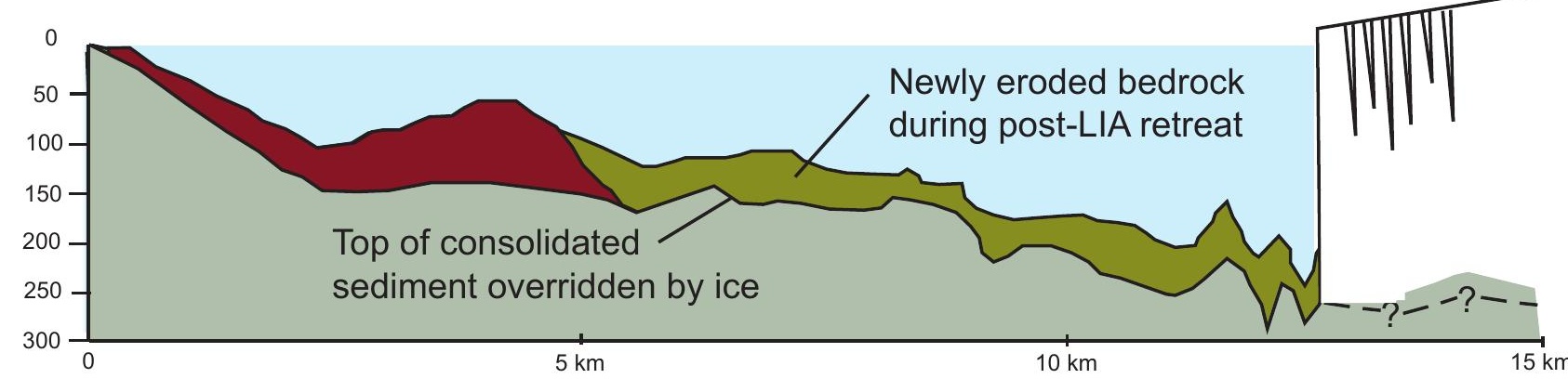


(A) Vancouver Island, western Canada continental slope

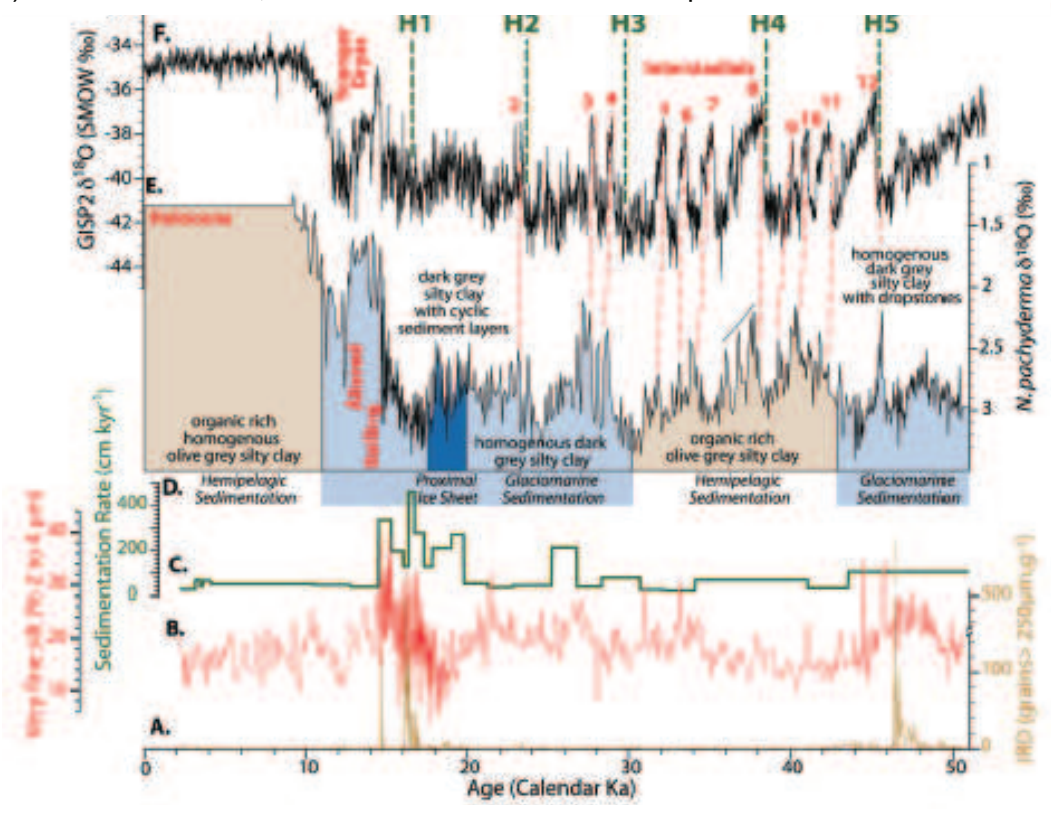

(B) Scoresby Sund, East Greenland continental slope

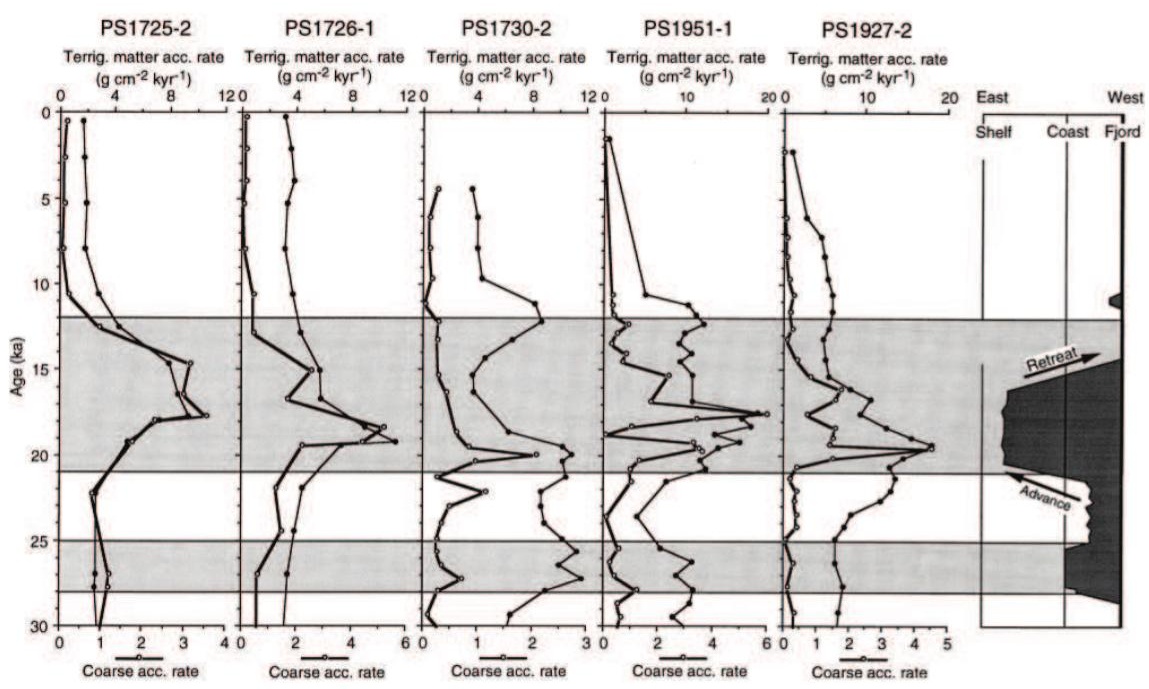



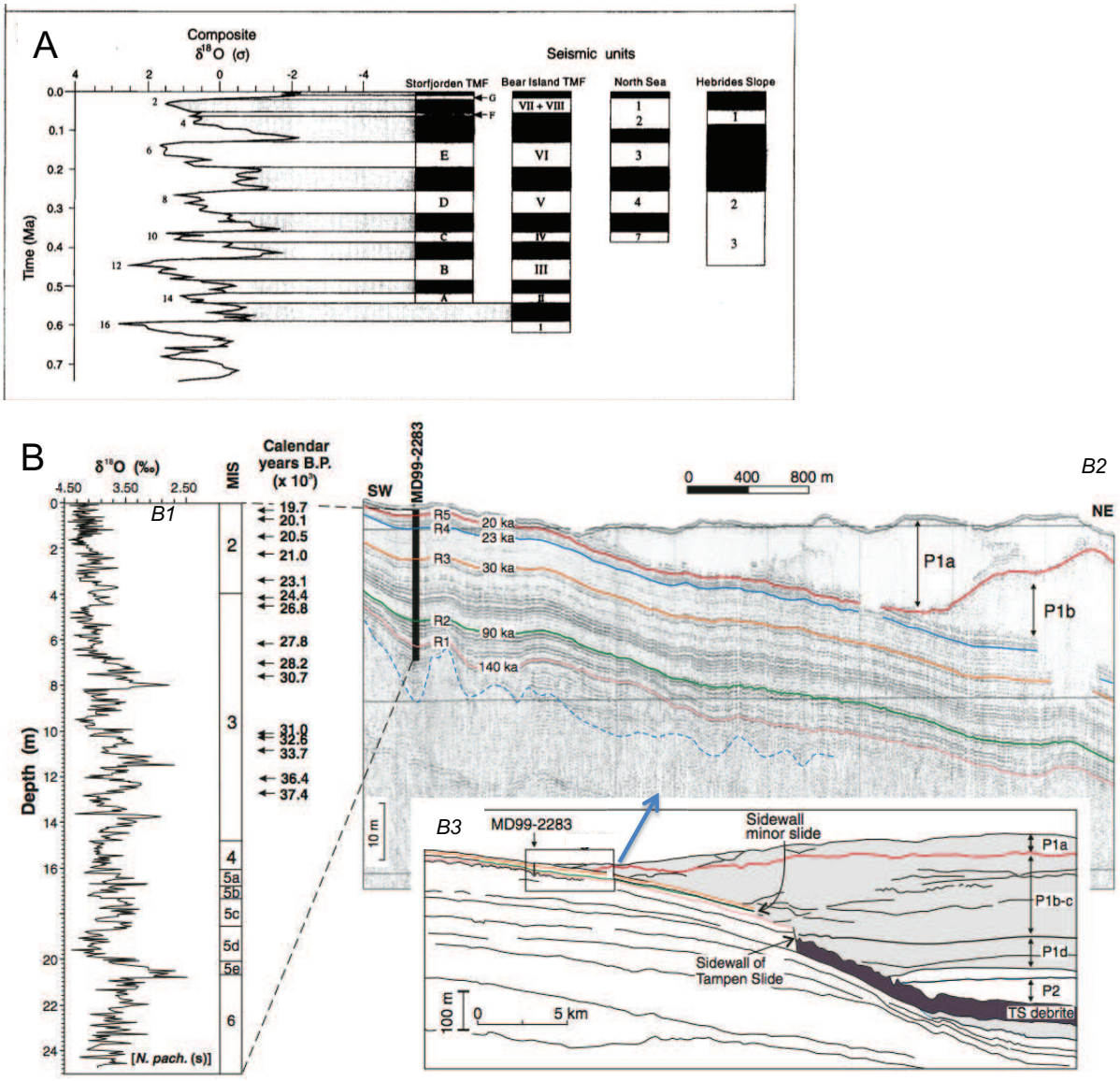
(a) Partially open bay

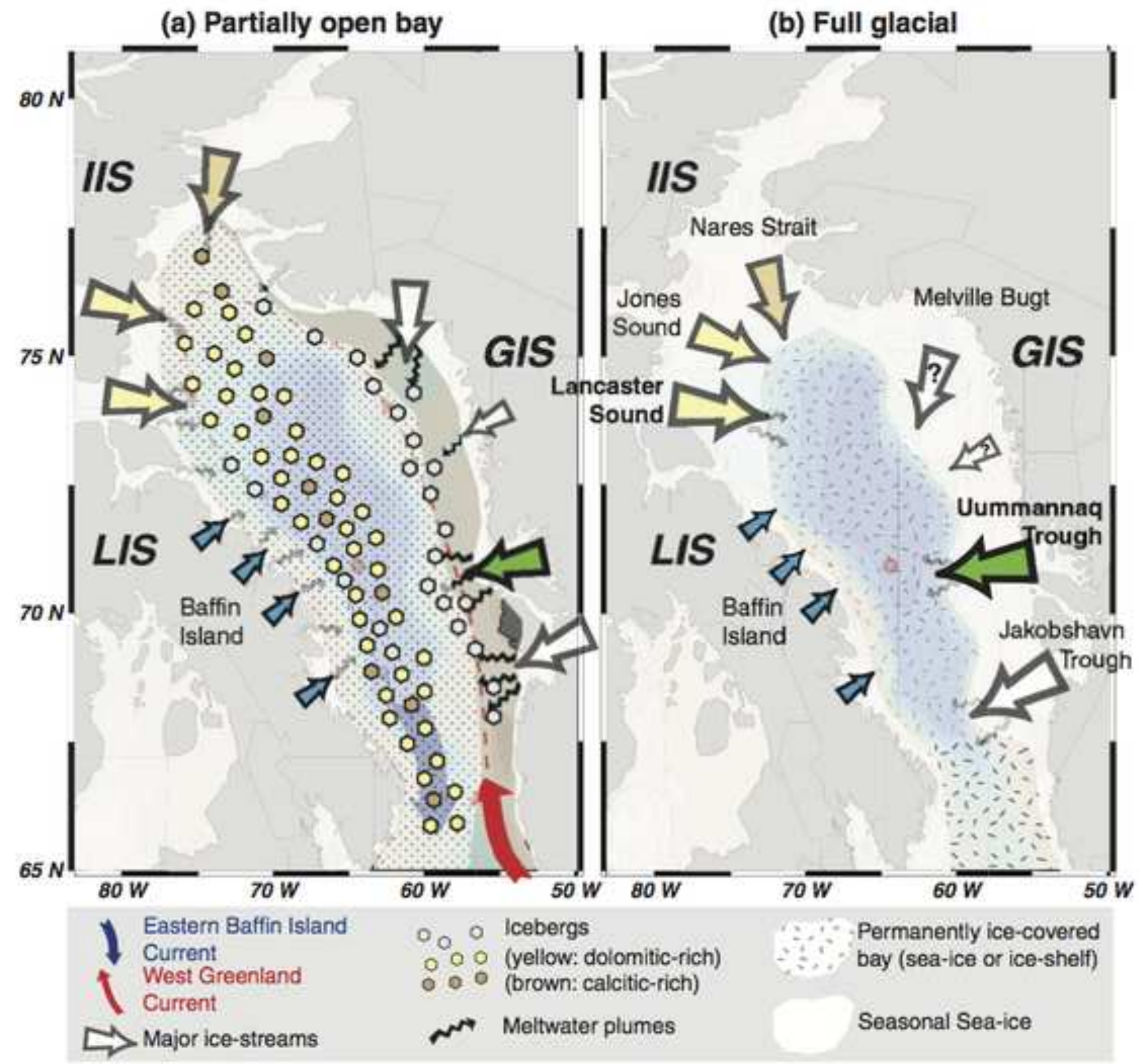

(b) Full glacial 
Marine oxygen isotope stages

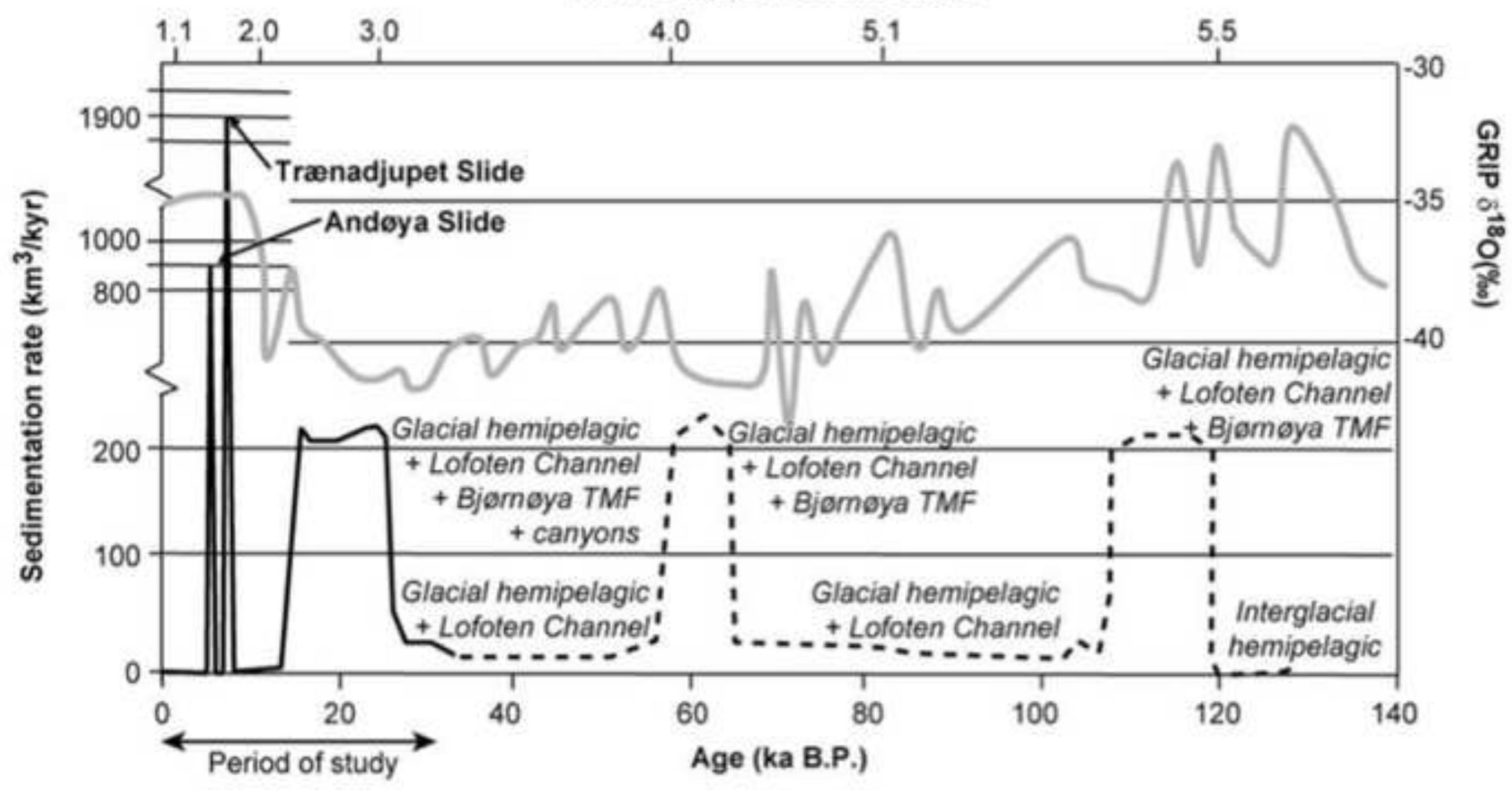



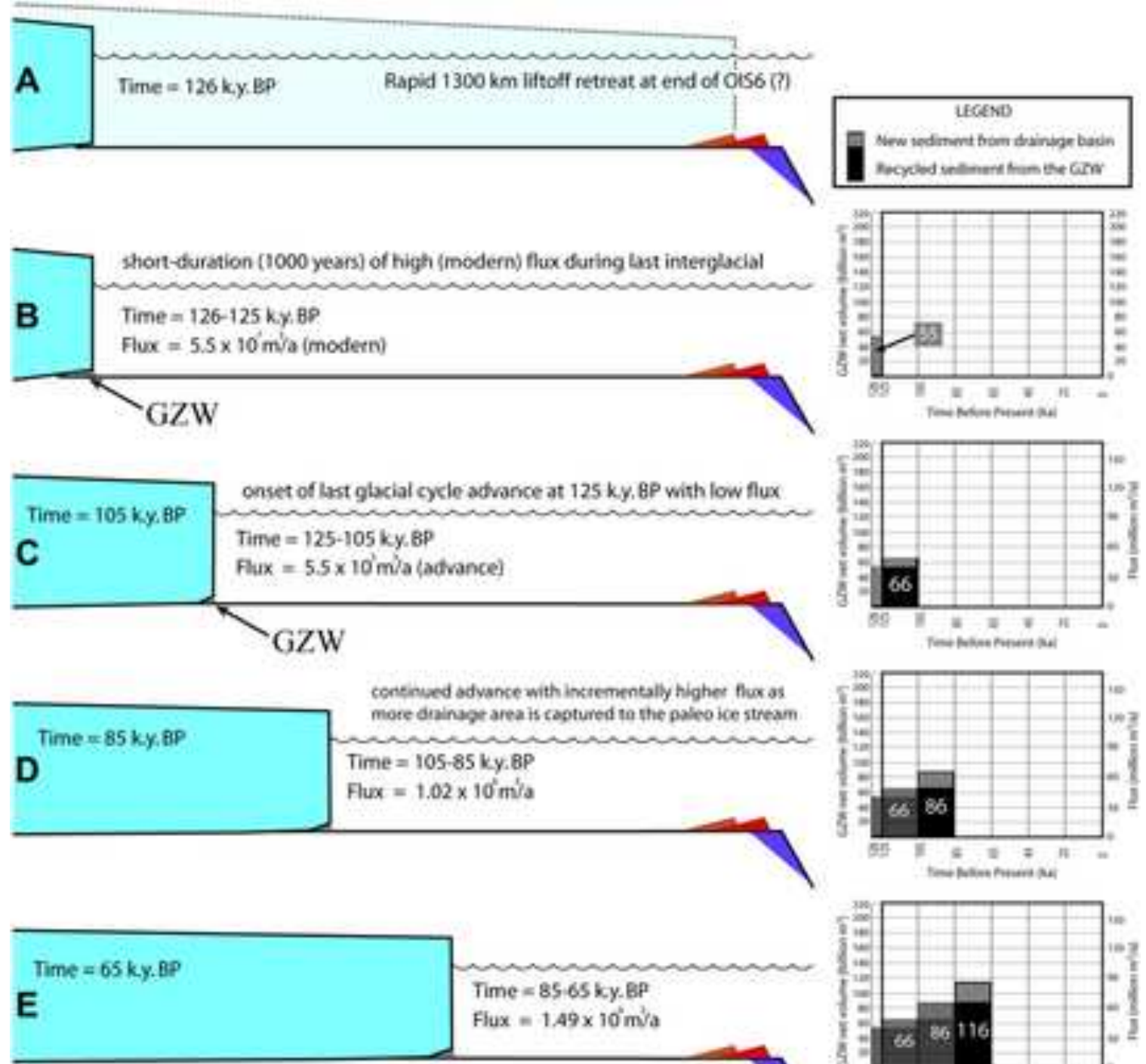

Time $=85.65 \mathrm{ky}$. BP

Flux $=1.49 \times 10^{\prime} \mathrm{m} / \mathrm{a}$
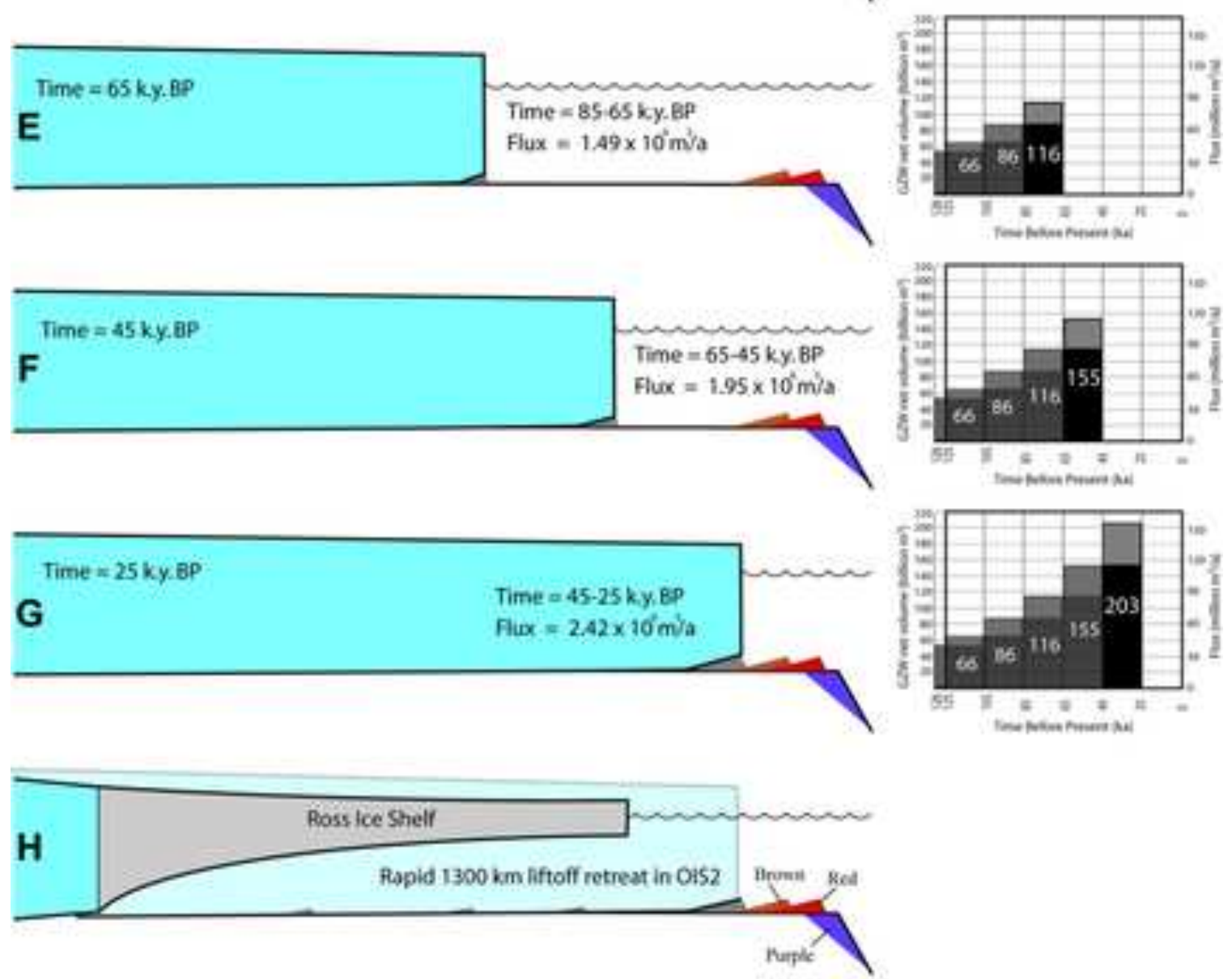

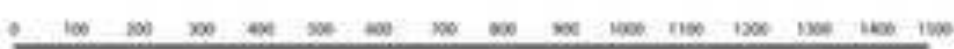

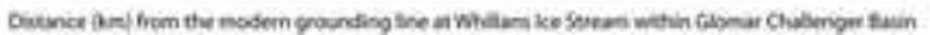


Jaeger\&Koppes_FinalFig18
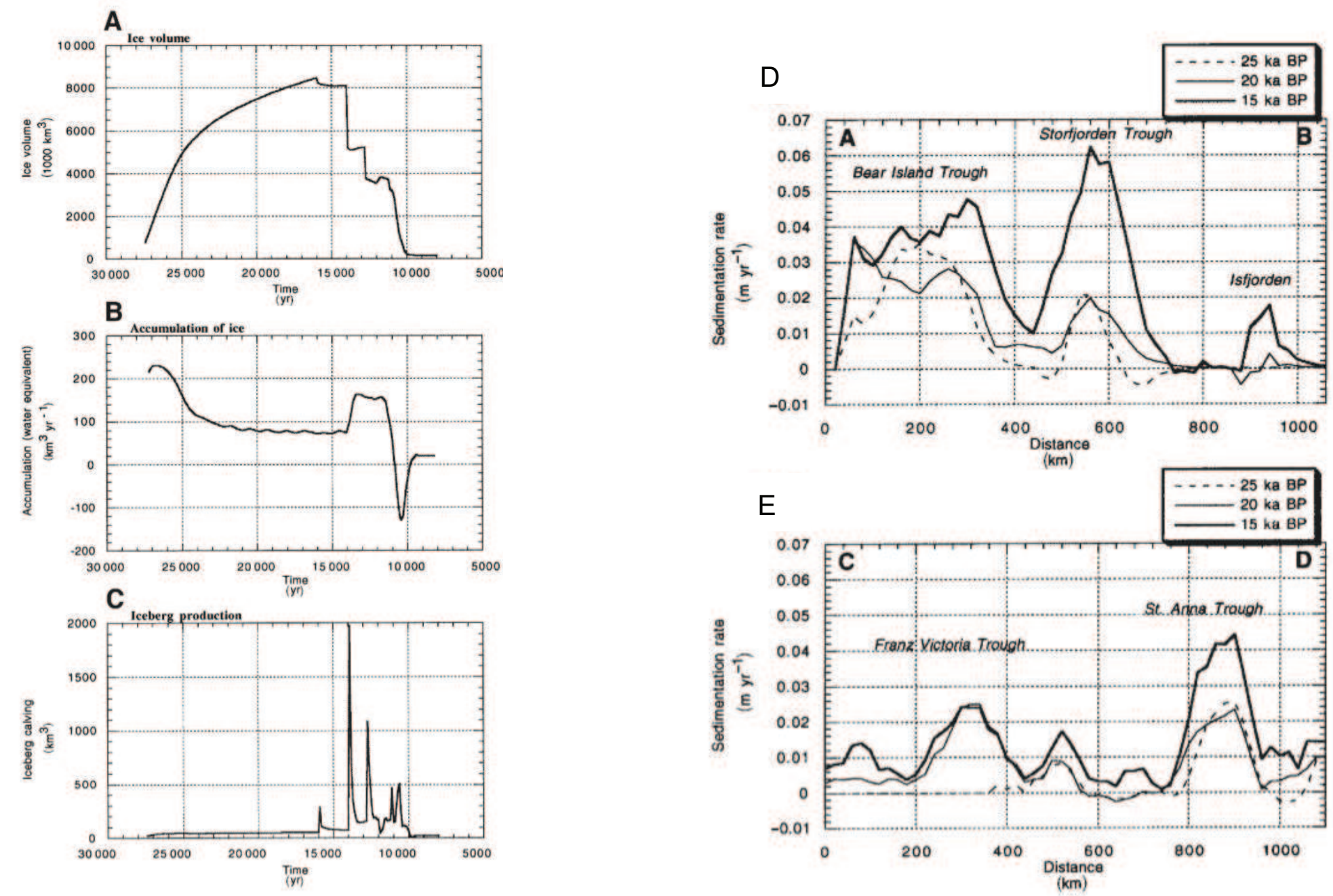